\title{
Supporting Information For: Palladium-Catalyzed Reductive Coupling of Styrenes and Organostannanes under Aerobic Conditions
}

\author{
Keith M. Gligorich, Sarah A. Cummings, and Matthew S. Sigman \\ Department of Chemistry, University of Utah, 315 S. 1400 E. Salt Lake City, UT 84112, USA \\ E-mail: sigman@chem.utah.edu
}

\section{Table of Contents}

$\begin{array}{ll}\text { S1 } & \text { General Considerations } \\ \text { S2 } & \text { Procedure for the Initial Identification of 3a and 4. } \\ \text { S2-S3 } & \text { Optimization for the Reductive Coupling Product Procedures (Table 1) } \\ \text { S3-S4 } & \text { Time Course of the Reductive Coupling Reaction without } \mathrm{MnO}_{2} \\ \text { S4 } & \text { Synthesis of (-)-sparteine- } N \text {-oxide } \\ \text { S4-S5 } & \text { ESI-MS Analysis of the Reductive Coupling Reaction Mixtures } \\ \text { S5-S6 } & \text { Synthesis of Styrene Derivatives } \\ \text { S6-S7 } & \text { Synthesis of Organostannane Reagents } \\ \text { S7-S10 } & \text { General Reductive Coupling Procedure for Preparation of 3a-3k } \\ \text { S11 } & \text { Reductive Coupling Deuterium Labeling Experiment Procedures } \\ \text { S12-S17 } & \text { Reductive Coupling Deuterium Labeling Data \& Calculations } \\ \text { S17-S18 } & \text { Reductive Coupling of Diene 6 } \\ \text { S18 } & \text { Optical Rotation Data } \\ \text { S19 } & \text { References } \\ \text { S20-S21 } & \text { NMR Spectra for the Deuterium Labeling Experiments } \\ \text { S22-S48 } & \text { NMR Spectra }\end{array}$

General Considerations: 2-propanol was dried by refluxing over calcium oxide for $12 \mathrm{~h}$ followed by fractional distillation. THF was dried by distilling from sodium benzophenone ketyl. $\mathrm{CH}_{2} \mathrm{Cl}_{2}$ and triethylamine (TEA) were dried by distilling from calcium hydride. The $3 \AA \AA$ molecular sieves ( $3 \AA$ MS) were powdered and activated by heating with a Bunsen burner while under vacuum. Unless noted, all styrenes and $\mathrm{MnO}_{2}$ were purchased from Aldrich or Acros. Styrenes were purified by passing through a small plug of activated alumina. $\mathrm{Bu}_{3} \mathrm{SnCl}$ and $\mathrm{PhSnBu}_{3}$ were purchased from Gelest Inc. Palladium ${ }^{\mathrm{II}}$ chloride was purchased from Pressure Chemicals. $\operatorname{Pd}[(-)$-sparteine $] \mathrm{Cl}_{2}$ was synthesized according to a previously reported procedure. ${ }^{1}(-)$-sparteine was prepared from $(-)$-sparteine sulfate pentahydrate (purchased from Acros) according to a previously reported procedure. ${ }^{2}{ }^{1} \mathrm{H}-\mathrm{NMR}$ spectra were obtained at $400 \mathrm{MHz}$ or $300 \mathrm{MHz}$, chemical shifts are reported in ppm, and referenced to the $\mathrm{CHCl}_{3}$ singlet at $7.27 \mathrm{ppm} .{ }^{13} \mathrm{C}-\mathrm{NMR}$ spectra were obtained at $100 \mathrm{MHz}$ or $75 \mathrm{MHz}$ and referenced to the center line of the $\mathrm{CDCl}_{3}$ triplet at 77.2 ppm. Flash chromatography was performed either using EM reagent silica 60 (230-400 mesh) or GFS Chemicals activated alumina Brockmann 1. All melting points are uncorrected and were recorded on an electrothermal melting point apparatus. IR spectra were recorded using a FTIR instrument and GC/MS were obtained with a HP 5890 (EI) 50:1 split using a DB-5 column. HRMS were obtained with either an ESI or APCI source with an Agilent LCTOF. GC separations were performed with an HP6890 GC with a flame ionization detector equipped with a DB-5 column using a 50:1 split. Optical rotations were obtained (Na D line) using a Perkin Elmer Model 343 Polarimeter fitted with a micro cell with a $1 \mathrm{dm}$ path length. Caution should be taken when heating flammable solvents in the presence of $\mathrm{O}_{2}$. 
Procedure Used for the Initial Identification of the Reductive Coupling (3a) and Oxidative Heck (4) Products: To a flame dried $100 \mathrm{~mL}$ Schlenk flask equipped with a stir bar, was added $10.3 \mathrm{mg} \operatorname{Pd}[(-)-$ sparteine $] \mathrm{Cl}_{2}$ ( $0.0250 \mathrm{mmol}, 0.0250$ equiv. $), 10.1 \mathrm{mg}$ of $\mathrm{CuCl}_{2}(0.0750 \mathrm{mmol}, 0.0750$ equiv. $), 500 \mathrm{mg}$ of freshly activated $3 \AA \mathrm{MS}$, and $9.20 \mathrm{~mL}$ of 2-propanol. A three-way joint fitted with a balloon of $\mathrm{O}_{2}$ was installed on the flask. The flask was evacuated via water aspiration and refilled with oxygen three times and the mixture was stirred vigorously for ca. 20 minutes at room temperature under $\mathrm{O}_{2}$. To the reaction mixture was added $0.800 \mathrm{~mL}$ of a $1.25 \mathrm{M}$ solution of 4-methylstyrene (1a) $(1.00 \mathrm{mmol}, 1.00$ equiv.) in 2propanol dropwise via a syringe over 5 minutes and $425 \mu \mathrm{L}$ of $\mathrm{PhSnBu}_{3}(1.30 \mathrm{mmol}, 1.30$ equiv.) was added dropwise over 5 minutes. The reaction mixture was stirred vigorously under a balloon of $\mathrm{O}_{2}$. After $40 \mathrm{~h}, 10.0 \mathrm{~mL}$ of a $1.00 \mathrm{M}$ solution of aqueous $\mathrm{NaOH}$ was added to the reaction mixture and was stirred for $1 \mathrm{~h}^{3}{ }^{3}$ The mixture was filtered through Whatman filter paper, rinsed with ca. $10.0 \mathrm{~mL}$ of $\mathrm{Et}_{2} \mathrm{O}$, and was transferred to a separatory funnel. The aq. layer was extracted three times with $20.0 \mathrm{~mL} \mathrm{of} \mathrm{Et}_{2} \mathrm{O}$, all of the organic extracts were combined, washed with $60.0 \mathrm{~mL}$ of brine, and dried over $\mathrm{MgSO}_{4}$. The mixture was filtered and the solvent was removed in vacuo. The products were purified via silica-gel column chromatography by eluting with 0 to $4 \% \mathrm{Et}_{2} \mathrm{O}$ /hexanes. The ${ }^{1} \mathrm{H}$-NMR spectra for $3 \mathrm{a}^{4}$ and $\mathbf{4}^{5}$ were compared to previously reported spectra. Both products were analyzed by GC-MS to obtain their retention times, which were used in the optimization for the reductive coupling product (3a).

Optimization for the Reductive Coupling Product Procedures (Table 1): (Entry 1) To an oven dried $10 \mathrm{~mL}$ Schlenk flask equipped with a stir bar, was added $2.00 \mathrm{mg}$ of $\mathrm{CuCl}_{2}(0.0150 \mathrm{mmol}, 0.0750$ equiv.), $0.900 \mathrm{~mL}$ of 2-propanol, $0.100 \mathrm{~mL}$ of a $2.00 \mathrm{M}$ solution of 4-methylstyrene (1a) $(0.200 \mathrm{mmol}, 1.00$ equiv.) in 2-propanol, which contained ca. $1 \%$ undecane as an internal standard, and $98.0 \mu \mathrm{L}$ of $\mathrm{PhSnBu}_{3}$ ( $0.300 \mathrm{mmol}, 1.50$ equiv.). The flask was installed on a 4-neck flask equipped with condensers (repeated three more times to perform four reactions at once) and a three-way joint fitted with a balloon of $\mathrm{O}_{2}$ was installed on the top of the 4-neck flask. The flask was evacuated via water aspiration and refilled with oxygen three times and the mixture was stirred vigorously for ca. 20 minutes at room temperature under $\mathrm{O}_{2}$. The Schlenk flask was removed from the 4-neck flask and to the reaction mixture, was added $2.10 \mathrm{mg}$ of $\operatorname{Pd}[(-)$-sparteine $] \mathrm{Cl}_{2}(0.00500 \mathrm{mmol}, 0.0250$ equiv.). The flask was reinstalled on the 4 -neck flask and was evacuated via water aspiration and refilled with oxygen three times. The reaction mixture was stirred vigorously under a balloon of $\mathrm{O}_{2}$ at ambient temperature for $20 \mathrm{~h}$ and was orange in color. A small aliquot of the $2.00 \mathrm{M}$ solution of 1a with, undecane as the internal standard, was analyzed by GC and used to calculate the conversion of the substrate. After $20 \mathrm{~h}$, a $50 \mu \mathrm{L}$ aliquot of the reaction mixture was removed and filtered through a small plug of silica eluting with EtOAc. The mixture was analyzed by GC and both the conversion of the substrate was calculated and the GC yields for the products were calculated using a correction factor $\left({ }^{1} \mathrm{H}-\mathrm{NMR}\right.$ was used to measure the response factor to account for varying detector response).

- Entry 2: The same procedure as described above for entry 1 was used except no $\mathrm{CuCl}_{2}$ was added.

- Entry 3: The same procedure as described for entry 1 was used except no $\mathrm{CuCl}_{2}$ was added and $0.700 \mathrm{~mL}$ of 2-propanol and $0.200 \mathrm{~mL}$ of a $0.400 \mathrm{M}$ solution of (-)-sparteine $(0.080 \mathrm{mmol}$, 0.400 equiv.) in 2-propanol were added at the same time the solution of $1 \mathbf{a}$ and $\mathrm{PhSnBu}_{3}$ were added.

- Entry 4: The same procedure was used as entry 3 except 5 minutes after the $\operatorname{Pd}[(-)-$ sparteine $] \mathrm{Cl}_{2}$ was added and the flask was filled/purged with $\mathrm{O}_{2}$, the reaction mixture was heated to $60^{\circ} \mathrm{C}$ in an oil bath and vigorously stirred for $20 \mathrm{~h}$.

- Entry 5: The same procedure was used as entry 4, except $0.100 \mathrm{~mL}$ of a $0.400 \mathrm{M}$ solution of (-)-sparteine $(0.0400 \mathrm{mmol}, 0.200$ equiv. $)$ in 2-propanol and $0.100 \mathrm{~mL}$ of a $0.400 \mathrm{M}$ solution of (-)-sparteine- $N$-oxide $(0.0400 \mathrm{mmol}, 0.200$ equiv.) in 2-propanol were added at the same time the solution of $1 \mathrm{a}$ and $\mathrm{PhSnBu}_{3}$ were added. For the synthesis of (-)-sparteine- $\mathrm{N}$-oxide see below.

- Entry 6: The same procedure was used as entry 4, except $0.600 \mathrm{~mL}$ of 2-propanol and $0.100 \mathrm{~mL}$ of a $0.400 \mathrm{M}$ solution of (-)-sparteine- $\mathrm{N}$-oxide $(0.0400 \mathrm{mmol}, 0.200$ equiv. $)$ in 2propanol were added at the same time the solution of $1 \mathbf{a}$ and $\mathrm{PhSnBu}_{3}$ were added. 
- Entry 7: The same procedure was used as entry 4, except $13.0 \mathrm{mg}$ of $\mathrm{MnO}_{2}(0.150 \mathrm{mmol}$, 0.750 equiv.) was initially added.

- Entry 8: The same procedure was used as entry 6, except $13.0 \mathrm{mg}$ of $\mathrm{MnO}_{2}(0.150 \mathrm{mmol}$, 0.750 equiv.) was initially added.

- Entry 9: To an oven dried $100 \mathrm{~mL}$ Schlenk flask equipped with a stir bar, was added $4.30 \mathrm{~mL}$ of 2-propanol, $0.200 \mathrm{~mL}$ of a $2.00 \mathrm{M}$ solution of (-)-sparteine $(0.400 \mathrm{mmol}, 0.400$ equiv. $)$ in 2propanol, $0.500 \mathrm{~mL}$ of a $2.00 \mathrm{M}$ solution of 4-methylstyrene (1a) $(1.00 \mathrm{mmol}, 1.00$ equiv.) in 2-propanol, which contained ca. $1 \%$ undecane as an internal standard, and $490 \mu \mathrm{L}$ of $\mathrm{PhSnBu}_{3}$ ( $1.50 \mathrm{mmol}, 1.50$ equiv.). A condenser was installed on the flask and a three-way joint fitted with a balloon of $\mathrm{O}_{2}$ was installed on the top of the condenser. The flask was evacuated via water aspiration and refilled with oxygen three times and the mixture was stirred vigorously for ca. 20 minutes at room temperature under $\mathrm{O}_{2}$. The flask was removed from the condenser and to the reaction mixture, was added $10.3 \mathrm{mg}$ of $\mathrm{Pd}[(-)$-sparteine $] \mathrm{Cl}_{2} \quad(0.0250 \mathrm{mmol}$, 0.0250 equiv.). The condenser was reinstalled on flask and the flask was evacuated via water aspiration and refilled with oxygen three times. The reaction mixture was stirred vigorously under a balloon of $\mathrm{O}_{2}$ at ambient temperature for 5 minutes. The mixture was heated to $60{ }^{\circ} \mathrm{C}$ in an oil bath and was stirred vigorously for $20 \mathrm{~h}$. The reaction mixture was analyzed by GC in the same manner as described for entry 1.

- Entry 10: A three-way joint was fitted to the side arm of an oven dried $100 \mathrm{~mL}$ thick-wall glass pressure vessel equipped with a stir bar. $\mathrm{An}_{2}$ tank was connected to the three-way joint and $\mathrm{O}_{2}$ was passed through the vessel. To the vessel, was added $4.30 \mathrm{~mL}$ of 2-propanol, $0.200 \mathrm{~mL}$ of a $2.00 \mathrm{M}$ solution of (-)-sparteine $(0.400 \mathrm{mmol}, 0.400$ equiv.) in 2-propanol, $0.500 \mathrm{~mL}$ of a $2.00 \mathrm{M}$ solution of 4-methylstyrene (1a) $(1.00 \mathrm{mmol}$, 1.00 equiv.) in 2-propanol, which contained ca. $1 \%$ undecane as an internal standard, and $490 \mu \mathrm{L}$ of $\mathrm{PhSnBu}_{3}(1.50 \mathrm{mmol}$, 1.50 equiv.). The vessel was sealed, pressurized to $25 \mathrm{psi}$, evacuated via water aspiration, and re-pressurized to $25 \mathrm{psi} \mathrm{O}_{2}$. This procedure was repeated three times. The vessel was sealed and the mixture was stirred vigorously for ca. $20 \mathrm{~min}$ at room temperature at $25 \mathrm{psi} \mathrm{O}_{2}$. The vessel was opened and $\mathrm{O}_{2}$ was passed through the vessel. To the stirred mixture, was added $10.3 \mathrm{mg}$ of $\mathrm{Pd}[(-)$-sparteine $] \mathrm{Cl}_{2}(0.0250 \mathrm{mmol}, 0.0250$ equiv. $)$. The vessel was immediately pressurized to 25 psi $\mathrm{O}_{2}$ and was sealed. The three-way joint was removed and the reaction mixture was stirred vigorously for $5 \mathrm{~min}$ at room temperature. The mixture was then heated to $60{ }^{\circ} \mathrm{C}$ in an oil bath and was stirred vigorously for $20 \mathrm{~h}$. The vessel was removed from the oil bath and cooled to room temperature. The reaction mixture was analyzed by GC in the same manner as described for entry 1.

- Entry 11: The same procedure as entry 10 was used except $65.2 \mathrm{mg}$ of $\mathrm{MnO}_{2}(0.750 \mathrm{mmol}$, 0.750 equiv.) was initially added.

Optimization note: The use of $3 \AA$ molecular sieves did not have an appreciable affect upon the reaction.

Time Course of the Reductive Coupling Reaction without $\mathbf{M n O}_{2}$ : To an oven dried $10 \mathrm{~mL}$ Schlenk flask equipped with a stir bar, was added $1.25 \mathrm{~mL}$ of 2-propanol, $0.150 \mathrm{~mL}$ of a $0.800 \mathrm{M}$ solution of (-)sparteine ( $0.120 \mathrm{mmol}, 0.400$ equiv.) in 2-propanol, $0.100 \mathrm{~mL}$ of a $3.00 \mathrm{M}$ solution of 4-methylstyrene (1a) ( $0.300 \mathrm{mmol}, 1.00$ equiv.) in 2-propanol, which contained ca. $1 \%$ undecane as an internal standard, and $127 \mu \mathrm{L}$ of $\mathrm{PhSnBu}_{3}(0.390 \mathrm{mmol}, 1.30$ equiv.). A condenser was installed on the flask and a three-way joint fitted with a balloon of $\mathrm{O}_{2}$ was installed on the top of the condenser. The flask was evacuated via water aspiration and refilled with oxygen three times and the mixture was stirred vigorously for ca. 20 minutes at room temperature under $\mathrm{O}_{2}$. The flask was removed from the condenser and to the reaction mixture, was added $3.10 \mathrm{mg}$ of $\mathrm{Pd}[(-)$-sparteine $] \mathrm{Cl}_{2}(0.00750 \mathrm{mmol}, 0.0250$ equiv.). The condenser was reinstalled on flask and the flask was evacuated via water aspiration and refilled with oxygen three times. The reaction mixture was stirred vigorously under a balloon of $\mathrm{O}_{2}$ at ambient temperature for 5 minutes. The mixture was heated to $60^{\circ} \mathrm{C}$ in an oil bath and was stirred vigorously for $20 \mathrm{~h}$. The reaction mixture was analyzed by GC at different times in the same manner as described for entry 1 above and the data is plotted below. 


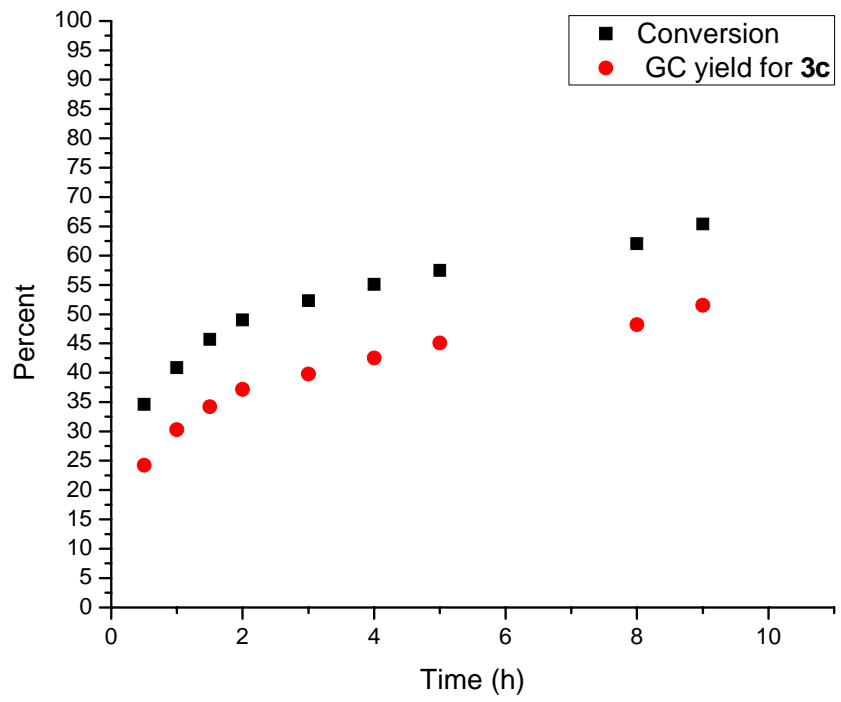

Synthesis of (-)-sparteine- $N$-oxide: ${ }^{6}$ To a $50 \mathrm{~mL}$ round bottom flask equipped with a stir bar, was added $234 \mathrm{mg}$ of (-)-sparteine (1.00 mmol, 1.00 equiv.), $8.00 \mathrm{~mL}$ of $\mathrm{MeOH}$, and $0.943 \mathrm{~mL}$ of $30 \%(\mathrm{v} / \mathrm{v}) \mathrm{H}_{2} \mathrm{O}_{2}$ in water $(8.30 \mathrm{mmol}, 8.30$ equiv.). The flask was sealed and stirred at room temperature for 3 days. To the stirred mixture, was added ca. $20 \mathrm{mg}$ of $10 \mathrm{wt} . \%$ palladium on activated carbon. After $2 \mathrm{~h}$, the mixture was filtered through celite and rinsed with ca. $20 \mathrm{~mL}$ of $\mathrm{Et}_{2} \mathrm{O}$. The solvent was removed in vacuo to produce a yellow oil. To the oil, was added $20 \mathrm{~mL}$ of $\mathrm{CH}_{2} \mathrm{Cl}_{2}$ and the mixture was dried over $\mathrm{Na}_{2} \mathrm{SO}_{4}$ for $2 \mathrm{~h}$. The mixture was filtered and the solvent was removed in vacuo to produce a yellow oil. Trace solvent was removed by high vacuum to yield a white solid. The product was characterized by ESI-MS by dissolving the solid in a 1:1 2-propanol: $\mathrm{H}_{2} \mathrm{O}$ solvent mixture containing 1\% glacial acetic acid and the solution was injected into the instrument with a syringe pump.

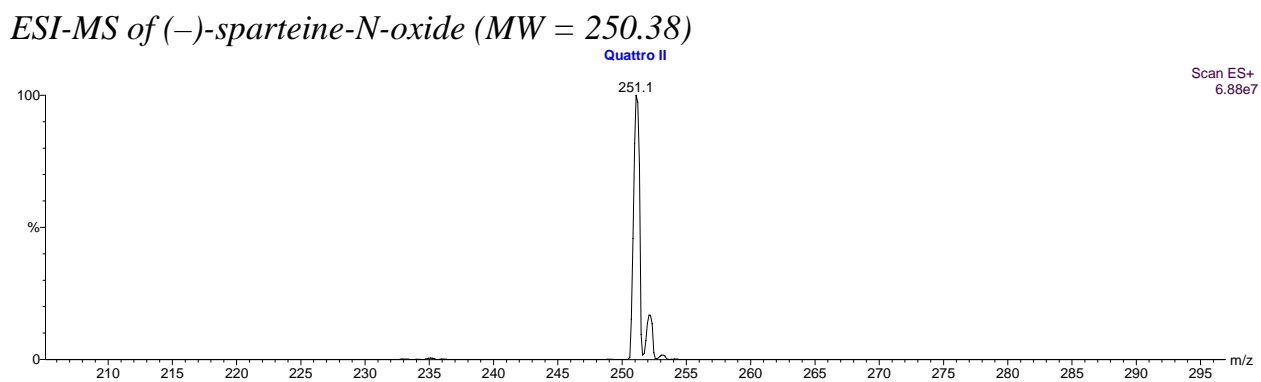

ESI-MS Analysis of the Reductive Coupling Reaction Mixtures without and with $\mathrm{MnO}_{2}$

Experiment performed without $\mathbf{M n O}_{2}$ : After cooling to room temperature, a $20 \mu \mathrm{L}$ aliquot of the reductive coupling reaction mixture, which was performed on $1.0 \mathrm{mmol}$ scale at 25 psi without $\mathrm{MnO}_{2}$ (Table 1, entry 8) was diluted with $480 \mu \mathrm{L}$ of 2-propanol, $500 \mu \mathrm{L} \mathrm{H}_{2} \mathrm{O}$, and $10 \mu \mathrm{L}$ of glacial acetic acid. The solution was injected into the Micromass Quattro II quadrupole ESI-MS instrument with a syringe pump. 
ESI-MS spectrum of the reductive coupling reaction mixture performed without $\mathrm{MnO}_{2}$

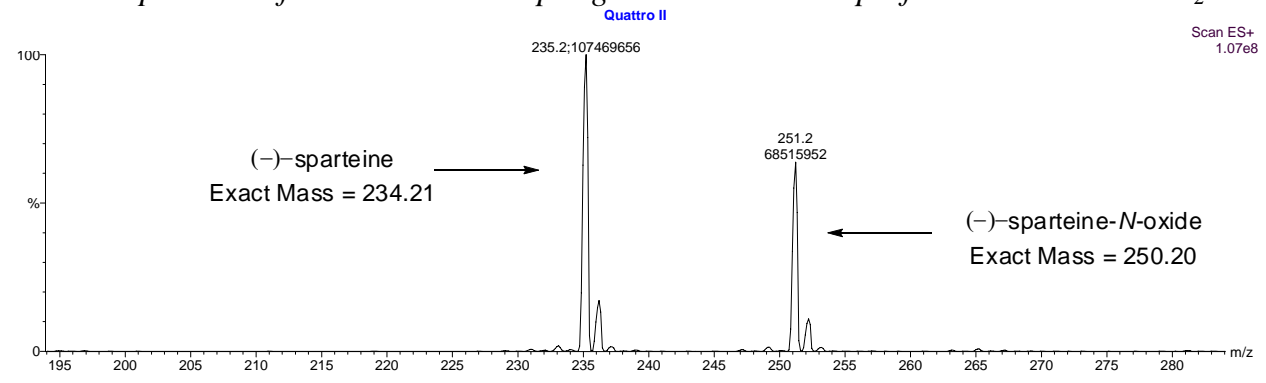

Experiment performed with $\mathbf{M n O}_{2}$ : After cooling the reaction mixture, which was performed on $1.0 \mathrm{mmol}$ scale at $25 \mathrm{psi}$ with $\mathrm{MnO}_{2}$ (Table 1, entry 9), to room temperature, the mixture was filtered through Whatman filter paper to remove the $\mathrm{MnO}_{2}$. A $20 \mu \mathrm{L}$ aliquot of the reaction mixture was diluted with $480 \mu \mathrm{L}$ of 2-propanol, $500 \mu \mathrm{L} \mathrm{H}_{2} \mathrm{O}$, and $10 \mu \mathrm{L}$ of glacial acetic acid. The solution was injected into the Micromass Quattro II quadrupole ESI-MS instrument with a syringe pump using the same flow rate and settings (ie. voltages, gain, etc.) as the experiment performed without $\mathrm{MnO}_{2}$.

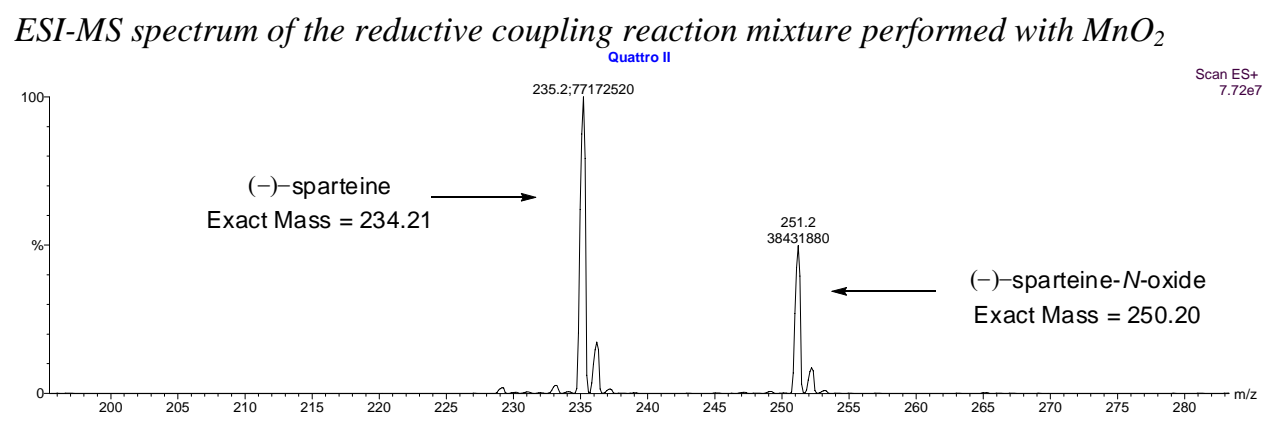

Calculation of the percent difference of (-)-sparteine- $\mathrm{N}$-oxide to (-)-sparteine with and without $\mathrm{MnO}_{2}$

\begin{tabular}{rcc} 
& \multicolumn{2}{c}{ Peak heights from ESI-MS experiments } \\
\hline $\mathrm{No} \mathrm{MnO}_{2}$ & $75 \mathrm{~mol}^{\circ} \mathrm{MnO}_{2}$ \\
\hline$(-)$-sparteine & 107469656 & 77687224 \\
$(-)$-sparteine- $\mathrm{N}$-oxide & 68515952 & 38769100 \\
$\begin{array}{c}(-) \text {-sparteine-N-oxide/ } \\
(-)-\text { sparteine }\end{array}$ & 0.63754 & 0.49904 \\
\hline
\end{tabular}

Percent difference $=[(0.63754 / 0.49904)-1]^{\star} 100=28 \%$

\section{Synthesis of Styrene Derivatives:}

tert-butyl-4-vinylphenylcarbamate (1c): To an oven dried $100 \mathrm{~mL}$ round bottom flask Boc - equipped with a stir bar, was added $1.15 \mathrm{~g} \mathrm{Boc}_{2} \mathrm{O}(5.27 \mathrm{mmol}, 1.15$ equiv.) and $20.0 \mathrm{~mL}$ THF under a $\mathrm{N}_{2}$ atmosphere. A solution of $546 \mathrm{mg}$ of 4-vinylaniline (Oakwood Products Inc.) (4.58 mmol, 1.00 equiv.) in $20 \mathrm{~mL}$ THF was added to the stirred solution of $\mathrm{Boc}_{2} \mathrm{O}$ via syringe, and a dried water condenser was installed on the flask. The mixture was heated to $50{ }^{\circ} \mathrm{C}$ in an oil bath, and stirred under $\mathrm{N}_{2}$ for $12 \mathrm{~h}$. An additional $500 \mathrm{mg} \mathrm{Boc} 2 \mathrm{O}(2.29 \mathrm{mmol}, 0.500$ equiv.) was added, and the reaction was stirred at $50{ }^{\circ} \mathrm{C}$ for another $12 \mathrm{~h}$. The mixture was diluted with $20 \mathrm{~mL} \mathrm{Et}_{2} \mathrm{O}$, washed twice with $50 \mathrm{~mL}$ of sat. aq. $\mathrm{NH}_{4} \mathrm{Cl}$, twice with $50 \mathrm{~mL}$ of $\mathrm{H}_{2} \mathrm{O}$, and once with $50 \mathrm{~mL}$ of brine. The organic extracts were dried over $\mathrm{MgSO}_{4}$, filtered, and concentrated in vacuo. Column chromatography eluting with $4 \% \mathrm{Et}_{2} \mathrm{O} /$ hexanes yielded a mixture of tert-butyl-4-vinylphenylcarbamate (1c) and $\mathrm{Boc}_{2} \mathrm{O}$. The mixture was diluted with $50 \mathrm{~mL} \mathrm{Et} 2 \mathrm{O}$, washed twice with $50 \mathrm{~mL}$ of sat. aq. $\mathrm{NH}_{4} \mathrm{Cl}$, once with $50 \mathrm{~mL}$ of brine, and 
twice with $50 \mathrm{~mL}$ of $1: 1$ aq. $\mathrm{NH}_{4} \mathrm{OH} / \mathrm{H}_{2} \mathrm{O}$. The combined aqueous layers were extracted with $50 \mathrm{~mL}$ of $\mathrm{Et}_{2} \mathrm{O}$ and the organic extracts were washed with $50 \mathrm{~mL}$ of brine, dried with $\mathrm{MgSO}_{4}$, filtered, and the solvent was remove in vacuo. Silica gel flash chromatography, eluting with $4 \% \mathrm{Et}_{2} \mathrm{O} /$ hexanes to $8 \%$ $\mathrm{Et}_{2} \mathrm{O} /$ hexanes, yielded the product as a white solid.

1c, Yield: 62\% (621.5 mg); $\mathrm{R}_{\mathrm{f}}: 0.50 \mathrm{w} / 20 \%$ EtOAc/hexanes (silica); White solid; mp: $84{ }^{\circ} \mathrm{C}$; $\mathrm{IR}(\mathrm{KBr})$ 3376, 2984, 2936, 1754, 1612, 1586, 1523, 1319, 1236, 1160, 1056, 986, 838, 771, 619; ${ }^{1} \mathrm{H}-\mathrm{NMR}$ $\left(300 \mathrm{MHz}, \mathrm{CDCl}_{3}\right) \delta 1.52(\mathrm{~s}, 9 \mathrm{H}), 5.16(\mathrm{dd}, J=1.0 \mathrm{~Hz}, 11.0 \mathrm{~Hz}, 1 \mathrm{H}), 5.65(\mathrm{dd}, J=1.0 \mathrm{~Hz}, 17.6 \mathrm{~Hz}, 1 \mathrm{H})$, 6.49 (br s, $1 \mathrm{H}), 6.66(\mathrm{dd}, J=11.0 \mathrm{~Hz}, 17.6 \mathrm{~Hz}, 1 \mathrm{H}), 7.34(\mathrm{~m}, 4 \mathrm{H}) ;{ }^{13} \mathrm{C}-\mathrm{NMR}\left\{{ }^{1} \mathrm{H}\right\}\left(75 \mathrm{MHz} \mathrm{CDCl}_{3}\right) \delta$ 28.5, 80.8, 112.5, 118.6, 127.0, 132.7, 136.4, 138.1, 152.8; MS (E.I.) m/z (M) ${ }^{+}$calcd. 219.13 obsd. 219.10.

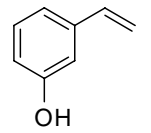

3-vinylphenol: ${ }^{7}$ To a $500 \mathrm{~mL}$ flame dried round bottom flask equipped with a stir bar, was added $8.75 \mathrm{~g}$ of methyltriphenylphosphonium bromide ( $24.5 \mathrm{mmol}, 2.25$ equiv.) and $100 \mathrm{~mL}$ of THF under a $\mathrm{N}_{2}$ atmosphere. To the cloudy white mixture, was added $2.81 \mathrm{~g}$ of $\mathrm{KO}^{t} \mathrm{Bu}$ $(25.0 \mathrm{mmol}, 2.50$ equiv. $)$ in three portions. The reaction mixture turned yellow and was stirred $4 \mathrm{~h}$. The mixture was cooled to $-78^{\circ} \mathrm{C}$ and $1.22 \mathrm{~g}$ of 3-hydroxybenzaldehyde (Acros) (10.0 mmol, 1.00 equiv.) dissolved in $10 \mathrm{~mL}$ of THF, was added dropwise via cannulation. The mixture was allowed to slowly warm to ambient temperature and stirred $12 \mathrm{~h}$. To the yellow mixture, was added $100 \mathrm{~mL}$ of saturated $\mathrm{NH}_{4} \mathrm{Cl}$ solution and the cloudy white solution was stirred for $1 \mathrm{~h}$. The mixture was transferred to a separatory funnel and was extracted three times with $30 \mathrm{~mL}$ of $\mathrm{Et}_{2} \mathrm{O}$. The organic extracts were combined, washed once with $100 \mathrm{~mL}$ of brine, dried over $\mathrm{MgSO}_{4}$, filtered, and the solvent removed in vacuo to yield a yellow oil. The product was purified by bulb to bulb distillation and isolated in $87 \%$ yield. The ${ }^{1} \mathrm{H}-\mathrm{NMR}$ spectrum was compared to the previously reported spectrum. ${ }^{8}$

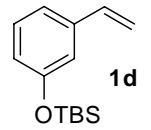

tert-butyldimethyl(3-vinylphenoxy)silane (1d): To a flame dried $25 \mathrm{~mL}$ round bottom flask equipped with a stir bar, was added $240 \mathrm{mg}$ of 3-vinylphenol (2.00 mmol, 1.00 equiv.) and $5.00 \mathrm{~mL}$ of $\mathrm{CH}_{2} \mathrm{Cl}_{2}$ under a $\mathrm{N}_{2}$ atmosphere. To the mixture was added $1.86 \mathrm{~mL}$ of TEA (4.00 mmol, 2.00 equiv.) and $1.00 \mathrm{~g}$ of tert-butylchlorodimethylsilane ( $4.00 \mathrm{mmol}, 2.0$ equiv.). The reaction mixture turned cloudy white and was stirred overnight. The mixture was filtered through Whatman filter paper and was rinsed with $\mathrm{CH}_{2} \mathrm{Cl}_{2}$. The mixture was washed with ca. $10 \mathrm{~mL} \mathrm{H}_{2} \mathrm{O}$, ca. $10 \mathrm{~mL}$ of sat. $\mathrm{NH}_{4} \mathrm{Cl}$, and was dried over $\mathrm{MgSO}_{4}$. The mixture was filtered and the solvent was removed in vacuo to produce a clear oil. The product was purified by silica gel flash chromatography eluting with pentane.

1d, Yield: $82 \%$ (386.1 mg); $\mathrm{R}_{\mathrm{f}}=0.88 \mathrm{w} / 20 \% \mathrm{Et}_{2} \mathrm{O} /$ Hexanes (silica); Clear oil; IR (neat) 3089, 2956, 2932 , 2859, 1599, 1578, 1484, 1279, 1157, 962, 840, $715 \mathrm{~cm}^{-1} ;{ }^{1} \mathrm{H}-\mathrm{NMR}$ (400 MHz, $\left.\mathrm{CDCl}_{3}\right): \delta 0.22(\mathrm{~s}, 6 \mathrm{H}), 1.0$ (s, 9H), 5.25 (dd, $J=0.7 \mathrm{~Hz}, 10.6 \mathrm{~Hz}, 1 \mathrm{H}), 5.72(\mathrm{dd}, J=0.7 \mathrm{~Hz}, 17.6 \mathrm{~Hz}, 1 \mathrm{H}), 6.67$ (dd, $J=10.6 \mathrm{~Hz}, 17.6$ $\mathrm{Hz}, 1 \mathrm{H}), 6.75$ (ddd, $J=0.7 \mathrm{~Hz}, 2.6 \mathrm{~Hz}, 8.1 \mathrm{~Hz}, 1 \mathrm{H}), 6.90$ (dd, $J=2.0 \mathrm{~Hz}, 2.0 \mathrm{~Hz}, 1 \mathrm{H}), 7.01-7.03(\mathrm{~m}, 1 \mathrm{H})$, 7.19 (dd, $J=8.0 \mathrm{~Hz}, 8.0 \mathrm{~Hz}, 1 \mathrm{H}) ;{ }^{13} \mathrm{C}-\mathrm{NMR}\left\{{ }^{1} \mathrm{H}\right\}\left(100 \mathrm{MHz}, \mathrm{CDCl}_{3}\right): \delta-4.2,18.8,25.9,114.1,118.0$, 119.7, 119.8, 129.6, 136.9, 139.3, 156.1; MS (ESI/APCI) m/z (MH) ${ }^{+}$calcd.: 235.1518 obsd.: 235.1512.

\section{Synthesis of Organostannane Reagents:}

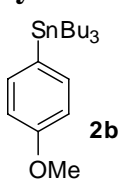

tributyl(4-methoxyphenyl)stannane (2b): ${ }^{9}$ To a flame dried $100 \mathrm{~mL}$ Schlenck flask equipped with a stirbar and a dried water condenser under a $\mathrm{N}_{2}$ atmosphere, was added $25.0 \mathrm{~mL}$ of THF and $585 \mathrm{mg}$ of magnesium turnings ( $24.0 \mathrm{mmol}, 1.60$ equiv.), which were activated by crushing with a mortar and pestle. To the stirred mixture, was added 4 drops of 1,2-dirbromoethane and $1.89 \mathrm{~mL}$ of 1-bromo-4-methoxybenzene (Aldrich) (15.0 mmol, 1.00 equiv.), which was added dropwise over 5 minutes. The mixture slowly turned dark brown and the stirred mixture was heated to reflux overnight. The reaction mixture was cooled to room temperature and was cannulated into a dried $100 \mathrm{~mL}$ Schlenk flask equipped with a stirbar and condenser under a $\mathrm{N}_{2}$ atmosphere. To the stirred mixture, was added $4.88 \mathrm{~mL}$ of $\mathrm{Bu}_{3} \mathrm{SnCl}$ (18.0 mmol, 1.20 equiv.) dropwise over 5 minutes. The stirred mixture was heated to reflux for $4 \mathrm{~h}$ and was cooled to room temperature. To the stirred mixture, was added ca. $20 \mathrm{~mL}$ of aqueous $1.00 \mathrm{M} \mathrm{NaOH}^{3}{ }^{3}$ After an hour the mixture was transferred to a separatory funnel and the aqueous layer was extracted three times with $20 \mathrm{~mL}$ of $\mathrm{Et}_{2} \mathrm{O}$. The organic extracts were collected and washed with $60 \mathrm{~mL}$ of brine, dried over $\mathrm{MgSO}_{4}$, filtered, and the solvent was removed in vacuo to yield a clear oil. The product was purified by silica gel flash chromatography eluting with $2 \% \mathrm{Et}_{2} \mathrm{O} /$ hexanes. The 
product was obtained as a clear oil in $87 \%$ yield and the ${ }^{1} \mathrm{H}-\mathrm{NMR}$ spectrum was compared to a previously reported spectrum. ${ }^{10}$

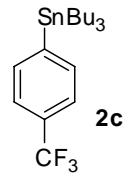

tributyl(4-(trifluoromethyl)phenyl)stannane (2c): The same procedure used for the synthesis of $\mathbf{2 b}$ was used except $2.38 \mathrm{~mL}$ of 1-bromo-4-(trifluoromethyl)benzene (Acros) $(15.0 \mathrm{mmol}$, 1.00 equiv.) was used and the product was purified by silica gel flash chromatography eluting with pentane. The product was obtained as a clear oil in $60 \%$ yield and the ${ }^{1} \mathrm{H}-\mathrm{NMR}$ spectrum was compared to a previously reported spectrum. ${ }^{11}$

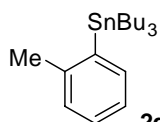

tributyl(o-tolyl)stannane (2d): The same procedure used for the synthesis of $\mathbf{2 b}$ was used except $1.78 \mathrm{~mL}$ of 2-bromotoluene (Aldrich) $(15.0 \mathrm{mmol}, 1.00$ equiv.) was used and the product was purified by silica gel flash chromatography eluting with hexanes.

2d, Yield: 97\% (5.56 g); $\mathrm{R}_{\mathrm{f}}=0.62 \mathrm{w} /$ Hexanes (silica); Clear oil; IR (neat) 3053, 2958, 2853, 1563, 1421, $1340,1073,869,741,688,594 \mathrm{~cm}^{-1},{ }^{1} \mathrm{H}-\mathrm{NMR}\left(300 \mathrm{MHz}, \mathrm{CDCl}_{3}\right): \delta 0.88(\mathrm{t}, J=7.3 \mathrm{~Hz}, 9 \mathrm{H}), 1.04-1.10(\mathrm{~m}$, $6 \mathrm{H}), 1.26-1.30(\mathrm{~m}, 6 \mathrm{H}), 1.47-1.57(\mathrm{~m}, 6 \mathrm{H}), 2.39(\mathrm{~s}, 3 \mathrm{H}), 7.10-7.25(\mathrm{bm}, 3 \mathrm{H}), 7.38(\mathrm{dd}, J=1.5 \mathrm{~Hz}, 7.0 \mathrm{~Hz}$, $1 \mathrm{H}) ;{ }^{13} \mathrm{C}-\mathrm{NMR}\left\{{ }^{1} \mathrm{H}\right\}\left(100 \mathrm{MHz}, \mathrm{CDCl}_{3}\right): \delta 10.3,13.9,25.2,27.7,29.4,125.1,128.5,129.1,136.8,142.1$, 144.8; $\mathrm{MS}(\mathrm{APCI}) \mathrm{m} / \mathrm{z}(\mathrm{MH})^{+}$calcd.: 383.2 obsd.: 383.8 . (the intensity of the $\left(\mathrm{MH}^{+}\right)$peak was very small)

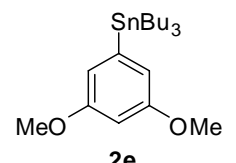

tributyl(3,5-dimethoxyphenyl)stannane (2e): The same procedure used for the synthesis of $\mathbf{2 b}$ was used except $2.59 \mathrm{~g}$ of 1-chloro-3,5-dimethoxybenzene (TCI America) $(15.0 \mathrm{mmol}, 1.00$ equiv.) was used and the product was purified by silica gel flash chromatography eluting with $5 \% \mathrm{Et}_{2} \mathrm{O} /$ hexanes.

2e, Yield: 65\% (4.18 g); $\mathrm{R}_{\mathrm{f}}=0.65 \mathrm{w} / 10 \% \mathrm{Et}_{2} \mathrm{O} /$ Hexanes (silica); Clear oil; IR (neat) 2956, 2926, 2851, $1560,1461,1378,1246,1156,1063,860,734,597 \mathrm{~cm}^{-1} ;{ }^{1} \mathrm{H}-\mathrm{NMR}\left(400 \mathrm{MHz}, \mathrm{CDCl}_{3}\right): \delta 0.90(\mathrm{t}, J=7.3 \mathrm{~Hz}$, 9H), 1.03-1.07 (m, 6H), 1.29-1.39 (m, 6H), 1.51-1.59 (m, 6H), 3.81 (s, 6H), 6.41 (dd, $J=2.3 \mathrm{~Hz}, 2.3 \mathrm{~Hz}$, 1H), $6.62(\mathrm{~d}, J=2.3 \mathrm{~Hz}, 2 \mathrm{H}) ;{ }^{13} \mathrm{C}-\mathrm{NMR}\left\{{ }^{1} \mathrm{H}\right\}\left(100 \mathrm{MHz}, \mathrm{CDCl}_{3}\right): \delta 9.8,13.8,27.6,29.3,55.1,99.9,114.0$, 144.1, 160.4; MS (ESI/APCI) m/z (MH) calcd.: 429.1816 obsd.: 429.1815.

$\mathrm{SnBu}_{3}$ tributyl(3,4-dihydro-2H-pyran-6-yl)stannane (2f): Stannane $2 \mathrm{f}$ was synthesized according<smiles>CC1=CCCCO1</smiles>
to a previously reported procedure and the ${ }^{1} \mathrm{H}-\mathrm{NMR}$ spectrum was compared to the previously reported spectrum. ${ }^{12}$

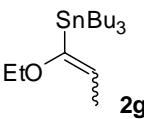

tributyl(1-ethoxyprop-1-enyl)stannane (2g): Stannane $2 \mathrm{~g}$ was synthesized according to a previously reported procedure and the ${ }^{1} \mathrm{H}-\mathrm{NMR}$ spectrum was compared to the previously reported spectrum. ${ }^{13}$

tributyl(2-methylprop-1-enyl)stannane (2h): Stannane 2g was synthesized according to a previously reported procedure ${ }^{14}$ from (2-methylprop-1-enyl)magnesium bromide (Aldrich) and the ${ }^{1} \mathrm{H}-\mathrm{NMR}$ spectrum was compared to the previously reported spectrum. ${ }^{15}$

General Reductive Coupling Procedure: IMPORTANT NOTE: A $100 \mathrm{~mL}$ thick-wall glass pressure vessel with an approximate $4.5 \mathrm{~cm}$ diameter was used. The use of smaller diameter vessels led to catalyst decomposition, which can be attributed to inefficient mass transport of $\mathrm{O}_{2}{ }^{16}$

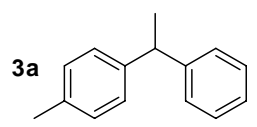

1-methyl-4-(1-phenylethyl)benzene (3a): A three-way joint was fitted to the side arm of an oven dried $100 \mathrm{~mL}$ thick-wall glass pressure vessel equipped with a stir bar. An $\mathrm{O}_{2}$ tank was connected to the three-way joint and $\mathrm{O}_{2}$ was flowed through the vessel. To the vessel, was added $65.2 \mathrm{mg}$ of $\mathrm{MnO}_{2}(0.750 \mathrm{mmol}, 0.750$ equiv. $), 4.30 \mathrm{~mL}$ of 2-propanol, $0.200 \mathrm{~mL}$ of a $2.00 \mathrm{M}$ solution of $(-)$-sparteine $(0.400 \mathrm{mmol}, 0.400$ equiv. $)$ in 2-propanol, 
$0.132 \mathrm{~mL}$ of 4 -methylstyrene (1a) $\left(1.00 \mathrm{mmol}\right.$, 1.00 equiv.), and $490 \mu \mathrm{L}$ of $\mathrm{PhSnBu}_{3}(1.50 \mathrm{mmol}$, 1.50 equiv.). The vessel was sealed, pressurized to $25 \mathrm{psi}$, evacuated via water aspiration, and repressurized to $25 \mathrm{psi}_{2}$. This procedure was repeated three times. The vessel was sealed and the mixture was stirred vigorously for ca. $20 \mathrm{~min}$ at room temperature at $25 \mathrm{psi}_{2}$. The vessel was opened and $\mathrm{O}_{2}$ was flowed through the vessel. To the stirred mixture, was added $10.3 \mathrm{mg}$ of $\operatorname{Pd}[(-)$-sparteine $] \mathrm{Cl}_{2}$ ( $0.0250 \mathrm{mmol}, 0.0250$ equiv.). The vessel was immediately pressurized to $25 \mathrm{psi}_{2}$ and was sealed. The three-way joint was removed and the reaction mixture was stirred vigorously for $5 \mathrm{~min}$ at room temperature. The mixture was then heated to $60^{\circ} \mathrm{C}$ in an oil bath and was stirred vigorously for $18 \mathrm{~h}$. The vessel was removed from the oil bath and cooled to room temperature. To the reaction mixture, was added $5.0 \mathrm{~mL}$ of a $1.00 \mathrm{M}$ solution of aqueous $\mathrm{NaOH}$ and was stirred for $1 \mathrm{~h}^{3}$ The mixture was filtered through Whatman filter paper, rinsed with ca. $10.0 \mathrm{~mL}$ of $\mathrm{Et}_{2} \mathrm{O}$, and was transferred to a separatory funnel. The aqueous layer was extracted three times with $20.0 \mathrm{~mL}$ of $\mathrm{Et}_{2} \mathrm{O}$, all of the organic extracts were combined, washed with $40.0 \mathrm{~mL}$ of brine, and dried over $\mathrm{MgSO}_{4}$. The mixture was filtered and the solvent was removed in vacuo. The product was purified via alumina gel flash chromatography by eluting with pentane. The ${ }^{1} \mathrm{H}-\mathrm{NMR}$ spectrum, see below, was compared to a previously reported spectrum. ${ }^{4}$ For each substrate, this procedure was performed twice and the average isolated yield is reported. 3a, Yield: $76 \%(144.6 \mathrm{mg}$ and $155.2 \mathrm{mg}$ ); $\mathrm{R}_{\mathrm{f}}=0.65 \mathrm{w} /$ Hexanes (alumina), PMA stain.

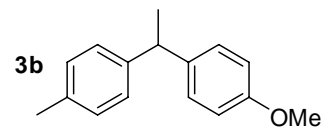

1-methoxy-4-(1-p-tolylethyl)benzene (3b): The same procedure used to synthesize 3a was used except $596 \mathrm{mg}$ of tributyl(4-methoxyphenyl)stannane (2b) ( $1.50 \mathrm{mmol}, 1.50$ equiv.) was added via syringe and the product was purified via alumina gel flash chromatography by eluting with pentane to $3 \% \mathrm{Et}_{2} \mathrm{O} /$ pentane.

The ${ }^{1} \mathrm{H}-\mathrm{NMR}$ spectrum, see below, was compared to a previously reported spectrum. ${ }^{17}$ 3b. Yield: $70 \%$ (159.3 $\mathrm{mg}$ and $158.2 \mathrm{mg}$ ); $\mathrm{R}_{\mathrm{f}}=0.23 \mathrm{w} /$ Hexanes (alumina), PMA stain.

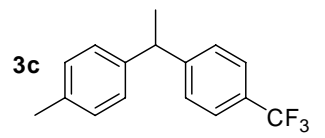

1-methyl-4-(1-(4-(trifluoromethyl)phenyl)ethyl)benzene (3c): The same procedure used to synthesize 3a was used except $653 \mathrm{mg}$ of tributyl(4(trifluoromethyl)phenyl)stannane (2c) $(1.50 \mathrm{mmol}, 1.50$ equiv.) was added via syringe and the product was purified via alumina gel flash chromatography by

eluting with pentane.

3c, Yield: $67 \%$ (179.6 mg and $174.4 \mathrm{mg}$ ); $\mathrm{R}_{\mathrm{f}}=0.61 \mathrm{w} /$ Hexanes (alumina), PMA stain. IR (neat) 3021, 2972, 2932, 2878, 1918, 1618, 1513, 1415, 1326, 1164, 1122, 1018, 819, 730, 628, $535 \mathrm{~cm}^{-1}$; ${ }^{1} \mathrm{H}-\mathrm{NMR}$ $\left(400 \mathrm{MHz}, \mathrm{CDCl}_{3}\right): \delta 1.65(\mathrm{~d}, J=7.3 \mathrm{~Hz}, 3 \mathrm{H}), 2.33(\mathrm{~s}, 3 \mathrm{H}), 4.18(\mathrm{q}, J=7.3 \mathrm{~Hz}, 1 \mathrm{H}), 7.09-7.14(\mathrm{~m}, 4 \mathrm{H})$, $7.33(\mathrm{~d}, J=8.4 \mathrm{~Hz}, 2 \mathrm{H}), 7.53(\mathrm{~d}, J=8.1 \mathrm{~Hz}, 2 \mathrm{H}) ;{ }^{13} \mathrm{C}-\mathrm{NMR}\left\{{ }^{1} \mathrm{H}\right\}\left(100 \mathrm{MHz}, \mathrm{CDCl}_{3}\right): \delta 21.2,21.9,44.6$, 125.6, 127.7, 128.2, 129.6, 136.3, 142.6, 151.0; MS (ESI/APCI) $\mathrm{m} / \mathrm{z}(\mathrm{M}-\mathrm{H})^{+}$calcd.: 263.1048 obsd.: 263.1041 .

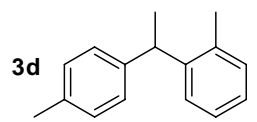

2,4'-(ethane-1,1-diyl)bis(methylbenzene) (3d): The same procedure used to synthesize 3a was used except $572 \mathrm{mg}$ of tributyl (o-tolyl)stannane (2d) $(1.50 \mathrm{mmol}$, 1.50 equiv.) was added via syringe, $14.4 \mathrm{mg}$ of $\mathrm{Pd}[(-)$-sparteine $] \mathrm{Cl}_{2}(0.0350 \mathrm{mmol}$, 0.0350 equiv.) was added, and the product was purified via alumina gel flash chromatography by eluting with pentane.

3d, Yield: $59 \%$ (119.5 mg and $126.6 \mathrm{mg}$ ); $\mathrm{R}_{\mathrm{f}}=0.57 \mathrm{w} / \mathrm{Hexanes}$ (alumina), PMA stain. IR (neat) 3047, 3020, 2967, 2927, 2872, 1901, 1512, 1488, 1375, 1330, 1048, 818, 767, 733, $552 \mathrm{~cm}^{-1} ;{ }^{1} \mathrm{H}-\mathrm{NMR}$ (400 MHz, $\left.\mathrm{CDCl}_{3}\right): \delta 1.60(\mathrm{~d}, J=7.0 \mathrm{~Hz}, 3 \mathrm{H}), 2.25(\mathrm{~s}, 3 \mathrm{H}), 2.31(\mathrm{~s}, 3 \mathrm{H}), 4.29(\mathrm{q}, J=7.3 \mathrm{~Hz}, 1 \mathrm{H}), 7.07(\mathrm{dd}, J=8.2 \mathrm{~Hz}$, $11.9 \mathrm{~Hz}, 4 \mathrm{H}), 7.13-7.14(\mathrm{~m}, 2 \mathrm{H}), 7.19-7.23(\mathrm{~m}, 1 \mathrm{H}), 7.27-7.29(\mathrm{~m}, 1 \mathrm{H}) ;{ }^{13} \mathrm{C}-\mathrm{NMR}\left\{{ }^{1} \mathrm{H}\right\}\left(100 \mathrm{MHz}, \mathrm{CDCl}_{3}\right)$ : $\delta$ 20.0, 21.2, 22.5, 40.8, 126.3, 126.8, 127.8, 129.3, 130.6, 135.5, 136.3, 143.5, 144.4; MS (ESI/APCI) m/z (M-H) ${ }^{+}$calcd.: 209.1330 obsd.: 209.1329.

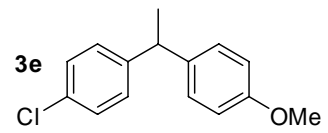

1-chloro-4-(1-(4-methoxyphenyl)ethyl)benzene (3e): The same procedure used to synthesize 3a was used except $0.120 \mathrm{~mL}$ of 4-chlorostyrene $(1.00 \mathrm{mmol}$, 1.00 equiv.), $596 \mathrm{mg}$ of tributyl(4-methoxyphenyl)stannane (2b) $(1.50 \mathrm{mmol}$, 1.50 equiv.) was added via syringe and the product was purified via alumina gel 
flash chromatography by eluting with pentane to $10 \% \mathrm{Et}_{2} \mathrm{O} /$ pentane. The ${ }^{1} \mathrm{H}-\mathrm{NMR}$ spectrum, see below, was compared to a previously reported spectrum. ${ }^{18} 3 \mathbf{e}$, Yield: $65 \%(157.4 \mathrm{mg}$ and $161.7 \mathrm{mg}) ; \mathrm{R}_{\mathrm{f}}=0.23 \mathrm{w} /$ Hexanes (alumina), PMA stain.

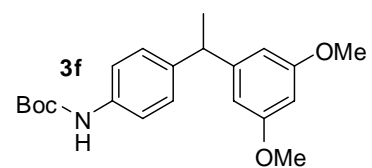

added $32.6 \mathrm{mg}$ of $\mathrm{MnO}_{2}$

tert-butyl-4-(1-(3,5-dimethoxyphenyl)ethyl)phenylcarbamate (3f): A threeway joint was fitted to the side arm of an oven dried $100 \mathrm{~mL}$ thick-wall glass pressure vessel equipped with a stir bar. An $\mathrm{O}_{2}$ tank was connected to the three-way joint and $\mathrm{O}_{2}$ was flowed through the vessel. To the vessel, was solution of (-)-sparteine $(0.200 \mathrm{mmol}, \quad 0.400$ equiv. $)$ in 2-propanol, $110 \mathrm{mg}$ of tert-butyl 4vinylphenylcarbamate (1c) $\quad(0.500 \mathrm{mmol}, \quad 1.00$ equiv. $), \quad$ and $\quad 320 \mathrm{~mL}$ of tributyl(3,5dimethoxyphenyl)stannane (2e) $(0.750 \mathrm{mmol}, 1.50$ equiv.). The vessel was sealed, pressurized to $25 \mathrm{psi}$, evacuated via water aspiration, and re-pressurized to $25 \mathrm{psi}_{2}$. This procedure was repeated three times. The vessel was sealed and the mixture was stirred vigorously for ca. $20 \mathrm{~min}$ at room temperature at 25 psi $\mathrm{O}_{2}$. The vessel was opened and $\mathrm{O}_{2}$ was flowed through the vessel. To the stirred mixture, was added $5.20 \mathrm{mg}$ of $\mathrm{Pd}[(-)$-sparteine $] \mathrm{Cl}_{2}(0.0125 \mathrm{mmol}, 0.0250$ equiv. $)$. The vessel was immediately pressurized to 25 psi $\mathrm{O}_{2}$ and was sealed. The three-way joint was removed and the reaction mixture was stirred vigorously for $5 \mathrm{~min}$ at room temperature. The mixture was then heated to $60^{\circ} \mathrm{C}$ in an oil bath and was stirred vigorously for $18 \mathrm{~h}$. The vessel was removed from the oil bath and cooled to room temperature. To the reaction mixture, was added $2.5 \mathrm{~mL}$ of a $1.00 \mathrm{M}$ solution of aqueous $\mathrm{NaOH}$ and was stirred for $1 \mathrm{~h}^{3}$ The mixture was filtered through Whatman filter paper, rinsed with ca. $5.0 \mathrm{~mL}$ of $\mathrm{Et}_{2} \mathrm{O}$, and was transferred to a separatory funnel. The aqueous layer was extracted three times with $10.0 \mathrm{~mL}$ of $\mathrm{Et}_{2} \mathrm{O}$, all of the organic extracts were combined, washed with $20.0 \mathrm{~mL}$ of brine, and dried over $\mathrm{MgSO}_{4}$. The mixture was filtered and the solvent was removed in vacuo. The product was purified via silica gel flash chromatography by eluting with $2 \%$ EtOAc/hexanes to $10 \%$ EtOAc/hexanes.

3f, Yield: 58\% (104.4 mg and $98.3 \mathrm{mg}) ; \mathrm{R}_{\mathrm{f}}=0.55 \mathrm{w} / 30 \%$ EtOAc/hexanes (silica), PMA stain. IR (neat) 3340, 2970, 2935, 2837, 2284, 1899, 1725, 1598, 1524, 1460, 1427, 1411, 1314, 1158, 1051, 1019, 836, $696 \mathrm{~cm}^{-1} ;{ }^{1} \mathrm{H}-\mathrm{NMR}\left(400 \mathrm{MHz}, \mathrm{CDCl}_{3}\right): \delta 1.50(\mathrm{~s}, 9 \mathrm{H}), 1.57(\mathrm{~d}, J=7.3 \mathrm{~Hz}, 3 \mathrm{H}), 3.74(\mathrm{~s}, 6 \mathrm{H}), 4.02(\mathrm{q}, J$ $=7.2 \mathrm{~Hz}, 1 \mathrm{H}), 6.28(\mathrm{dd}, J=2.4 \mathrm{~Hz}, 2.4 \mathrm{~Hz}, 1 \mathrm{H}), 6.36(\mathrm{~d}, J=2.2 \mathrm{~Hz}, 2 \mathrm{H}), 6.39-6.41$ (bs, 1H), 7.12-7.15 (m, 2H), 7.24-7.29 (m, 2H); ${ }^{13} \mathrm{C}-\mathrm{NMR}\left\{{ }^{1} \mathrm{H}\right\}\left(75 \mathrm{MHz}, \mathrm{CDCl}_{3}\right): \delta$ 22.0, 28.6, 44.6, 55.4, 80.6, 97.9, 106.2, 118.9 , 128.2, 136.6, 141.0, 149.2, 153.2, 160.9; MS (ESI/APCI) m/z (MNa) ${ }^{+}$calcd.: 380.1838 obsd. 380.1840.

$3 g$<smiles>COc1cccc(C(C)c2cc(OC)cc(OC)c2)c1</smiles>

tert-butyl(3-(1-(3,5-dimethoxyphenyl)ethyl)phenoxy)dimethylsilane (3g): The same procedure used to synthesize $3 f$ was used except $117 \mathrm{mg}$ of tertbutyldimethyl(3-vinylphenoxy)silane (1d) (0.500 mmol, 1.00 equiv.) was added via syringe, $7.20 \mathrm{mg}$ of $\mathrm{Pd}[(-)$-sparteine $] \mathrm{Cl}_{2}$ (0.0350 mmol, 0.0350 equiv.) was added, in the workup $2 \mathrm{~mL}$ of aqueous $0.5 \mathrm{M} \mathrm{NaOH}$ was used (stirred for 20 minutes instead of $1 \mathrm{~h}$ ), and the product was purified via alumina gel flash chromatography by eluting with $1 \% \mathrm{Et}_{2} \mathrm{O} /$ pentane to $12 \%$ $\mathrm{Et}_{2} \mathrm{O} /$ pentane.

3g, Yield: 55\% (105.1 mg and $99.8 \mathrm{mg}$ ); $\mathrm{R}_{\mathrm{f}}=0.43 \mathrm{w} / 5 \% \mathrm{Et}_{2} \mathrm{O} /$ hexanes (alumina), PMA stain. IR (neat) 2957, 2858, 1740, 1598, 1464, 1278, 1202, 1155, 1048, 957, 836, 784, $698 \mathrm{~cm}^{-1}$; ${ }^{1} \mathrm{H}-\mathrm{NMR}(300 \mathrm{MHz}$, $\left.\mathrm{CDCl}_{3}\right): \delta 0.16(\mathrm{~s}, 6 \mathrm{H}), 0.96(\mathrm{~s}, 9 \mathrm{H}), 1.58(\mathrm{~d}, J=7.1 \mathrm{~Hz}, 3 \mathrm{H}), 3.76(\mathrm{~s}, 6 \mathrm{H}), 4.01(\mathrm{q}, J=7.3 \mathrm{~Hz}, 1 \mathrm{H}), 6.29$ $(\mathrm{dd}, J=2.3 \mathrm{~Hz}, 2.3 \mathrm{~Hz}, 1 \mathrm{H}), 6.37(\mathrm{~d}, J=2.2 \mathrm{~Hz}, 2 \mathrm{H}), 6.66$ (ddd, $J=1.1 \mathrm{~Hz}, 2.5 \mathrm{~Hz}, 8.0 \mathrm{~Hz}, 1 \mathrm{H}), 6.70,(\mathrm{dd}$, $J=2.1 \mathrm{~Hz}, 2.1 \mathrm{~Hz}, 1 \mathrm{H}), 6.79-6.82(\mathrm{~m}, 1 \mathrm{H}), 7.12(\mathrm{dd}, J=7.8 \mathrm{~Hz}, 7.8 \mathrm{~Hz}, 1 \mathrm{H}) ;{ }^{13} \mathrm{C}-\mathrm{NMR}\left\{{ }^{1} \mathrm{H}\right\}(100 \mathrm{MHz}$, $\left.\mathrm{CDCl}_{3}\right): \delta-4.2,18.4,21.8,25.9,45.0,55.4,98.0,106.1,117.9,119.6,120.8,129.3,147.8,149.0,155.8$, 160.9; MS (ESI/APCI) m/z (MH) ${ }^{+}$calcd.: 373.2199 obsd. 373.2205.

$3 h$

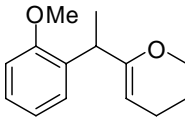

6-(1-(2-methoxyphenyl)ethyl)-3,4-dihydro-2H-pyran (3h): The same procedure used to synthesize 3a was used except $0.134 \mu \mathrm{L}$ of 2-vinylanisole (1e) $(1.00 \mathrm{mmol}$, 1.00 equiv.) was added via syringe, $560 \mathrm{mg}$ of tributyl(3,4-dihydro-2H-pyran-6yl)stannane (2f) (1.50 mmol, 1.50 equiv.) was added via syringe, $14.4 \mathrm{mg}$ of $\operatorname{Pd}[(-)-$ sparteine $] \mathrm{Cl}_{2}(0.0350 \mathrm{mmol}, 0.0350$ equiv. $)$ was added, and the product was purified via alumina gel flash chromatography by eluting with pentane to $2 \% \mathrm{Et}_{2} \mathrm{O} /$ pentane . 
3h, Yield: $63 \%$ (141.0 mg and $135.2 \mathrm{mg}$ ); $\mathrm{R}_{\mathrm{f}}=0.58 \mathrm{w} / 10 \% \mathrm{Et}_{2} \mathrm{O} /$ pentane (silica), PMA stain. Clear oil; IR (neat) 3490, 3067, 2935, 2842, 1723, 1669, 1598, 1491, 1461, 1241, 1072, 915, $754 \mathrm{~cm}^{-1}$; ${ }^{1} \mathrm{H}-\mathrm{NMR}$ (300 $\left.\mathrm{MHz}, \mathrm{CDCl}_{3}\right): \delta 1.26(\mathrm{~d}, J=7.1 \mathrm{~Hz}, 3 \mathrm{H}), 1.79$ (quint, $\left.J=5.7 \mathrm{~Hz}, 2 \mathrm{H}\right), 2.01-2.10(\mathrm{~m}, 2 \mathrm{H}), 3.83(\mathrm{~s}, 3 \mathrm{H})$, 3.86-4.02 (m, 3H), 4.63 (t, J = 3.7 Hz, 1H), 6.82-6.94 (m, 2H), 7.14-7.20 (m, 1H), 7.25-7.29 (m, $1 \mathrm{H}) ;{ }^{13} \mathrm{C}-$ NMR $\{1 \mathrm{H}\}\left(75 \mathrm{MHz}, \mathrm{CDCl}_{3}\right): \delta 18.8,20.6,22.7,36.2,55.7,66.5,95.8,110.7,120.7,127.2,127.4,133.4$, 157.0, 157.2; MS (ESI/APCI) m/z (MH) calcd.: 219.1385 obsd.: 219.1390.

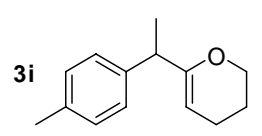

6-(1-p-tolylethyl)-3,4-dihydro-2H-pyran (3i): The same procedure used to synthesize 3a was used except $560 \mathrm{mg}$ of tributyl(3,4-dihydro-2H-pyran-6-yl)stannane (2f) $\left(1.50 \mathrm{mmol}, 1.50\right.$ equiv.) was added via syringe, $14.4 \mathrm{mg}$ of $\operatorname{Pd}[(-)$-sparteine $] \mathrm{Cl}_{2}$ ( $0.0350 \mathrm{mmol}, 0.0350$ equiv.) was added, and the product was purified via alumina gel flash chromatography by eluting with pentane to $2 \% \mathrm{Et}_{2} \mathrm{O} /$ pentane.

3i, Yield: $69 \%$ (144.2 $\mathrm{mg}$ and $134.5 \mathrm{mg}$ ); $\mathrm{R}_{\mathrm{f}}=0.28 \mathrm{w} /$ Pentane (alumina), PMA stain. Clear oil; IR (neat) 2968, 2929, 2871, 1896, 1659, 1513, 1372, 1231, 1158, 1071, 915, 862, $549 \mathrm{~cm}^{-1}$; ${ }^{1} \mathrm{H}-\mathrm{NMR}$ (300 MHz, $\left.\mathrm{CDCl}_{3}\right) \delta 1.34(\mathrm{~d}, J=7.1 \mathrm{~Hz}, 3 \mathrm{H}), 1.73-1.82(\mathrm{~m}, 2 \mathrm{H}), 2.00-2.06(\mathrm{~m}, 2 \mathrm{H}), 2.32(\mathrm{~s}, 3 \mathrm{H}), 3.35(\mathrm{q}, J=7.1 \mathrm{~Hz}$, $1 \mathrm{H}), 3.90-3.95(\mathrm{~m}, 2 \mathrm{H}), 4.60(\mathrm{t}, J=4.0 \mathrm{~Hz}, 1 \mathrm{H}), 7.08-7.20(\mathrm{~m}, 4 \mathrm{H}) ;{ }^{13} \mathrm{C}-\mathrm{NMR}\{1 \mathrm{H}\}\left(75 \mathrm{MHz}, \mathrm{CDCl}_{3}\right): \delta$ 19.5, 20.3, 21.0, 22.5, 43.6, 66.4, 95.3, 127.3, 129.2, 135.5, 141.7, 157.6; MS (ESI/APCI) m/z (MH) ${ }^{+}$calcd.: 203.1436 obsd.: 203.1434 .

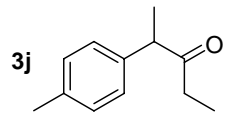

2-p-tolylpentan-3-one (3j): A three-way joint was fitted to the side arm of an oven dried $100 \mathrm{~mL}$ thick-wall glass pressure vessel equipped with a stir bar. An $\mathrm{O}_{2}$ tank was connected to the three-way joint and $\mathrm{O}_{2}$ was flowed through the vessel. To the vessel, was added $65.2 \mathrm{mg}$ of $\mathrm{MnO}_{2}(0.750 \mathrm{mmol}, 0.750$ equiv.), $4.30 \mathrm{~mL}$ of 2-propanol, $0.200 \mathrm{~mL}$ of a $2.00 \mathrm{M}$ solution of (-)-sparteine $(0.400 \mathrm{mmol}, 0.400$ equiv.) in 2-propanol, $0.132 \mathrm{~mL}$ of 4-methylstyrene (1a) $(1.00 \mathrm{mmol}, \quad 1.00$ equiv.), and $536 \mathrm{mg}$ of tributyl(1-ethoxyprop-1-enyl)stannane ( $2 \mathrm{~g}) \quad(1.50 \mathrm{mmol}$, 1.50 equiv.). The vessel was sealed, pressurized to $25 \mathrm{psi}$, evacuated via water aspiration, and repressurized to $25 \mathrm{psi}_{2}$. This procedure was repeated three times. The vessel was sealed and the mixture was stirred vigorously for ca. $20 \mathrm{~min}$ at room temperature at $25 \mathrm{psi} \mathrm{O}_{2}$. The vessel was opened and $\mathrm{O}_{2}$ was flowed through the vessel. To the stirred mixture, was added $14.4 \mathrm{mg}$ of $\operatorname{Pd}[(-)$-sparteine $] \mathrm{Cl}_{2}$ $\left(0.0350 \mathrm{mmol}, 0.0350\right.$ equiv.). The vessel was immediately pressurized to $25 \mathrm{psi} \mathrm{O}_{2}$ and was sealed. The three-way joint was removed and the reaction mixture was stirred vigorously for $5 \mathrm{~min}$ at room temperature. The mixture was then heated to $60^{\circ} \mathrm{C}$ in an oil bath and was stirred vigorously for $18 \mathrm{~h}$. The vessel was removed from the oil bath and cooled to room temperature. To the reaction mixture, was added $4.00 \mathrm{~mL}$ of a 1:1 solution of glacial acetic acid: $\mathrm{H}_{2} \mathrm{O}$ (ca. 35 mmol HOAc) and was stirred for $1 \mathrm{~h}$ until the enol ether had been completely hydrolyzed. ${ }^{19}$ To the reaction mixture, was added portion wise $10.0 \mathrm{~mL}$ of a $4.00 \mathrm{M}$ solution of aqueous $\mathrm{NaOH}$ (ca. $40 \mathrm{mmol}$ ) and was stirred for $1 \mathrm{~h}^{3}$ The mixture was filtered through Whatman filter paper, rinsed with ca. $10.0 \mathrm{~mL}$ of $\mathrm{Et}_{2} \mathrm{O}$, and was transferred to a separatory funnel. The aqueous layer was extracted three times with $20.0 \mathrm{~mL}$ of $\mathrm{Et}_{2} \mathrm{O}$ and all organic extracts were combined, washed with $40.0 \mathrm{~mL}$ of brine, and dried over $\mathrm{MgSO}_{4}$. The mixture was filtered and the solvent was removed in vacuo. The product was purified via alumina gel flash chromatography by eluting with pentane to $30 \% \mathrm{Et}_{2} \mathrm{O}$ /pentane. The ${ }^{1} \mathrm{H}-\mathrm{NMR}$ spectrum, see below, was compared to a previously reported spectrum. ${ }^{20}$ 3j, Yield: 52\% (92.4 mg and $91.6 \mathrm{mg}$ ); $\mathrm{R}_{\mathrm{f}}=0.51 \mathrm{w} / 5 \% \mathrm{Et}_{2} \mathrm{O} /$ hexanes (alumina), PMA stain.

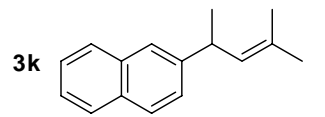

2-(4-methylpent-3-en-2-yl)naphthalene (3k): The same procedure used to synthesize 3a was used except $0.154 \mathrm{mg}$ of $95 \%$ 2-vinylnaphthalene $(1.00 \mathrm{mmol}$, 1.00 equiv.), $518 \mathrm{mg}$ of tributyl(2-methylprop-1-enyl)stannane (2h) $(1.50 \mathrm{mmol}$, 1.50 equiv. $)$ was added via syringe, $14.4 \mathrm{mg}$ of $\mathrm{Pd}[(-)$-sparteine $] \mathrm{Cl}_{2}(0.0350 \mathrm{mmol}, 0.0350$ equiv. $)$ was added, and the product was purified via alumina gel flash chromatography by eluting with pentane. The ${ }^{1} \mathrm{H}-\mathrm{NMR}$ spectrum, see below, was compared to a previously reported spectrum. ${ }^{21} 3 \mathbf{k}$, Yield: $50 \%$ (based on $95 \%$ purity of 2-vinylnaphthalene) $(97.0 \mathrm{mg}$ and $101.0 \mathrm{mg}) ; \mathrm{R}_{\mathrm{f}}=0.53 \mathrm{w} /$ Pentane (silica), PMA stain. 
Procedure for the Reductive Coupling Deuterium Labeling Experiment Performed in $\left(\mathrm{CH}_{3}\right)_{2} \mathrm{CHOD}$ : A three-way joint was fitted to the side arm of an oven dried $20 \mathrm{~mL}$ thick-wall glass pressure vessel equipped with a stir bar. An $\mathrm{O}_{2}$ tank was connected to the three-way joint and $\mathrm{O}_{2}$ was flowed through the vessel. To the vessel, was added $13.0 \mathrm{mg}$ of $\mathrm{MnO}_{2}(0.150 \mathrm{mmol}, 0.750$ equiv. $), 1.00 \mathrm{~mL}$ of $\left(\mathrm{CH}_{3}\right)_{2} \mathrm{CHOD}$ (98\% D incorporation, Acros Organics), $18.0 \mu \mathrm{L}$ of (-)-sparteine ( $0.0800 \mathrm{mmol}, 0.400$ equiv.), $26.0 \mu \mathrm{L}$ of 4-methylstyrene (1a) $\left(0.200 \mathrm{mmol}, 1.00\right.$ equiv.), and $98.0 \mu \mathrm{L}$ of $\mathrm{PhSnBu}_{3}$ (2a) (0.300 mmol, 1.50 equiv.). The vessel was sealed, pressurized to $25 \mathrm{psi}$, evacuated via water aspiration, and re-pressurized to $25 \mathrm{psi}_{2}$. This procedure was repeated three times. The vessel was sealed and the mixture was stirred vigorously for ca. $20 \mathrm{~min}$ at room temperature at $25 \mathrm{psi} \mathrm{O}_{2}$. The vessel was opened and $\mathrm{O}_{2}$ was flowed through the vessel. To the stirred mixture, was added $2.10 \mathrm{mg}$ of $\mathrm{Pd}[(-)$-sparteine $] \mathrm{Cl}_{2}(0.00500 \mathrm{mmol}, 0.0250$ equiv.). The vessel was immediately pressurized to $25 \mathrm{psi}_{2}$ and was sealed. The three-way joint was removed and the reaction mixture was stirred vigorously for $5 \mathrm{~min}$ at room temperature. The mixture was then heated to $60{ }^{\circ} \mathrm{C}$ in an oil bath and was stirred vigorously for $20 \mathrm{~h}$. The vessel was removed from the oil bath and cooled to room temperature. A $50 \mu \mathrm{L}$ aliquot of the reaction mixture was removed and passed through a small plug of silica with EtOAc as the elutant. The solution was analyzed by GC/MS (see data and calculations below).

Procedure for the Reductive Coupling Deuterium Labeling Experiment Performed in $\left(\mathrm{CH}_{3}\right)_{2} \mathrm{CDOH}$ : A three-way joint was fitted to the side arm of an oven dried $20 \mathrm{~mL}$ thick-wall glass pressure vessel equipped with a stir bar. An $\mathrm{O}_{2}$ tank was connected to the three-way joint and $\mathrm{O}_{2}$ was flowed through the vessel. To the vessel, was added $19.6 \mathrm{mg}$ of $\mathrm{MnO}_{2}(0.225 \mathrm{mmol}, 0.750$ equiv. $), 1.50 \mathrm{~mL}$ of $\left(\mathrm{CH}_{3}\right)_{2} \mathrm{CDOH}$ (99.5\% D incorporation, Cambridge Isotopes), $28.0 \mu \mathrm{L}$ of (-)-sparteine $(0.120 \mathrm{mmol}, 0.400$ equiv.), $40.0 \mu \mathrm{L}$ of 4 -methylstyrene (1a) $\left(0.300 \mathrm{mmol}, 1.00\right.$ equiv.), and $148 \mu \mathrm{L}$ of $\mathrm{PhSnBu}_{3}$ (2a) $(0.450 \mathrm{mmol}$, 1.50 equiv.). The vessel was sealed, pressurized to $25 \mathrm{psi}$, evacuated via water aspiration, and repressurized to $25 \mathrm{psi}_{2}$. This procedure was repeated three times. The vessel was sealed and the mixture was stirred vigorously for ca. $20 \mathrm{~min}$ at room temperature at $25 \mathrm{psi}_{2}$. The vessel was opened and $\mathrm{O}_{2}$ was flowed through the vessel. To the stirred mixture, was added $3.10 \mathrm{mg}$ of $\operatorname{Pd}[(-)$-sparteine $] \mathrm{Cl}_{2}$ $\left(0.00750 \mathrm{mmol}, 0.0250\right.$ equiv.). The vessel was immediately pressurized to $25 \mathrm{psi} \mathrm{O}_{2}$ and was sealed. The three-way joint was removed and the reaction mixture was stirred vigorously for $5 \mathrm{~min}$ at room temperature. The mixture was then heated to $60^{\circ} \mathrm{C}$ in an oil bath and was stirred vigorously for $20 \mathrm{~h}$. The vessel was removed from the oil bath and cooled to room temperature. A $50 \mu \mathrm{L}$ aliquot of the reaction mixture was removed and passed through a small plug of silica with EtOAc as the elutant. The solution was analyzed by GC/MS (see data and calculations below). To the remaining reaction mixture, was added $3.0 \mathrm{~mL}$ of a $1.00 \mathrm{M}$ solution of aqueous $\mathrm{NaOH}$ and was stirred for $1 \mathrm{~h}$. The mixture was filtered through Whatman filter paper, rinsed with ca. $5.0 \mathrm{~mL}$ of $\mathrm{Et}_{2} \mathrm{O}$, and was transferred to a separatory funnel. The aqueous layer was extracted three times with $20.0 \mathrm{~mL}$ of $\mathrm{Et}_{2} \mathrm{O}$ and all organic extracts were combined, washed with $30.0 \mathrm{~mL}$ of brine, and dried over $\mathrm{MgSO}_{4}$. The mixture was filtered and the solvent was removed in vacuo. The products were purified via alumina gel flash chromatography by eluting with pentane. The ${ }^{1} \mathrm{H}-\mathrm{NMR}$ spectra in $\mathrm{CD}_{2} \mathrm{Cl}_{2}$ was compared to the spectra of 3a prepared in unlabeled 2propanol (see spectra and calculations below). 


\section{GC/MS Data for the Reductive Coupling Product 3a:}

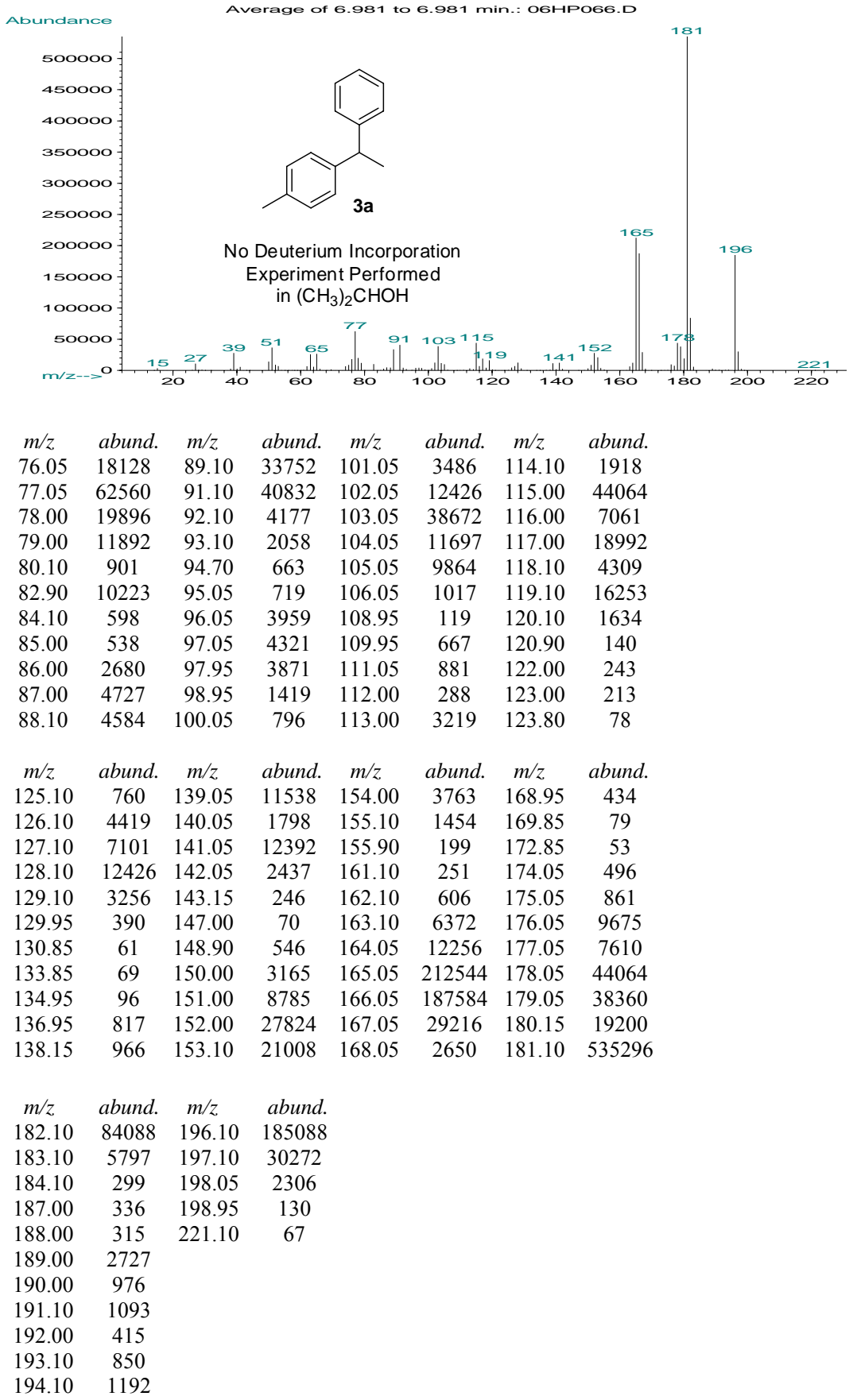


GC/MS Data for the Reductive Coupling Experiment Performed in $\left(\mathrm{CH}_{3}\right)_{2} \mathrm{CHOD:}$

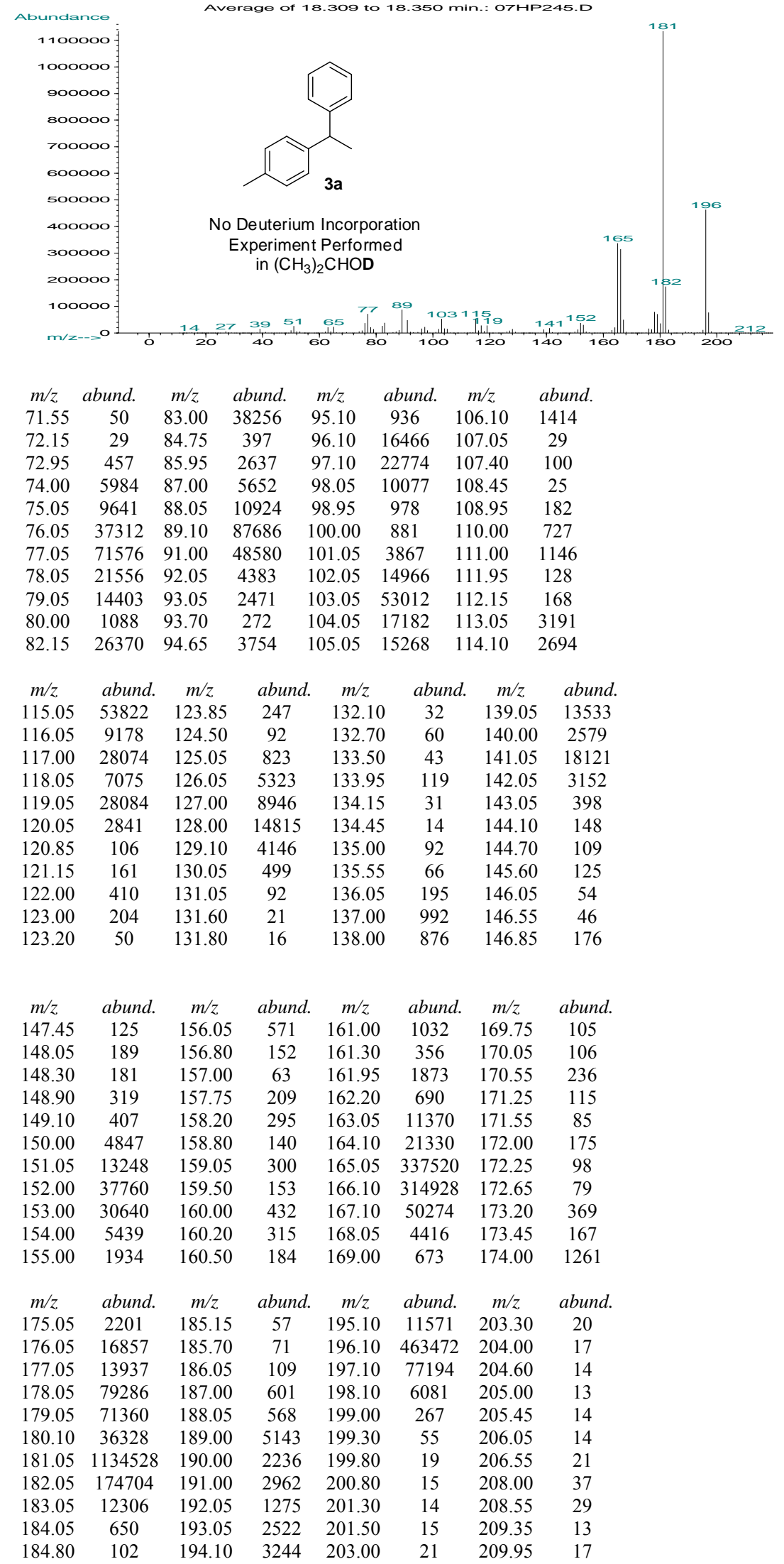


Calculation of the Deuterium Incorporation for Experiment Performed in $\left(\mathrm{CH}_{3}\right)_{2} \mathrm{CHOD}:^{22}$<smiles>Cc1ccc(C(C)c2ccccc2)cc1</smiles>

\begin{tabular}{|c|c|c|c|c|c|c|}
\hline \# of Deuterium Atoms & 0 & 1 & 2 & 3 & 4 & \multirow{5}{*}{$\begin{array}{c}(\mathrm{M}+1) / \mathrm{M} \text { not labeled: } \\
0.16\end{array}$} \\
\hline & $\mathbf{M}$ & $M+1$ & $M+2$ & $M+3$ & $M+4$ & \\
\hline Molecular Ions & 196 & 197 & 198 & 199 & 200 & \\
\hline Abund. Unlabeled & 185088 & 30272 & 2306 & 130 & & \\
\hline Abund. Labeled & 463472 & 77194 & 6081 & 267 & 15 & \\
\hline Relative Abund. Unlabeled & 100 & 16.36 & 1.25 & 0.07 & & \multirow[b]{3}{*}{$\left(9.76^{\star} 0.16\right)=1.60$} \\
\hline Relative Abund. Labeled & 100.00 & 16.66 & 1.31 & 0.06 & & \\
\hline $\begin{array}{l}\text { unlabeled: } \\
\text { difference: }\end{array}$ & 100.00 & $\begin{array}{l}16.36 \\
0.30\end{array}$ & & & & \\
\hline $\begin{array}{l}\text { D-1 } \\
\text { difference }\end{array}$ & & 0.30 & $\begin{array}{l}0.05 \\
1.26\end{array}$ & & & \multirow[t]{2}{*}{$(98.40 * 0.16)=16.09$} \\
\hline $\begin{array}{l}\text { D-2 } \\
\text { difference }\end{array}$ & & & 1.26 & $\begin{array}{l}0.21 \\
0.00\end{array}$ & & \\
\hline D-3 & & & & 0.00 & & \multirow{2}{*}{ sum relative abund. 110.6} \\
\hline Percent Distribution & 98.5 & 0.3 & 1.2 & 0.0 & & \\
\hline
\end{tabular}

\section{GC/MS Data for the Reductive Coupling Experiment Performed in $\left(\mathrm{CH}_{3}\right)_{2} \mathrm{CDOH}$ :}

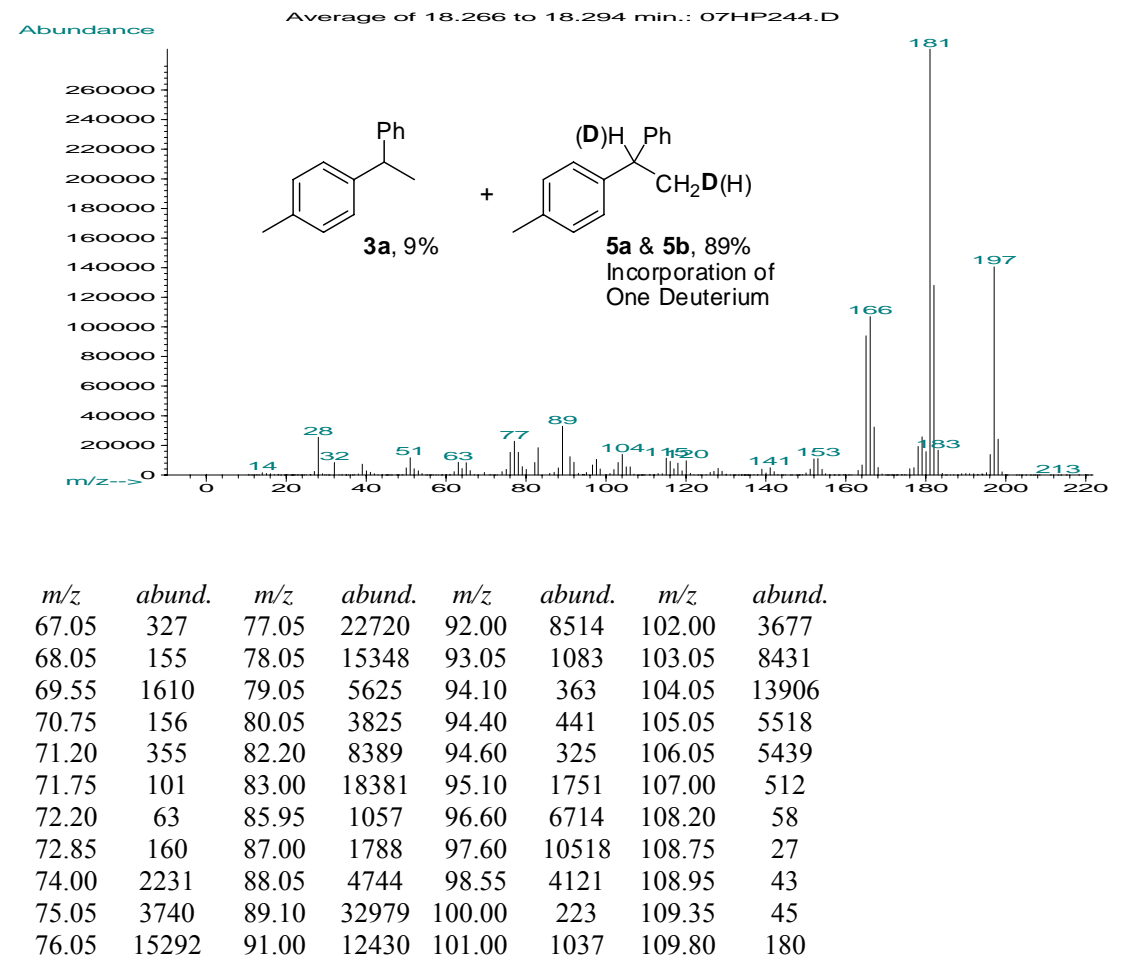




\begin{tabular}{|c|c|c|c|c|c|c|c|}
\hline$m / z$ & abund. & $m / z$ & abund. & $m / z$ & abund. & $m / z$ & abund. \\
\hline 110.85 & 312 & 120.05 & 9503 & 129.90 & 155 & 135.35 & 45 \\
\hline 111.05 & 110 & 121.10 & 1178 & 130.10 & 516 & 135.55 & 27 \\
\hline 111.85 & 50 & 122.00 & 157 & 131.10 & 144 & 136.15 & 105 \\
\hline 112.15 & 187 & 123.00 & 63 & 131.95 & 60 & 137.00 & 224 \\
\hline 113.05 & 897 & 123.60 & 71 & 132.30 & 19 & 137.85 & 95 \\
\hline 114.05 & 857 & 124.05 & 65 & 133.10 & 30 & 138.00 & 335 \\
\hline 115.05 & 11439 & 125.00 & 273 & 133.80 & 54 & 139.00 & 3902 \\
\hline 116.05 & 9213 & 126.05 & 1683 & 134.00 & 83 & 140.05 & 1434 \\
\hline 117.00 & 4178 & 127.00 & 2525 & 134.45 & 37 & 141.05 & 4906 \\
\hline 118.00 & 7960 & 128.05 & 4497 & 134.65 & 45 & 142.05 & 2273 \\
\hline 119.05 & 2739 & 129.05 & 2465 & 134.95 & 51 & 143.00 & 453 \\
\hline$m / z$ & abund. & $\mathrm{m} / \mathrm{z}$ & abund. & $\mathrm{m} / \mathrm{z}$ & abund. & $\mathrm{m} / \mathrm{z}$ & abund. \\
\hline 143.95 & 81 & 152.00 & 10809 & 160.60 & 165 & 170.25 & 44 \\
\hline 144.25 & 36 & 153.00 & 11143 & 161.00 & 193 & 170.55 & 40 \\
\hline 144.95 & 114 & 154.05 & 3761 & 161.50 & 162 & 171.05 & 75 \\
\hline 146.15 & 61 & 154.95 & 809 & 163.05 & 3131 & 171.35 & 34 \\
\hline 146.65 & 73 & 156.05 & 429 & 164.05 & 6813 & 171.75 & 118 \\
\hline 147.65 & 52 & 157.00 & 42 & 165.05 & 93936 & 171.95 & 57 \\
\hline 148.25 & 29 & 157.30 & 108 & 166.10 & 106925 & 172.55 & 47 \\
\hline 148.50 & 151 & 158.10 & 60 & 167.10 & 32413 & 172.85 & 119 \\
\hline 149.15 & 238 & 158.55 & 165 & 168.05 & 5016 & 173.05 & 86 \\
\hline 150.05 & 1432 & 159.40 & 188 & 169.05 & 691 & 173.90 & 333 \\
\hline 151.05 & 3890 & 159.60 & 79 & 170.00 & 110 & 174.15 & 163 \\
\hline$m / z$ & abund. & $m / z$ & abund. & $m / z$ & abund. & $m / z$ & abund. \\
\hline 174.65 & 232 & 184.90 & 109 & 194.05 & 784 & 204.00 & 59 \\
\hline 175.05 & 319 & 185.15 & 23 & 194.30 & 266 & 205.00 & 21 \\
\hline 176.00 & 4257 & 186.15 & 148 & 195.15 & 1484 & 206.15 & 18 \\
\hline 177.05 & 4884 & 187.00 & 203 & 196.10 & 13718 & 206.85 & 24 \\
\hline 178.05 & 19304 & 188.00 & 231 & 197.10 & 140512 & 207.35 & 42 \\
\hline 179.05 & 25685 & 188.95 & 873 & 198.10 & 24168 & 208.35 & 24 \\
\hline 180.05 & 15682 & 190.00 & 994 & 199.05 & 2093 & 211.15 & 48 \\
\hline 181.05 & 287573 & 190.95 & 786 & 200.00 & 54 & 213.05 & 60 \\
\hline 182.05 & 127968 & 192.00 & 881 & 200.30 & 36 & 213.75 & 23 \\
\hline 183.05 & 16728 & 192.95 & 361 & 202.60 & 51 & 215.15 & 24 \\
\hline 184.10 & 1158 & 193.20 & 191 & 203.30 & 28 & 218.25 & 49 \\
\hline
\end{tabular}

\section{Calculation of the Deuterium Incorporation for Experiment Performed in $\left(\mathrm{CH}_{3}\right)_{2} \mathrm{CDOH}:{ }^{22}$}

\begin{tabular}{|c|c|c|c|c|c|c|}
\hline \# of Deuterium Atoms & 0 & 1 & 2 & 3 & 4 & \multirow{5}{*}{$\begin{array}{c}(\mathrm{M}+1) / \mathrm{M} \text { not labeled: } \\
0.16\end{array}$} \\
\hline & $M$ & $M+1$ & $M+2$ & $M+3$ & $M+4$ & \\
\hline Molecular Ions & 196 & 197 & 198 & 199 & 200 & \\
\hline Abund. Unlabeled & 185088 & 30272 & 2306 & 130 & & \\
\hline Abund. Labeled & 13718 & 140512 & 24168 & 2093 & 54 & \\
\hline Relative Abund. Unlabeled & 100 & 16.36 & 1.25 & 0.07 & & \\
\hline Relative Abund. Labeled & 9.76 & 100 & 17.20 & 1.49 & & \\
\hline $\begin{array}{l}\text { unlabeled: } \\
\text { difference: }\end{array}$ & 9.76 & $\begin{array}{c}1.60 \\
98.40 \\
\end{array}$ & & & & $(9.76 * 0.16)=1.60$ \\
\hline $\begin{array}{l}\text { D-1 } \\
\text { difference }\end{array}$ & & 98.40 & $\begin{array}{c}16.09 \\
1.11 \\
\end{array}$ & & & $(98.40 * 0.16)=16.09$ \\
\hline $\begin{array}{l}\mathbf{D}-2 \\
\text { difference }\end{array}$ & & & 1.11 & $\begin{array}{l}0.18 \\
1.31 \\
\end{array}$ & & $(1.11 * 0.16)=0.18$ \\
\hline D-3 & & & & 1.31 & & \\
\hline Percent Distribution & 8.8 & 89.0 & 1.0 & 1.2 & & \\
\hline
\end{tabular}


Calculation of the Deuterium Incorporation for the Experiment Performed in $\left(\mathrm{CH}_{3}\right)_{2} \mathrm{CDOH}$ by ${ }^{1} \mathrm{H}$ NMR:

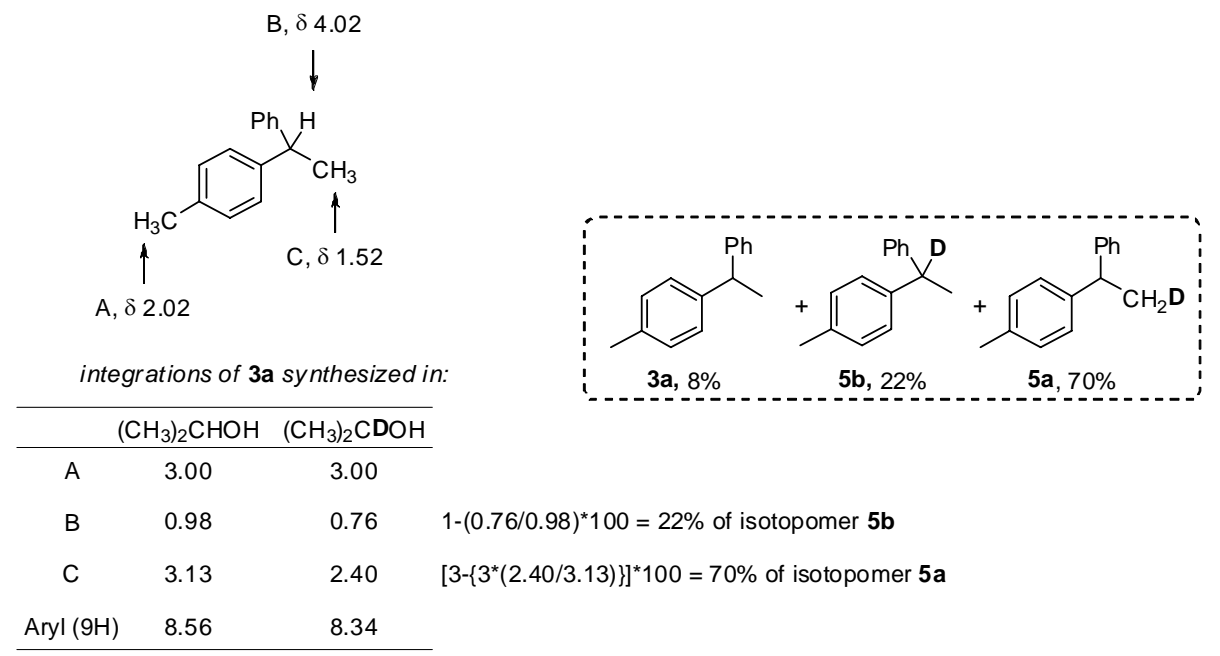

\section{GC/MS Data for 4-methylstyrene (1a):}

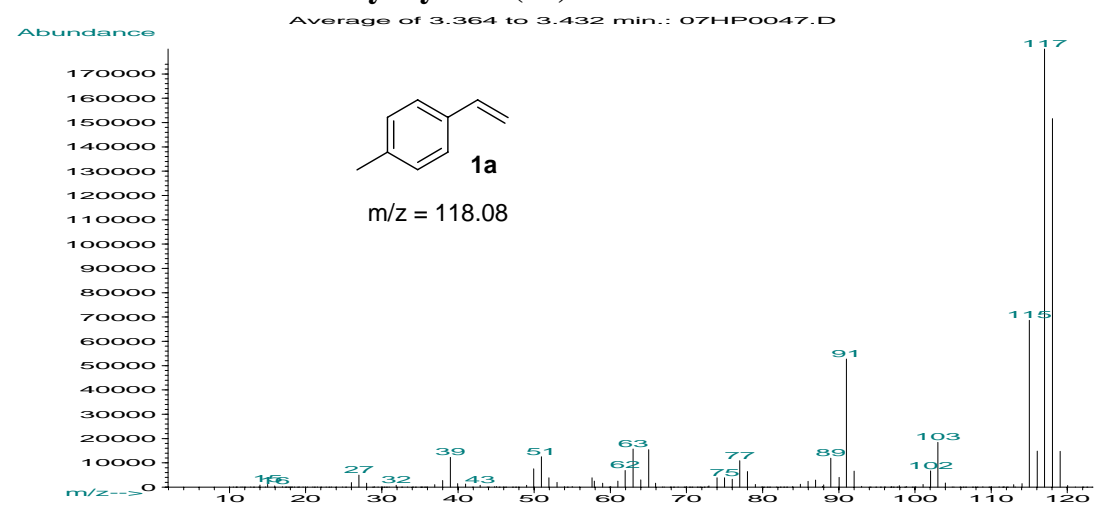

$\begin{array}{lccccccc}m / z & \text { abund. } & m / z & \text { abund. } & m / z & \text { abund. } & m / z & \text { abund. } \\ 65.05 & 15395 & 71.40 & 25 & 79.90 & 100 & 86.95 & 2954 \\ 65.95 & 1601 & 71.75 & 46 & 80.10 & 20 & 87.85 & 322 \\ 66.85 & 89 & 72.30 & 15 & 80.60 & 11 & 88.00 & 900 \\ 67.05 & 72 & 72.80 & 179 & 80.90 & 14 & 88.95 & 11877 \\ 67.85 & 40 & 72.95 & 487 & 81.80 & 54 & 90.05 & 4033 \\ 68.30 & 27 & 74.00 & 3887 & 82.30 & 16 & 91.00 & 52700 \\ 68.90 & 87 & 75.00 & 3895 & 82.75 & 28 & 92.00 & 6589 \\ 69.70 & 12 & 76.00 & 3241 & 83.15 & 29 & 93.00 & 379 \\ 69.95 & 146 & 77.00 & 10869 & 83.95 & 296 & 94.10 & 34 \\ 70.40 & 32 & 78.00 & 6434 & 84.95 & 1185 & 94.85 & 13 \\ 70.70 & 20 & 79.05 & 1084 & 85.95 & 2353 & 95.45 & 13 \\ & & & & & & & \\ m / z & a b u n d . & m / z & a b u n d . & m / z & a b u n d . & m / z & a b u n d . \\ 96.00 & 45 & 102.05 & 6674 & 108.90 & 194 & 116.05 & 14853 \\ 96.80 & 26 & 103.00 & 18441 & 109.70 & 21 & 117.00 & 183332 \\ 96.95 & 156 & 104.00 & 1726 & 110.00 & 281 & 118.05 & 151645 \\ 97.15 & 14 & 104.90 & 99 & 111.05 & 141 & 119.05 & 14735 \\ 97.65 & 34 & 105.10 & 63 & 111.50 & 31 & 120.05 & 695 \\ 97.95 & 582 & 105.90 & 15 & 111.70 & 142 & 121.05 & 51 \\ 98.65 & 9 & 106.30 & 25 & 112.10 & 46 & 122.05 & 14 \\ 98.90 & 259 & 106.65 & 26 & 112.95 & 1036 & 122.55 & 14 \\ 99.65 & 46 & 107.55 & 26 & 113.15 & 113 & 123.25 & 10 \\ 100.10 & 137 & 107.95 & 69 & 114.05 & 1443 & 123.65 & 21 \\ 101.05 & 1096 & 108.15 & 29 & 115.00 & 68620 & 124.55 & 12\end{array}$


GC/MS Data for 4-methyl styrene (1a) of Reaction Performed in $\left(\mathrm{CH}_{3}\right)_{2} \mathrm{CDOH}$ at 2 Hours:

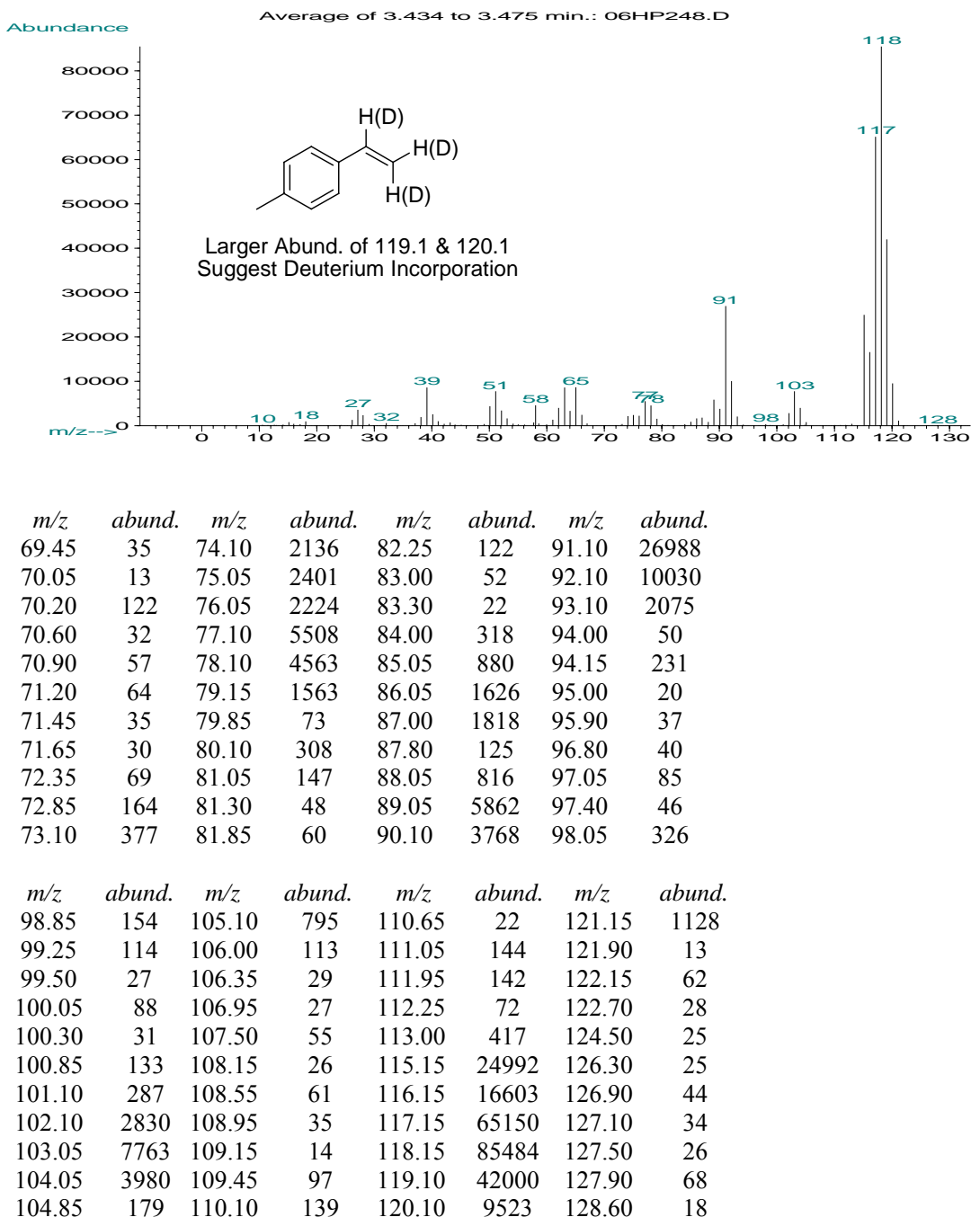

\section{Reductive Coupling of Diene 6:}

6 4-tert-butyl-1-vinylcyclohex-1-ene (6): Diene 6 was synthesized according to a previously reported procedure and the ${ }^{1} \mathrm{H}-\mathrm{NMR}$ spectrum was compared to the previously reported spectrum. ${ }^{23}$

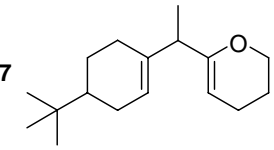

6-(1-(4-tert-butylcyclohex-1-enyl)ethyl)-3,4-dihydro-2H-pyran (7): A three-way joint was fitted to the side arm of an oven dried $100 \mathrm{~mL}$ thick-wall glass pressure vessel equipped with a stir bar. An $\mathrm{O}_{2}$ tank was connected to the three-way joint and $\mathrm{O}_{2}$ was flowed through the vessel. To the vessel, was added $65.2 \mathrm{mg}$ of $\mathrm{MnO}_{2}$ $(0.750 \mathrm{mmol}, 0.750$ equiv. $), 4.30 \mathrm{~mL}$ of 2 -propanol, $0.200 \mathrm{~mL}$ of a $2.00 \mathrm{M}$ solution of (-)-sparteine (0.400 mmol, 0.400 equiv.) in 2-propanol, $164 \mathrm{mg}$ of 4-tert-butyl-1-vinylcyclohex-1-ene (6) $(1.00 \mathrm{mmol}$, 1.00 equiv.), and $560 \mathrm{mg}$ of tributyl(3,4-dihydro-2H-pyran-6-yl)stannane (2f) (1.50 mmol, 1.50 equiv.). The vessel was sealed, pressurized to $25 \mathrm{psi}$, evacuated via water aspiration, and re-pressurized to $25 \mathrm{psi} \mathrm{O}_{2}$. This procedure was repeated three times. The vessel was sealed and the mixture was stirred vigorously for ca. $20 \mathrm{~min}$ at room temperature at $25 \mathrm{psi} \mathrm{O}_{2}$. The vessel was opened and $\mathrm{O}_{2}$ was flowed through the vessel. To the stirred mixture, was added $14.4 \mathrm{mg}$ of $\mathrm{Pd}[(-)$-sparteine $] \mathrm{Cl}_{2}(0.0350 \mathrm{mmol}, 0.0350$ equiv. $)$. The vessel was immediately pressurized to $25 \mathrm{psi}_{2}$ and was sealed. The three-way joint was removed and the reaction mixture was stirred vigorously for $5 \mathrm{~min}$ at room temperature. The mixture was then heated to 
$60{ }^{\circ} \mathrm{C}$ in an oil bath and was stirred vigorously for $18 \mathrm{~h}$. The vessel was removed from the oil bath and cooled to room temperature. To the reaction mixture, was added $5.0 \mathrm{~mL}$ of a $1.00 \mathrm{M}$ solution of aqueous $\mathrm{NaOH}$ and was stirred for $1 \mathrm{~h}^{3}$ The mixture was filtered through Whatman filter paper, rinsed with ca. $10.0 \mathrm{~mL}$ of $\mathrm{Et}_{2} \mathrm{O}$, and was transferred to a separatory funnel. The aqueous layer was extracted three times with $20.0 \mathrm{~mL}$ of $\mathrm{Et}_{2} \mathrm{O}$ and all organic extracts were combined, washed with $40.0 \mathrm{~mL}$ of brine, and dried over $\mathrm{MgSO}_{4}$. The mixture was filtered and the solvent was removed in vacuo. The product was purified via alumina gel flash chromatography by eluting with pentane.

7, Yield: 40\% (105.38 mg and $94.6 \mathrm{mg})\left(1: 1\right.$ mixture of diastereomers); $\mathrm{R}_{\mathrm{f}}=0.38 \mathrm{w} /$ Pentane (alumina), PMA stain. Clear oil; IR (neat) 2988, 2968, 1713, 1466, 1365, 1230, 1071, 913, 770, $649 \mathrm{~cm}^{-1}$; ${ }^{1} \mathrm{H}-\mathrm{NMR}$ $\left(300 \mathrm{MHz}, \mathrm{CDCl}_{3}\right) \delta 0.86(\mathrm{~s}, 9 \mathrm{H}), 1.12(\mathrm{dd}, J=1.6 \mathrm{~Hz}, 7.1 \mathrm{~Hz}, 3 \mathrm{H}), 1.15-1.31(\mathrm{~m}, 1 \mathrm{H}), 1.73-1.88(\mathrm{~m}, 5 \mathrm{H})$, $1.97-2.10(\mathrm{~m}, 5 \mathrm{H}), 2.67(\mathrm{q}, J=6.9 \mathrm{~Hz}, 1 \mathrm{H}), 3.90-4.04(\mathrm{~m}, 2 \mathrm{H}), 4.52(\mathrm{t}, J=3.7 \mathrm{~Hz}, 1 \mathrm{H}), 5.47-5.56(\mathrm{~m}, 1 \mathrm{H})$; ${ }^{13} \mathrm{C}-\mathrm{NMR}\{1 \mathrm{H}\}\left(75 \mathrm{MHz}, \mathrm{CDCl}_{3}\right): \delta 16.9,17.3,20.6,22.8,24.5,24.6,27.1,27.5,27.9,28.0,32.5,44.3$, $44.4,45.0,45.5,66.4,66.5,95.2,95.3,121.4,121.5,139.6,139.8,157.1 ;$ MS (ESI/APCI) $\mathrm{m} / \mathrm{z}(\mathrm{MH})^{+}$calcd.: 249.2218 obsd. 249.2223 .

\section{Optical Rotation Data Measured in $\mathrm{CH}_{2} \mathrm{Cl}_{2}$ :}

Entry Concentration $(\mathrm{mg} / \mathrm{mL})$




\section{References:}

1. Mandal, S. K.; Sigman, M. S. J. Org. Chem. 2003, 68, 7535-7537.

2. Mueller, J. A.; Jensen, D. R.; Sigman, M. S. J. Am. Chem. Soc. 2002, 124, 82028203.

3. $\quad$ Renaud, P.; Lacote, E.; Quaranta, L. Tetrahedron Lett. 1998, 39, 2123-2126.

4. Mertins, K.; Iovel, I.; Kischel, J.; Zapf, A.; Beller, M. Adv. Syn. Cat. 2006, 348, 691-695.

5. $\quad$ Arvela, R. K.; Leadbeater, N. E. J. Org. Chem. 2005, 70, 1786-1790.

6. Boczon, W.; Pieczonka, G.; Wiewiorowski, M. Tetrahedron 1977, 33, 2565-2570.

7. Procedure adapted from: Johannes, C. W.; Visser, M. S.; Weatherhead, G. S.; Hoveyda, A. H. J. Am. Chem. Soc. 1998, 120, 8340-8347.

8. Yoshizawa, Y.; Kawaii, S.; Kanauchi, M.; Chida, M.; Mizutani, J. Biosci., Biotechnol., Biochem. 1993, 57, 1572-1574.

9. Procedure adapted from: Powell, D. A.; Maki, T.; Fu, G. C. J. Am. Chem. Soc. 2005, 127, 510-511.

10. Dughera, S. Synthesis 2006, 1117-1122.

11. Kozyrod, R. P.; Morgan, J.; Pinhey, J. T. Aust. J. Chem. 1985, 38, 1147-1153.

12. Conway, J. C.; Quayle, P.; Regan, A. C.; Urch, C. J. Tetrahedron 2005, 61, 11910-11923.

13. Sato, N.; Fukuya, S. J. Chem. Soc., Perkin Trans. 1 2000, 89-95.

14. Seyferth, D.; Stone, F. G. A. J. Am. Chem. Soc. 1957, 79, 515-517.

15. Russell, G. A.; Ngoviwatchai, P.; Tashtoush, H.; Hershberger, J. Organometallics 1987, 6, 1414-1419.

16. Steinhoff, B. A.; Stahl, S. S. J. Am. Chem. Soc. 2006, 128, 4348-4355.

17. Rueping, M.; Nachtsheim, B. J.; Scheidt, T. Org. Lett. 2006, 8, 3717-3719.

18. Kischel, J.; Jovel, I.; Mertins, K.; Zapf, A.; Beller, M. Org. Lett. 2006, 8, 19-22.

19. Stoltz, B. M.; Kano, T.; Corey, E. J. J. Am. Chem. Soc. 2000, 122, 9044-9045.

20. Ehrentraut, A.; Zapf, A.; Beller, M. Adv. Syn. Cat. 2002, 344, 209-217.

21. Tzeng, Y. L.; Yang, P. F.; Mei, N. W.; Yuan, T. M.; Yu, C. C.; Luh, T. Y. J. Org. Chem. 1991, 56, 5289-5293.

22. Lambert, J. B.; Shurvell, H. F.; Lightner, D. A.; Cooks, R. G., Organic Structural Spectroscopy. Prentice-Hall, Inc: Saddle River, NJ, 1998; pp 447-448.

23. Zhang, A.; RajanBabu, T. V. J. Am. Chem. Soc. 2006, 128, 54-55. 


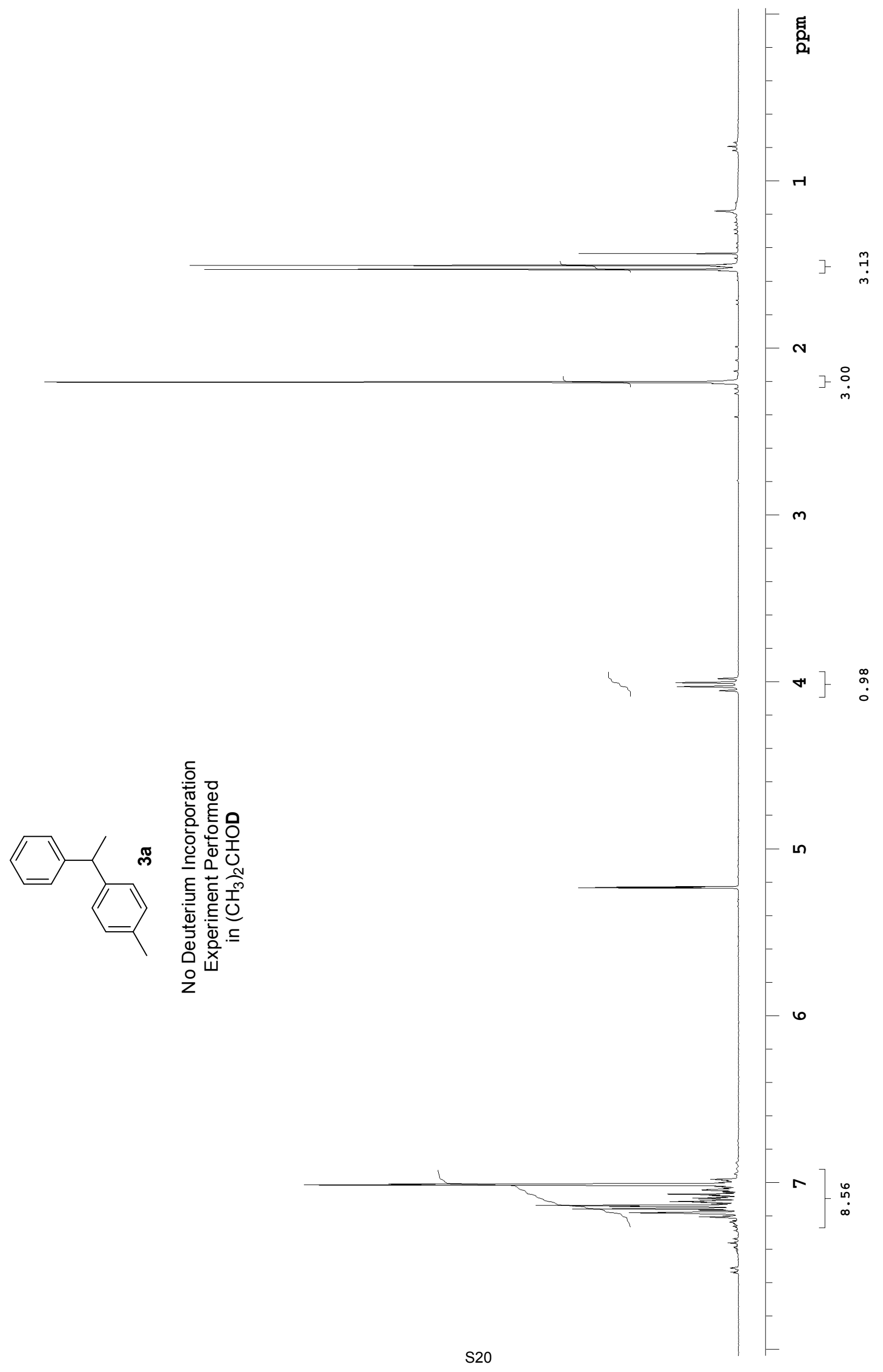




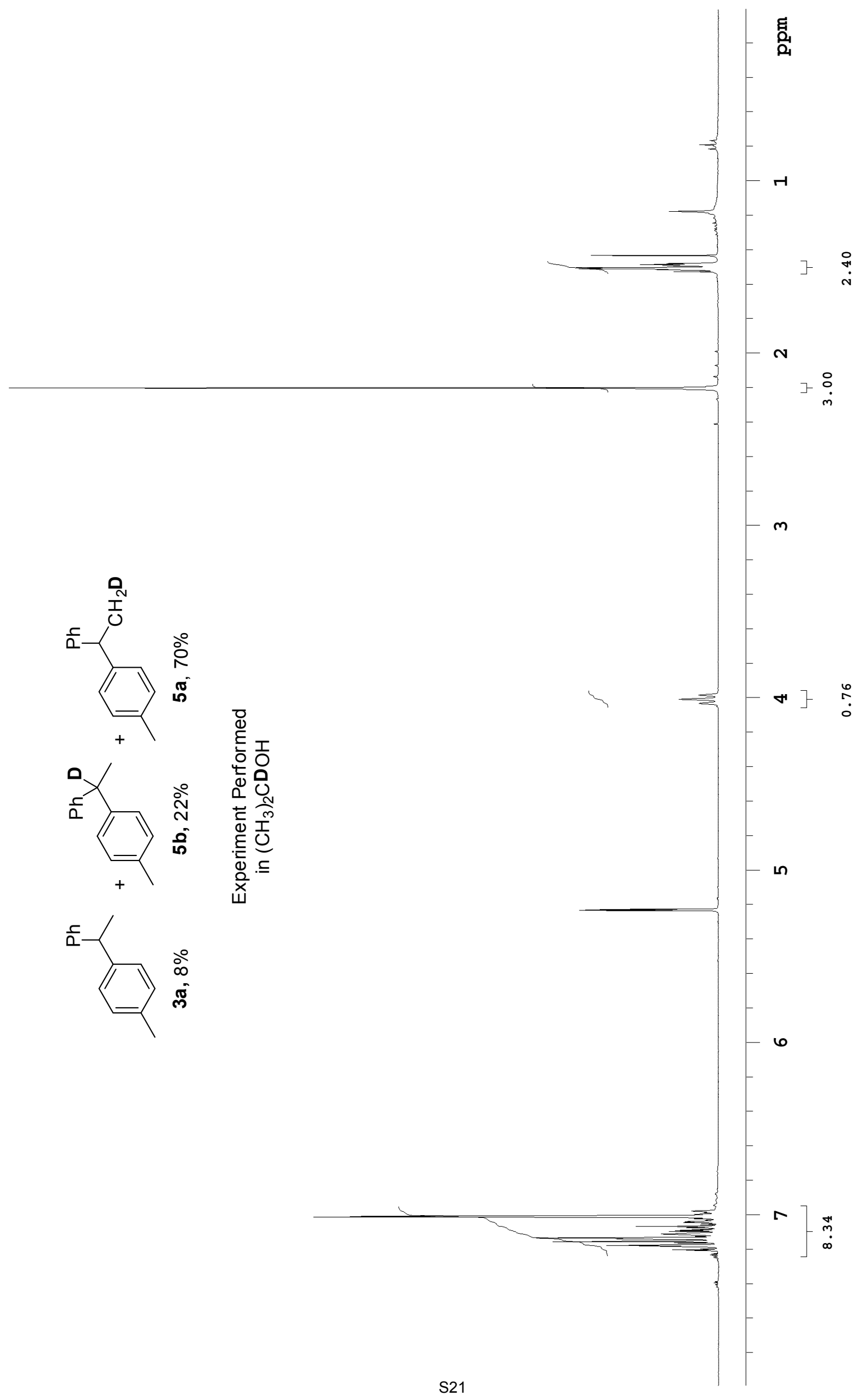




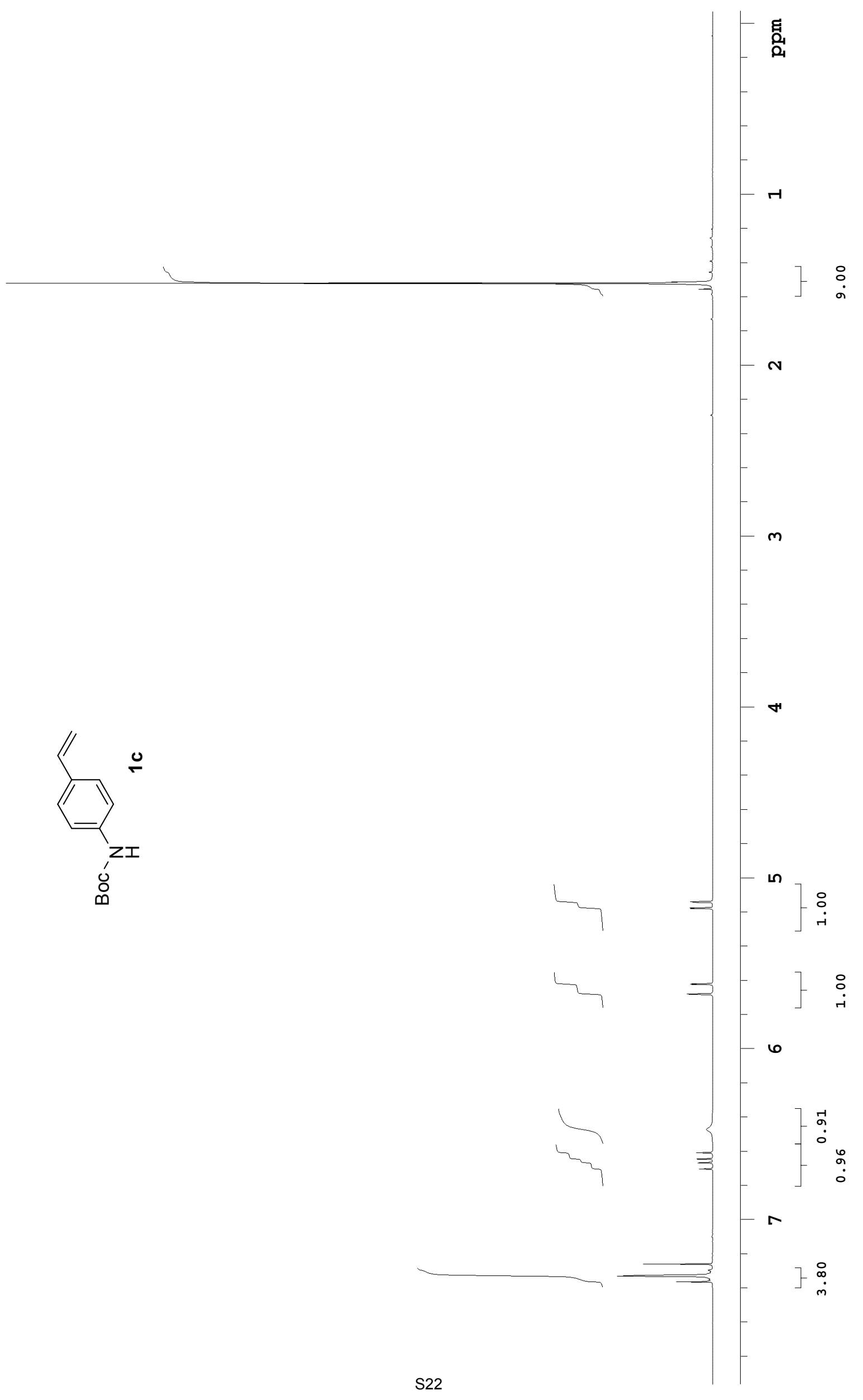




$$
1
$$




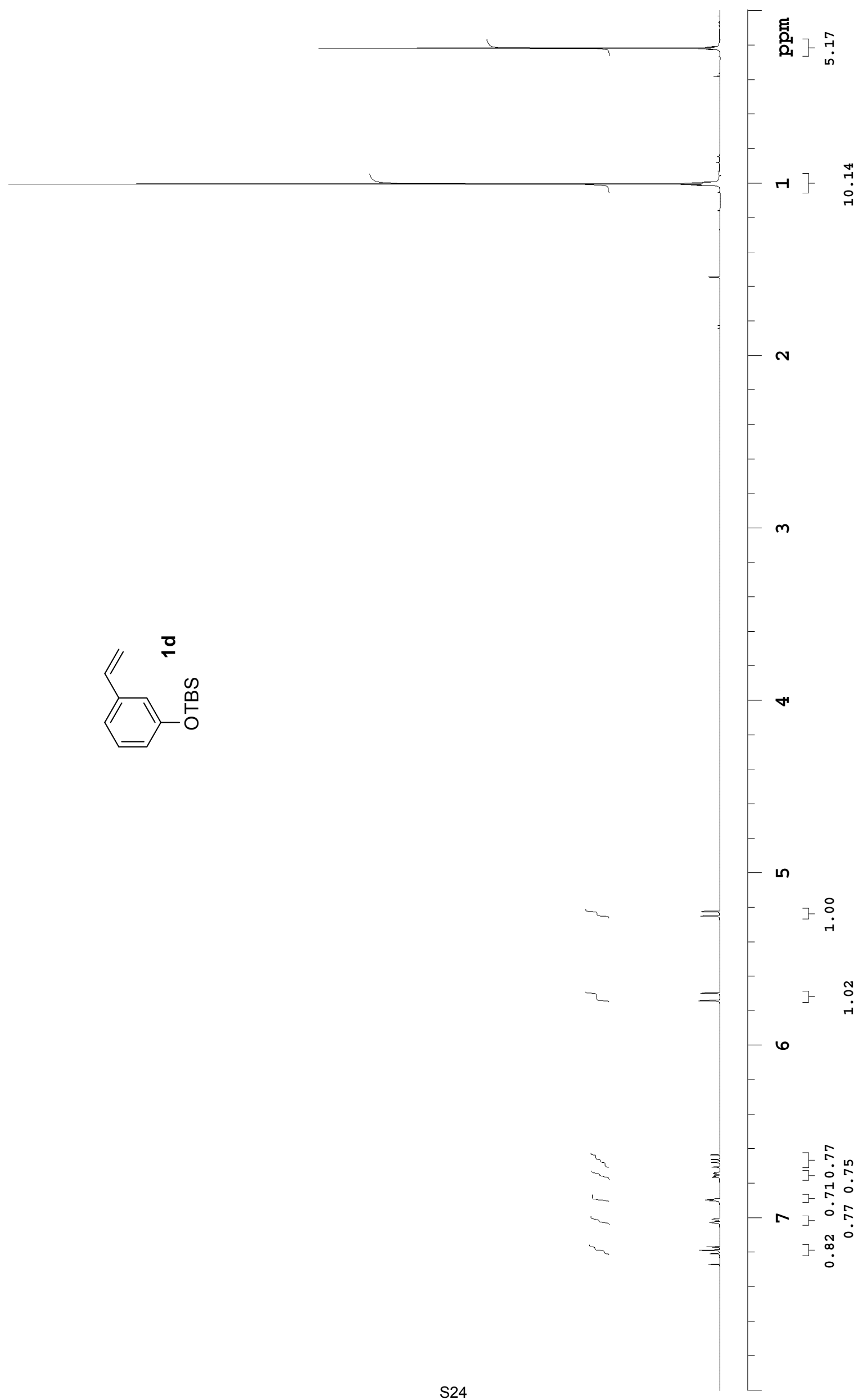




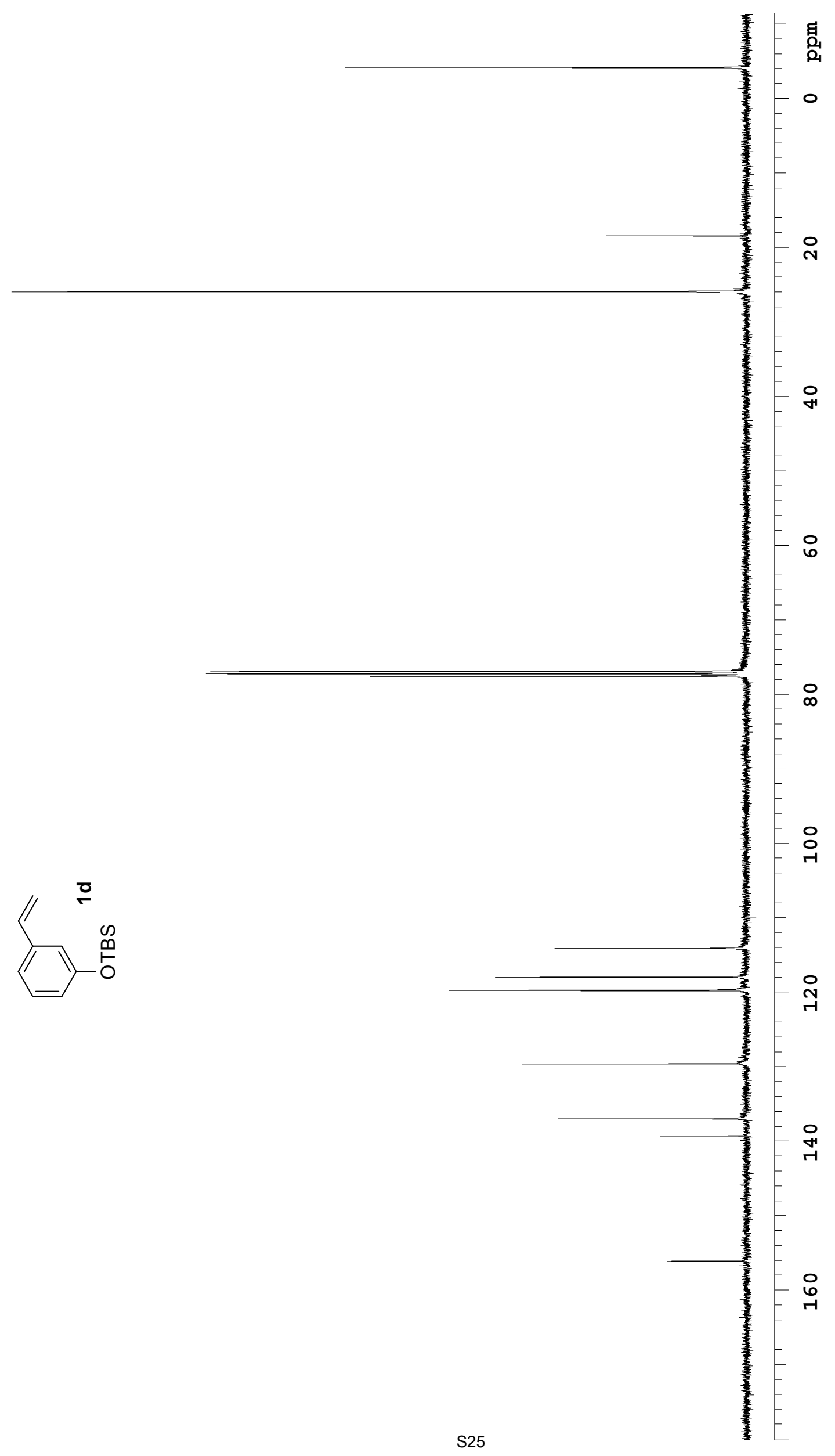




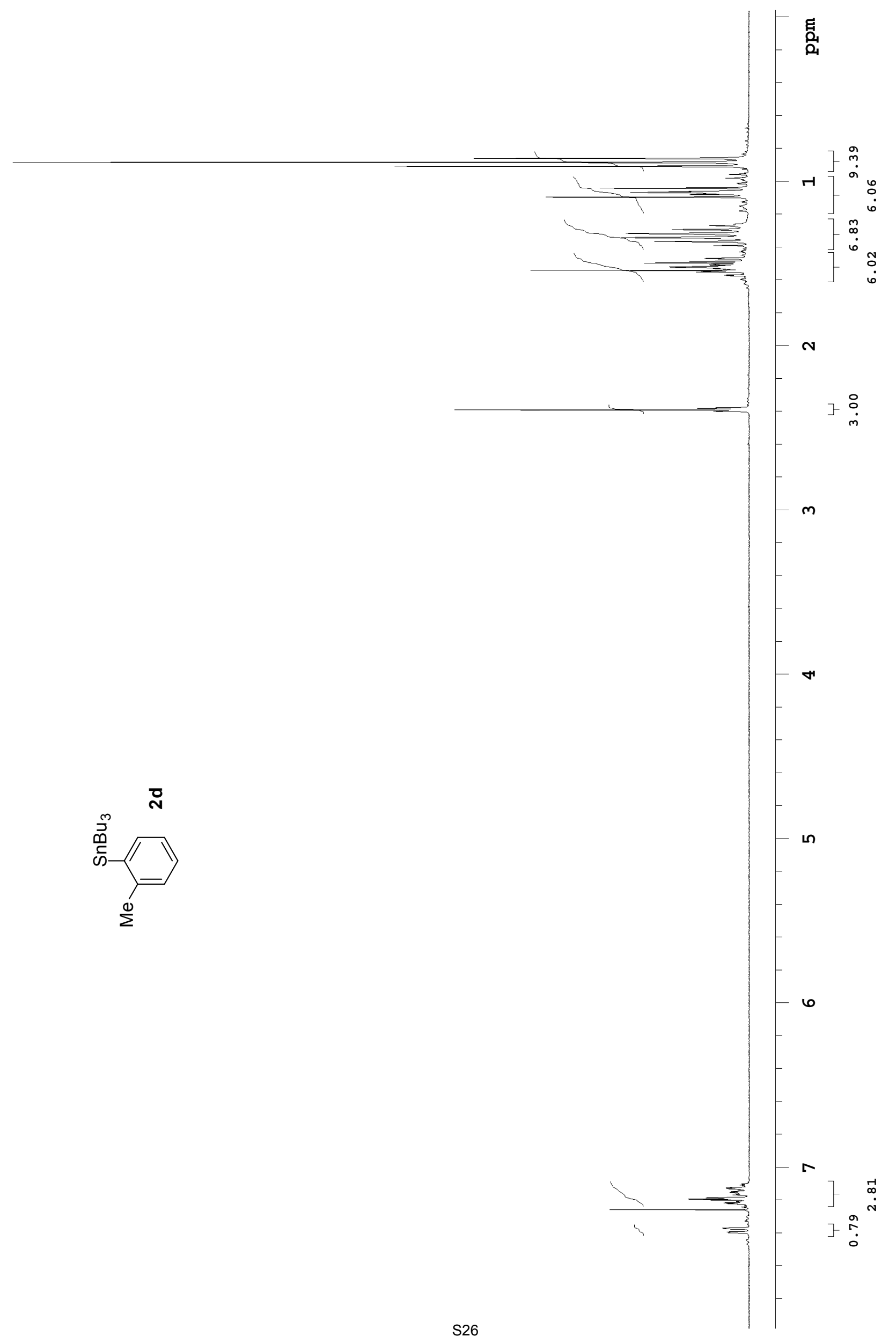




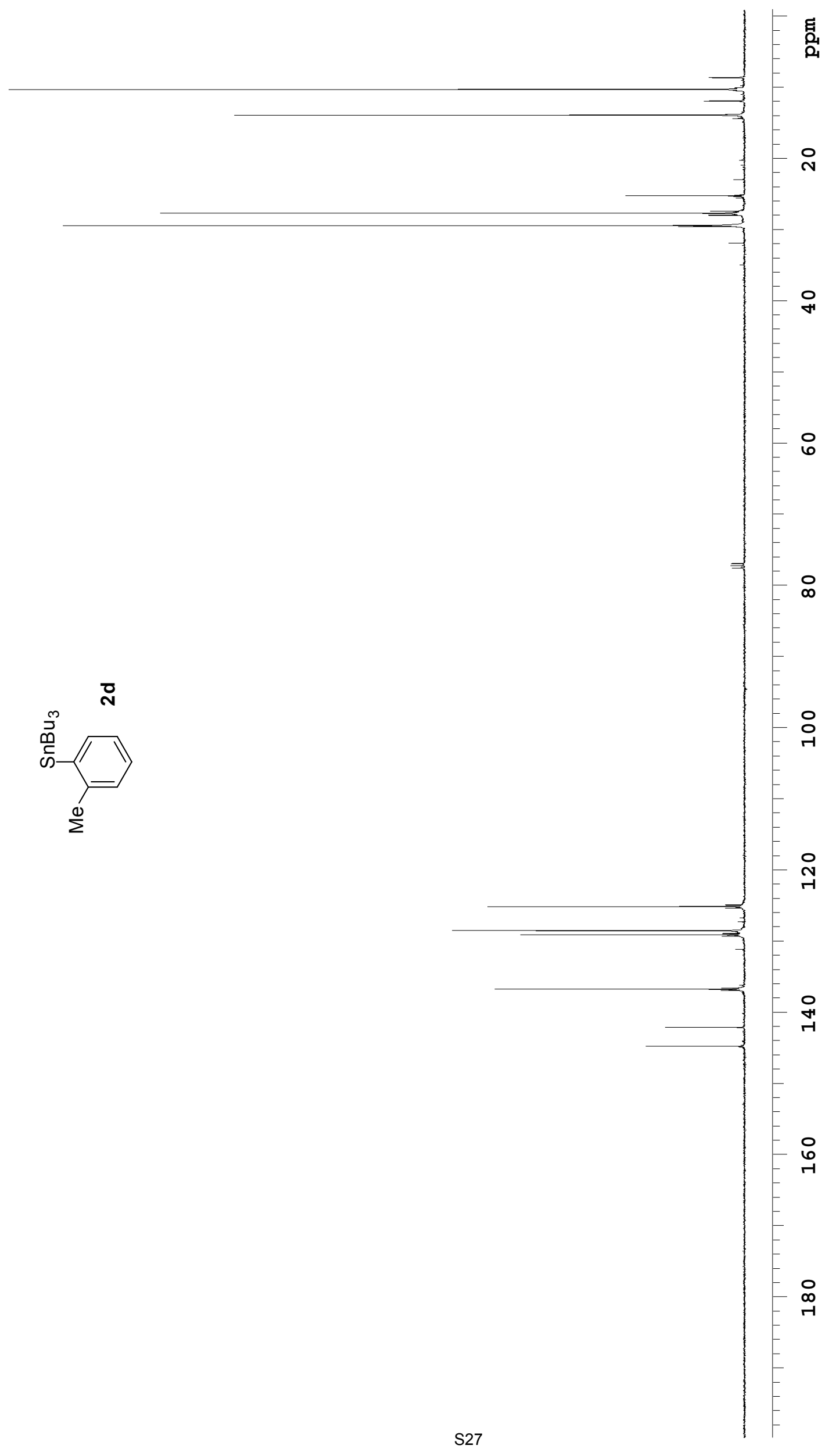




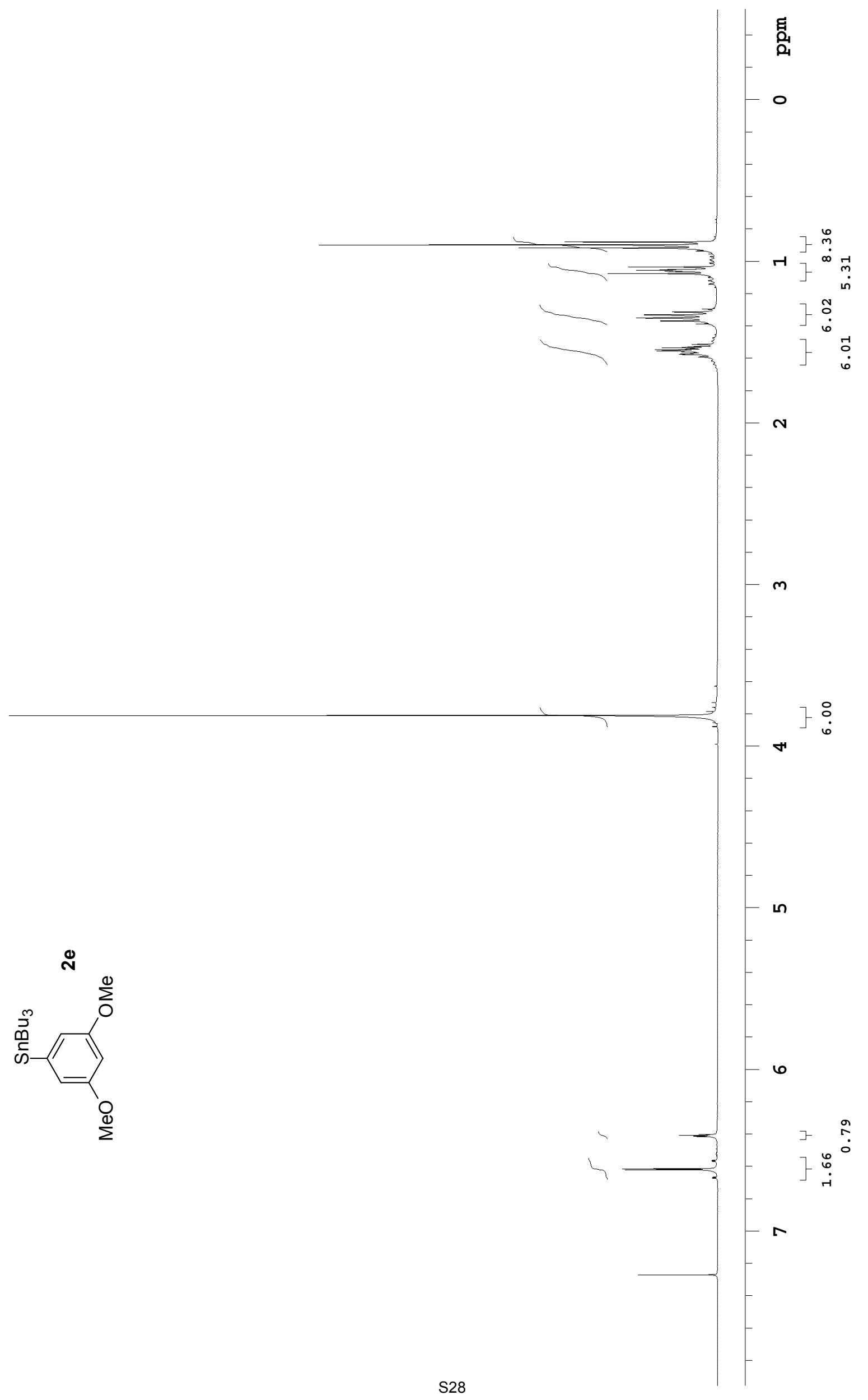




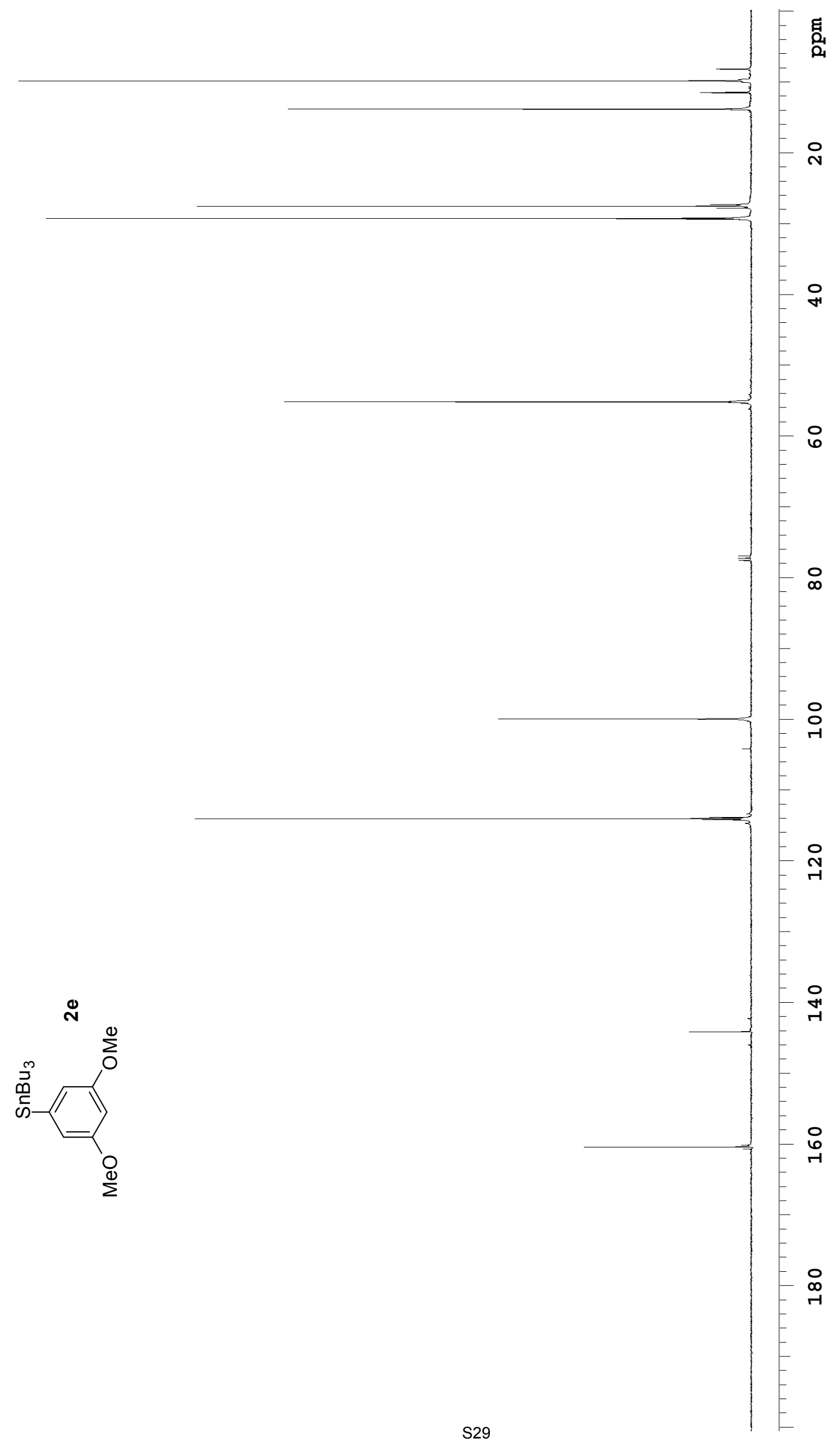




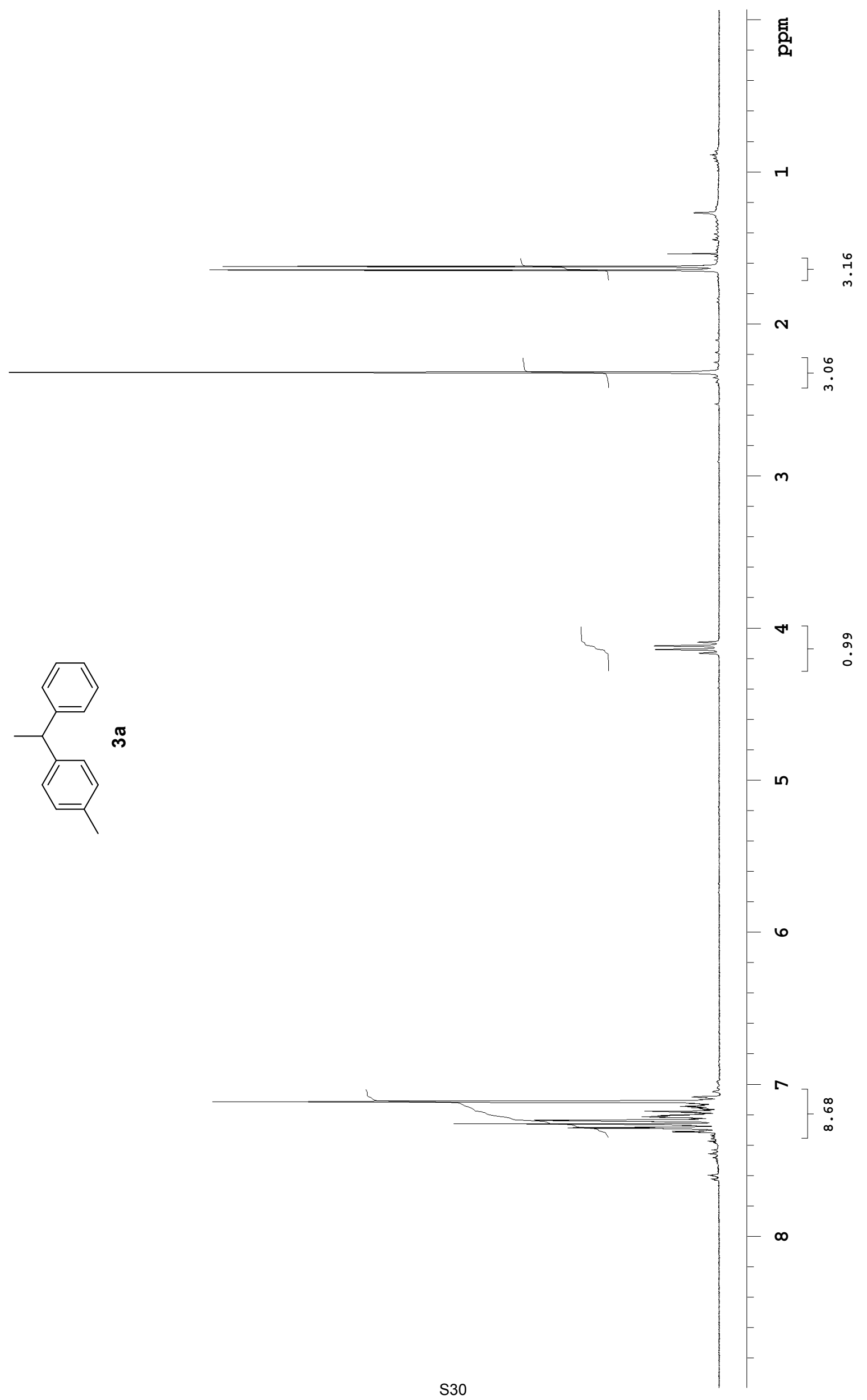




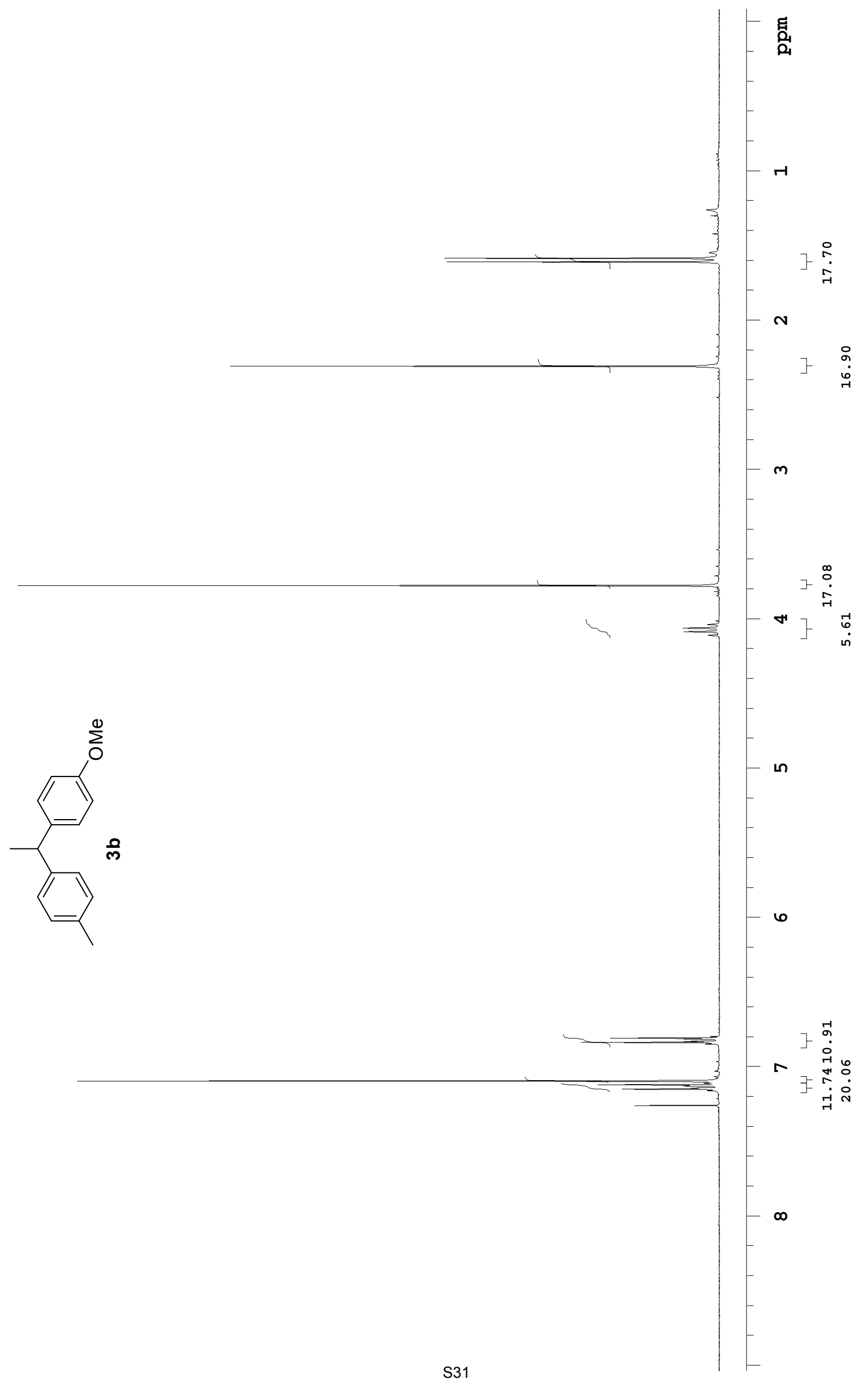




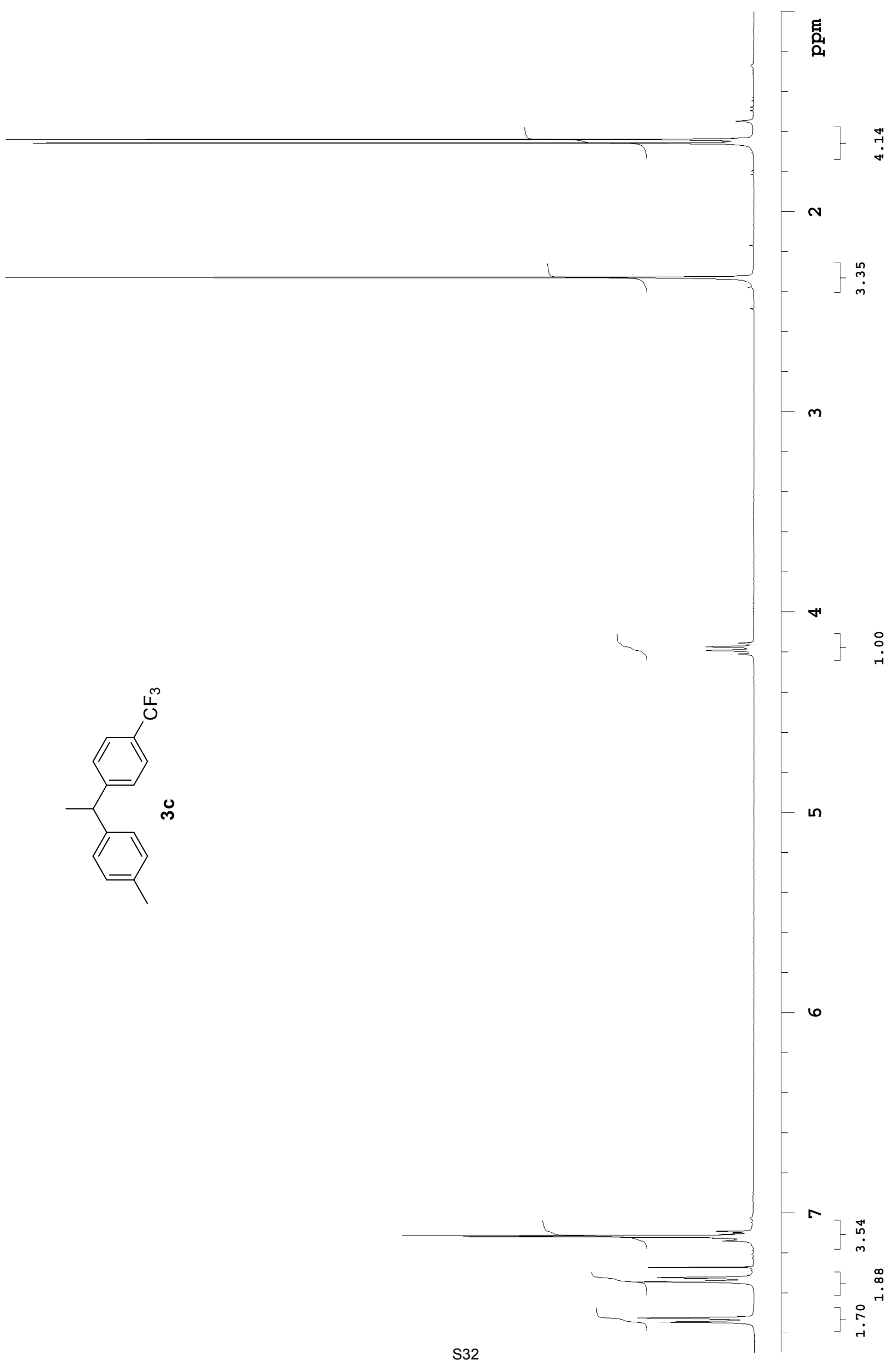




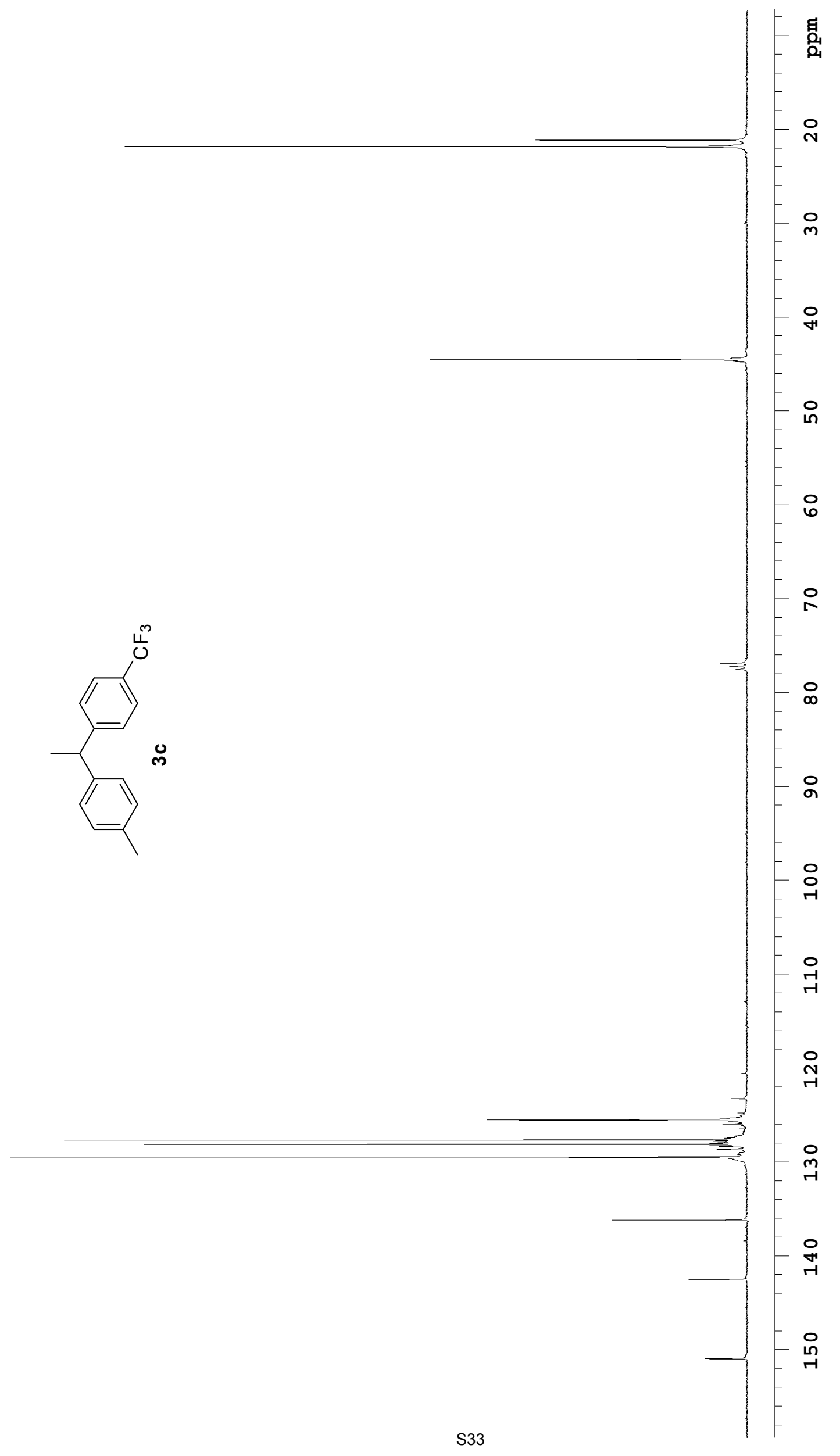




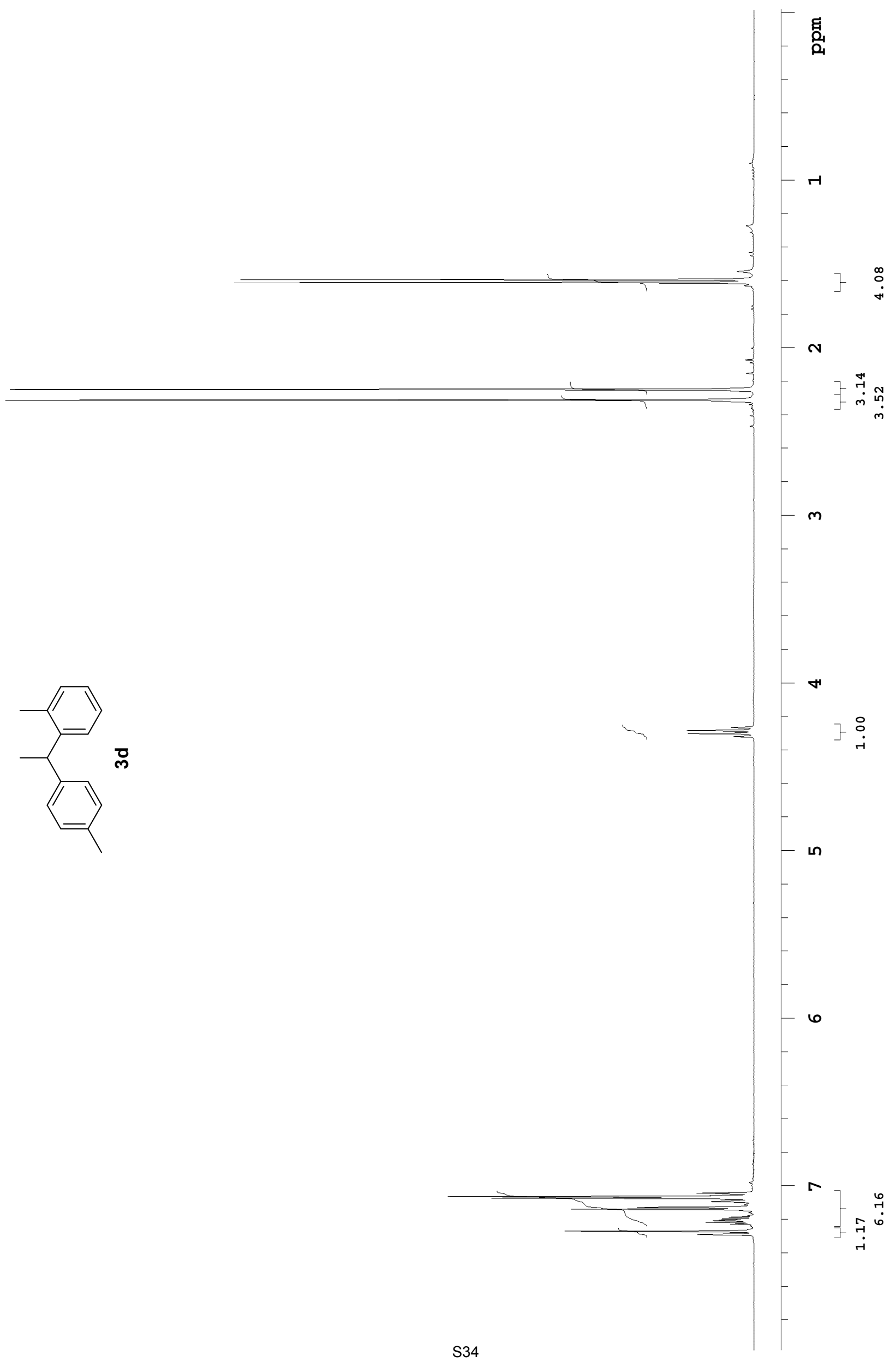




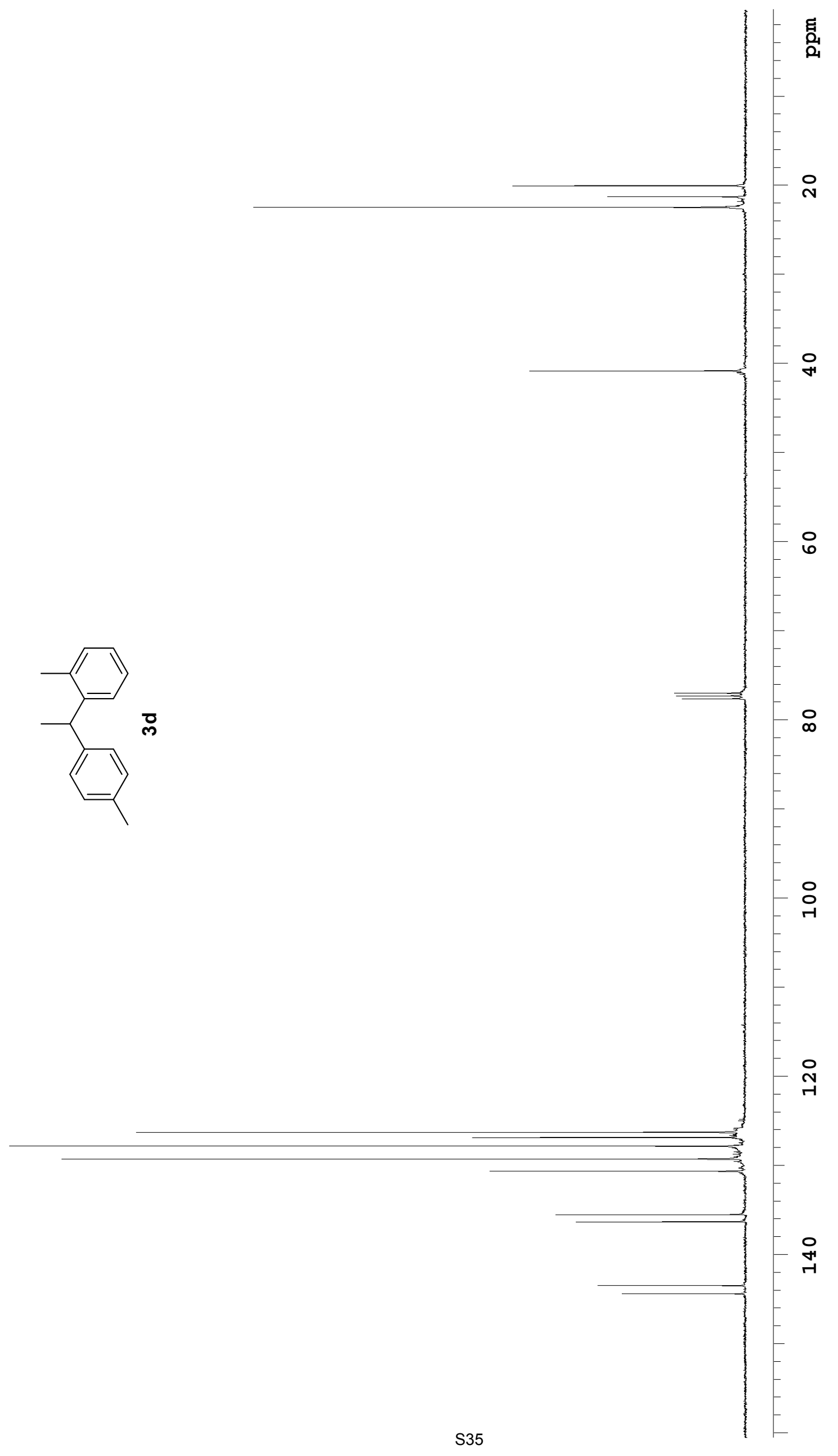




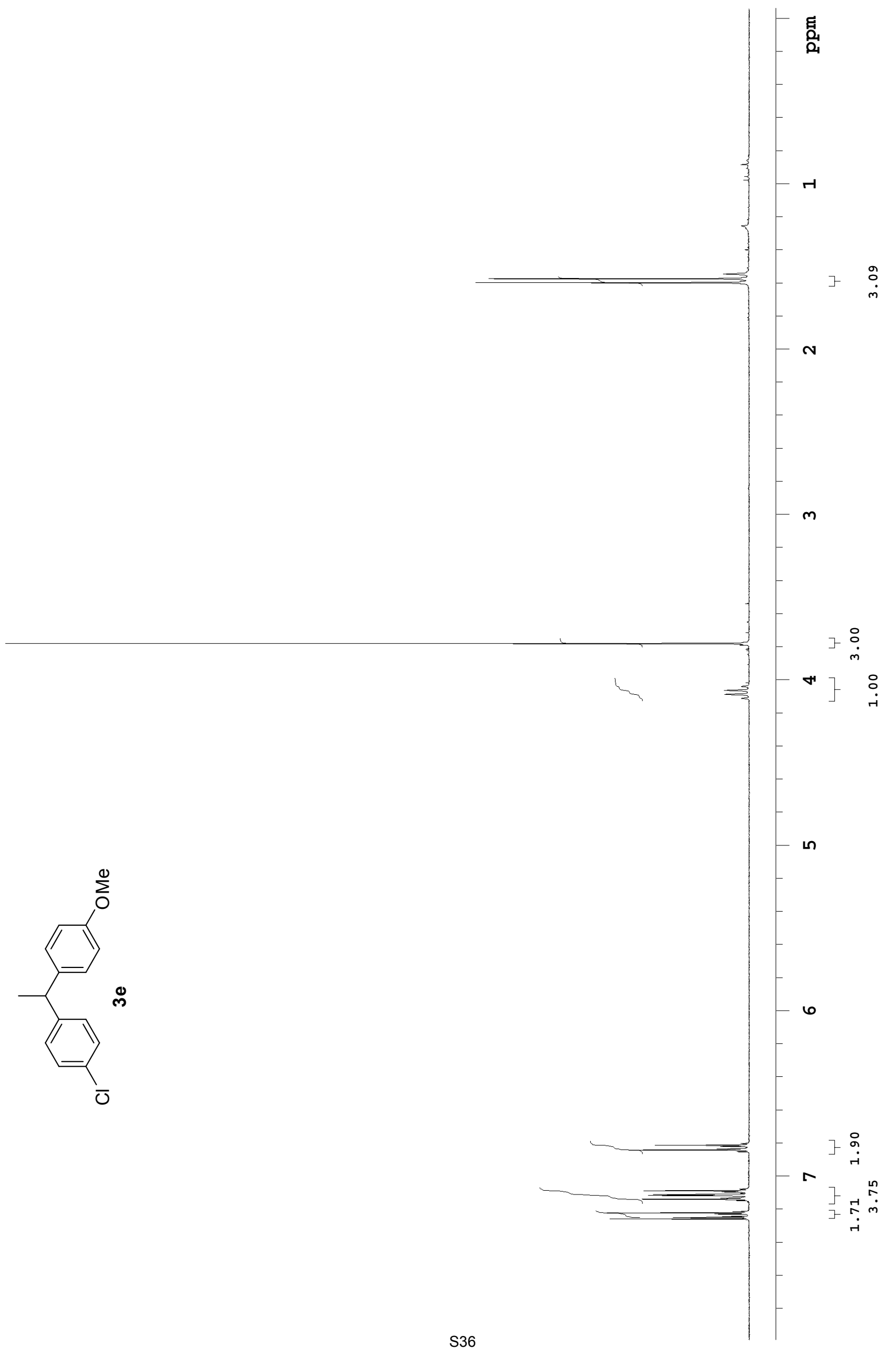




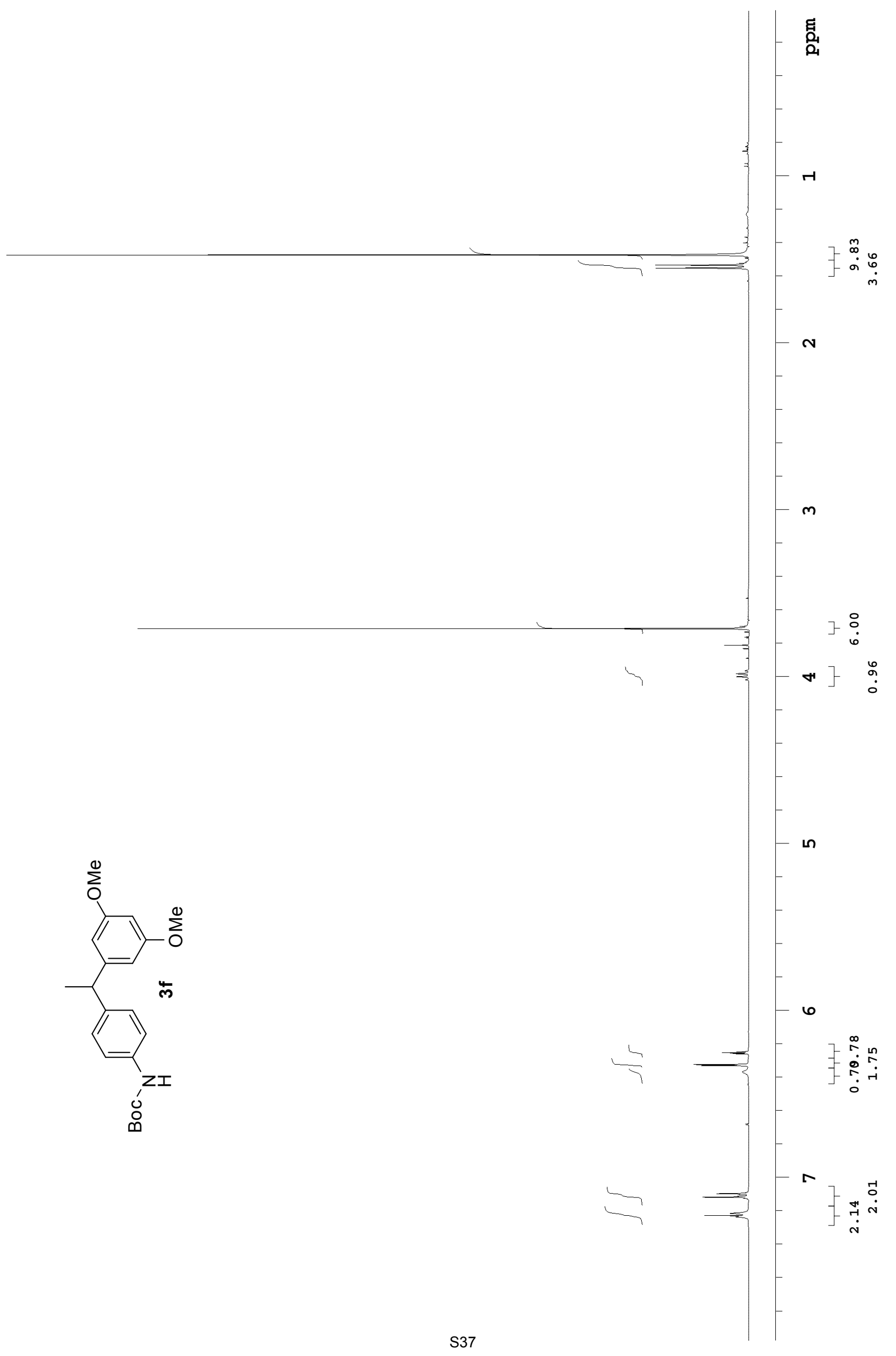




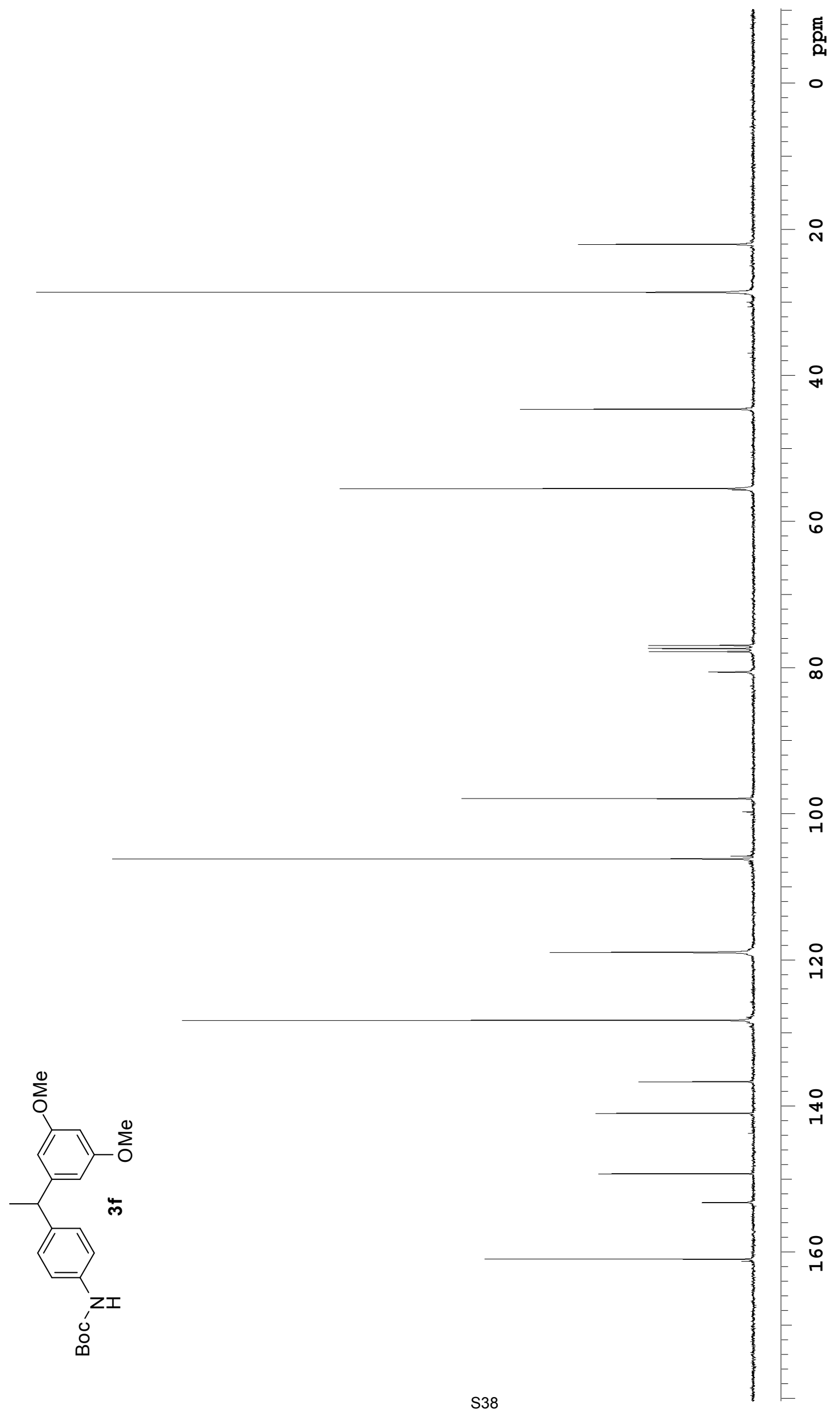




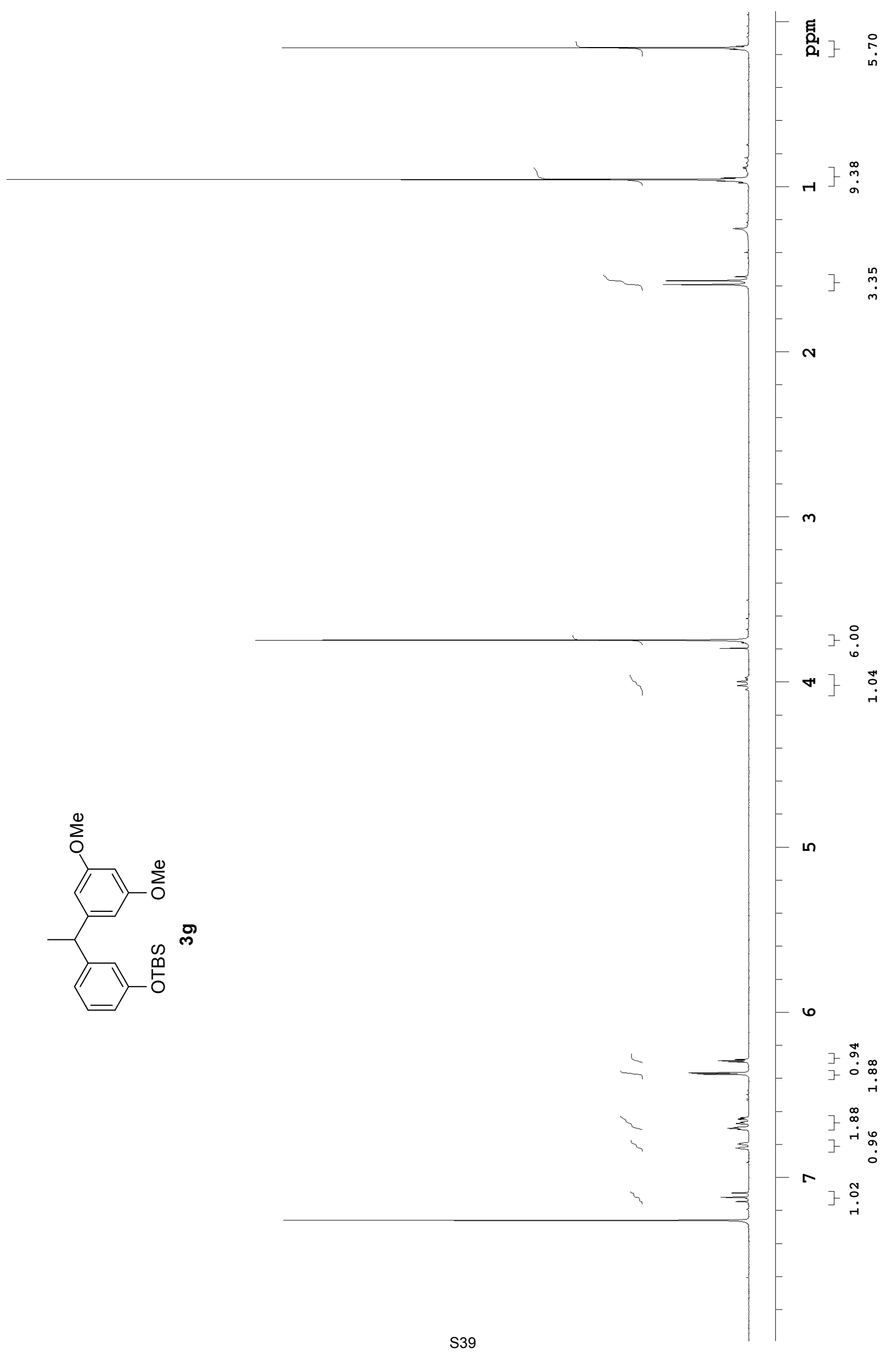




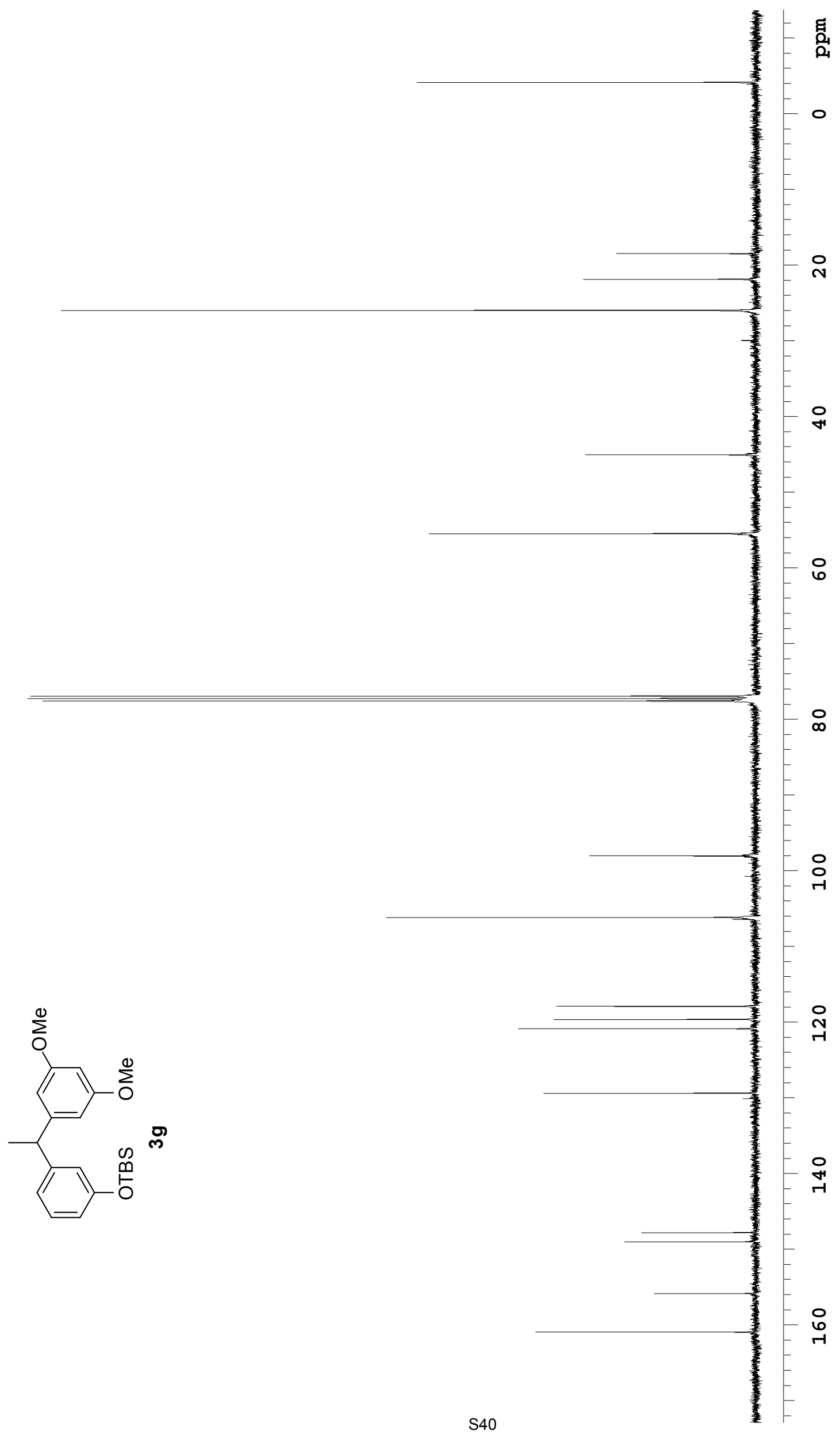




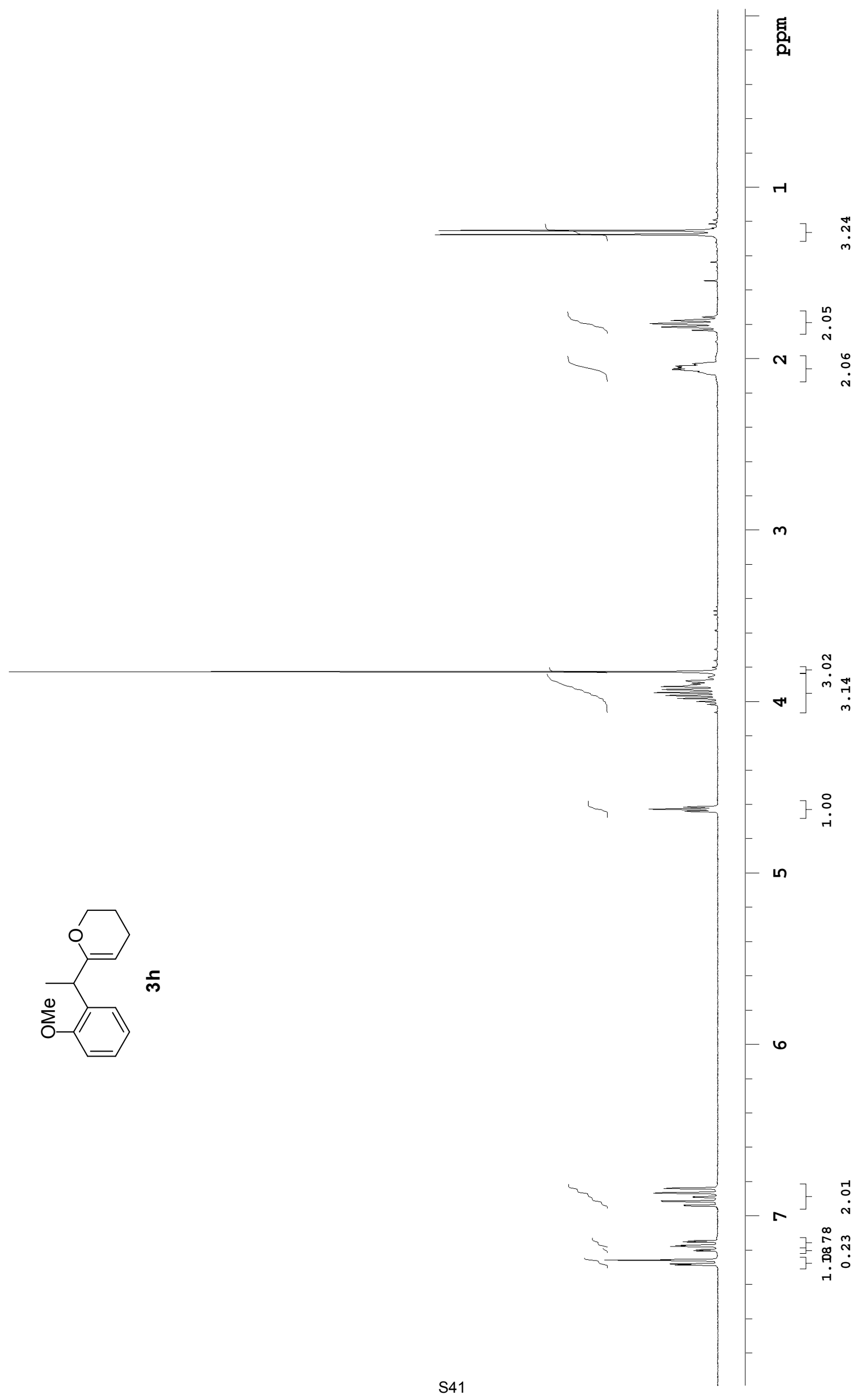




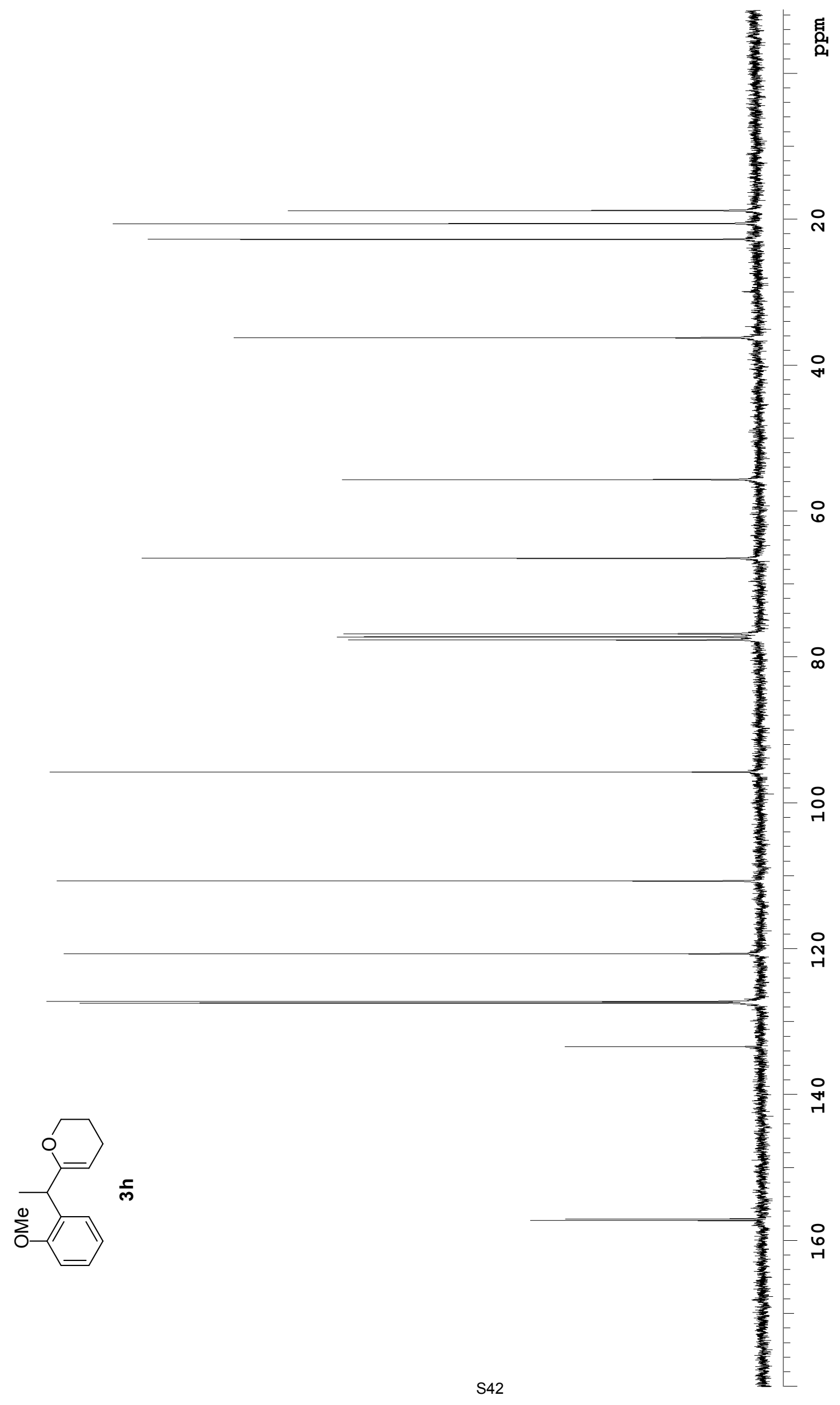




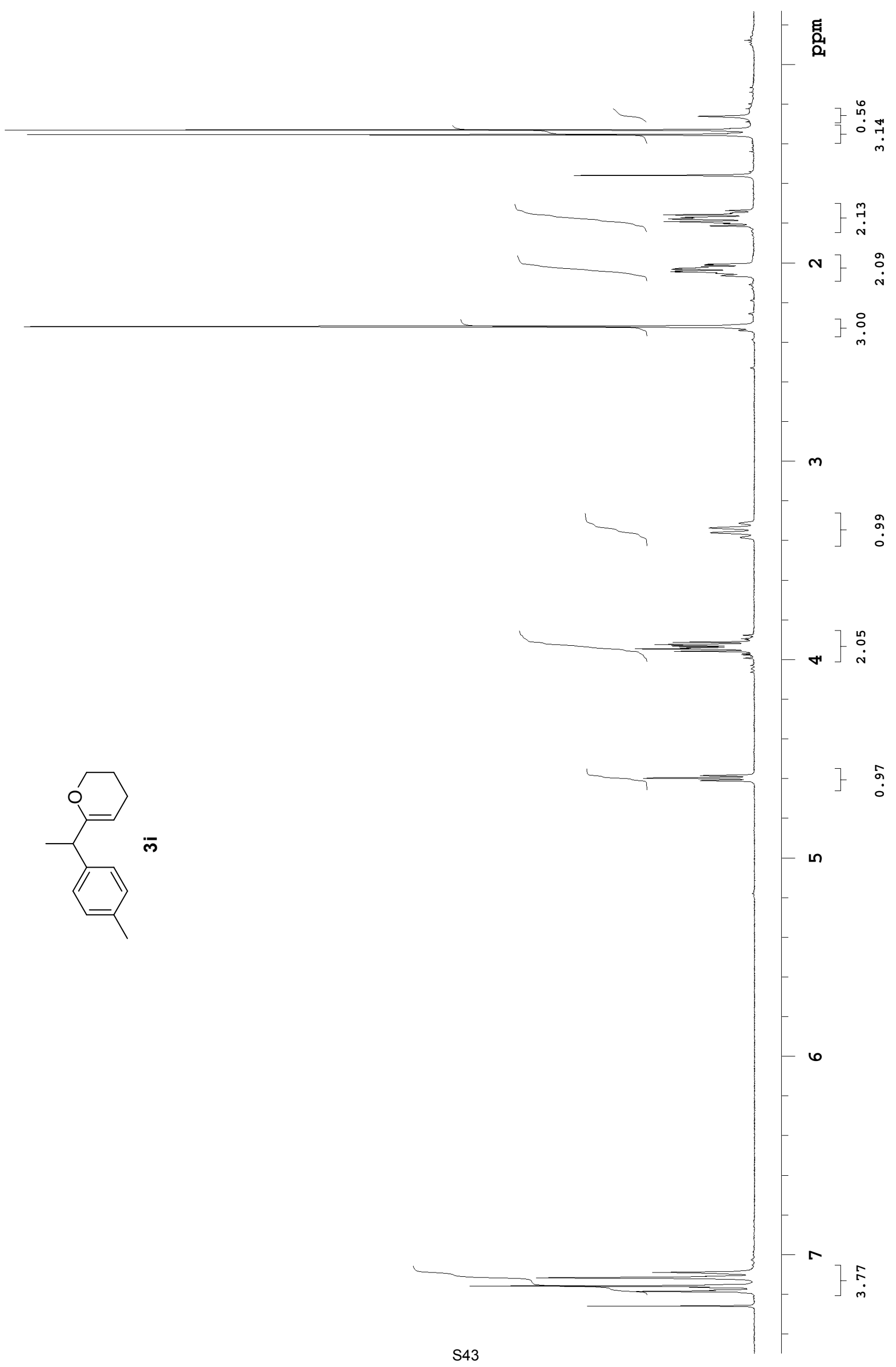




$$
1
$$




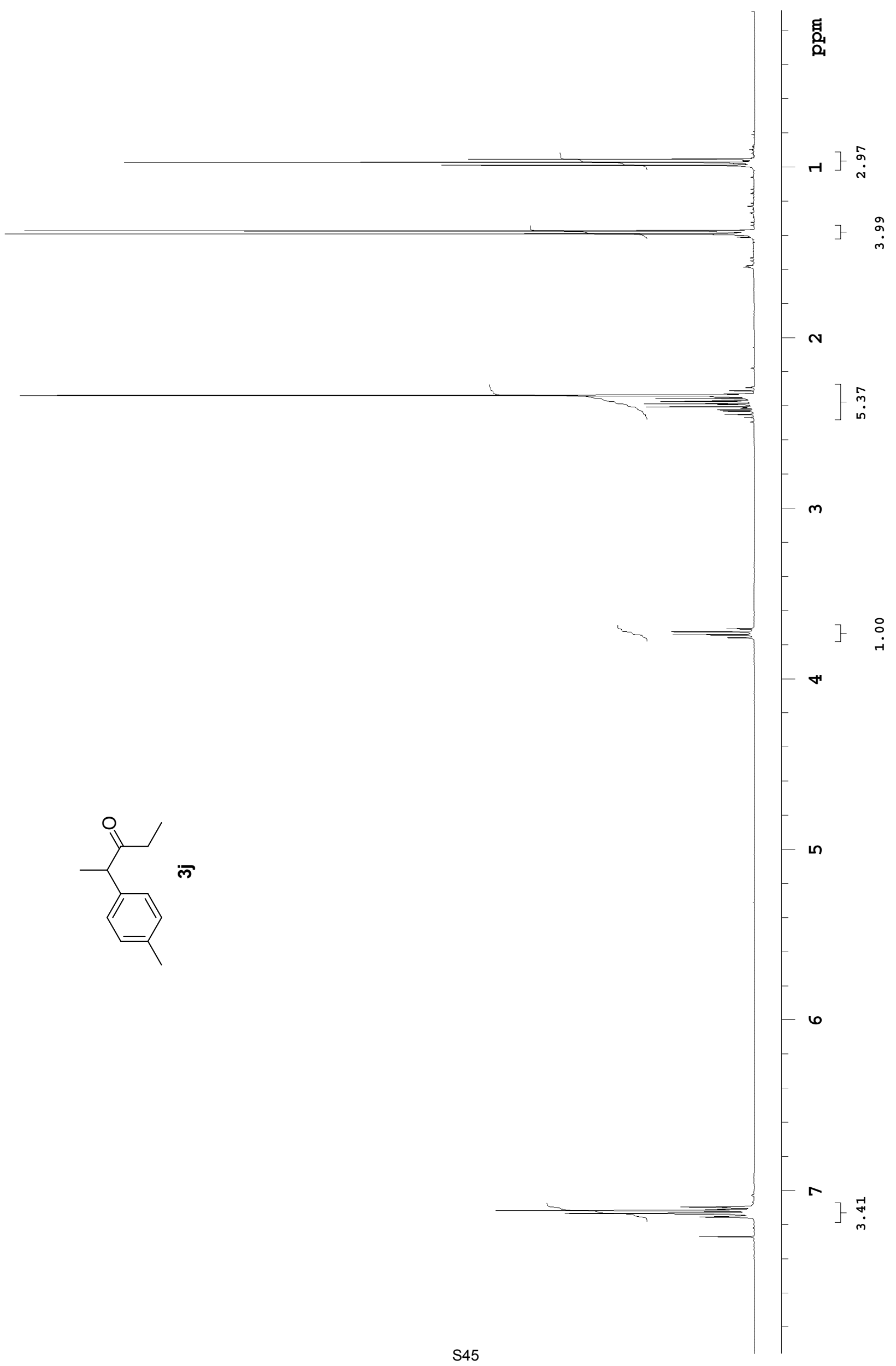




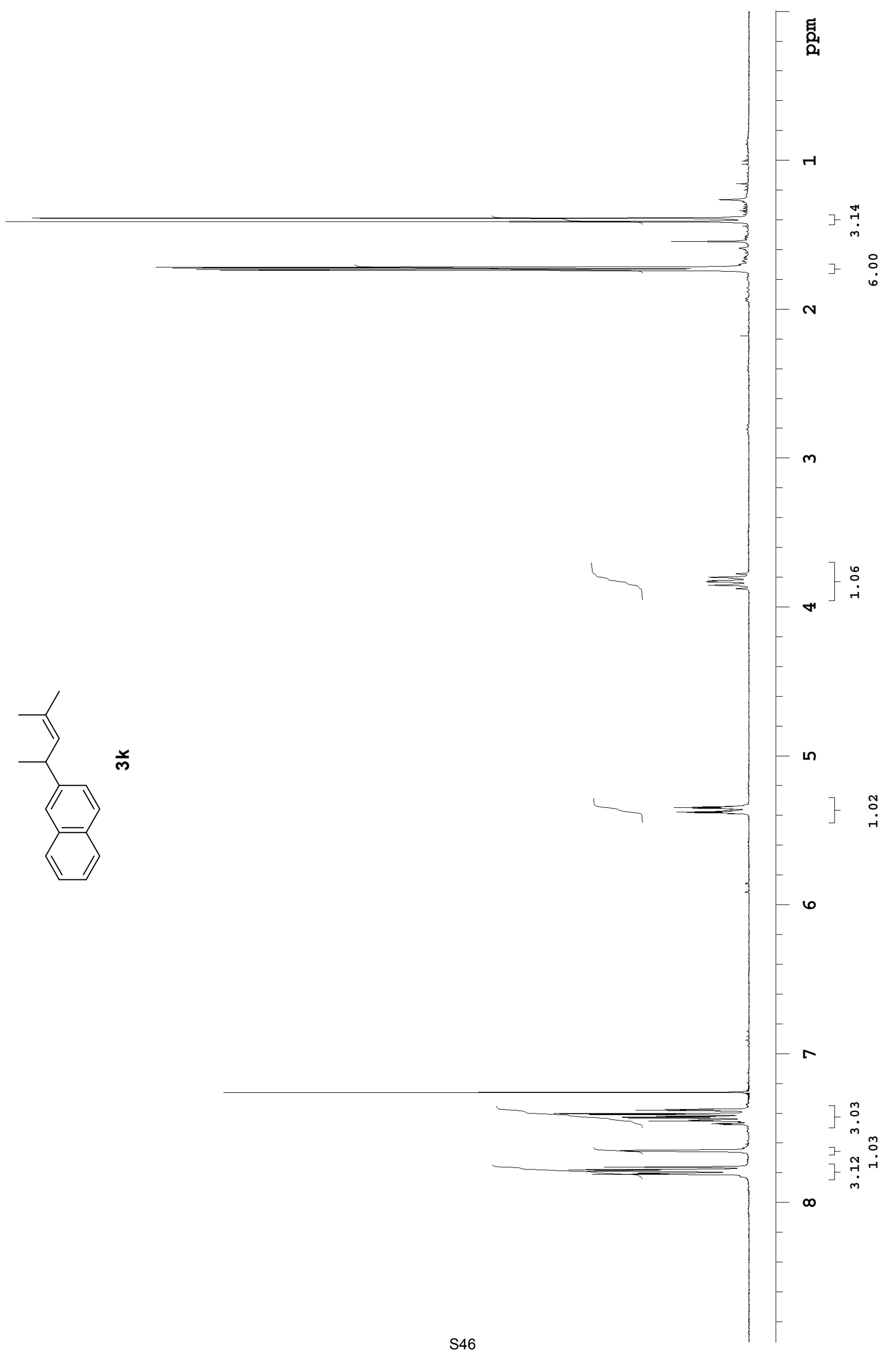




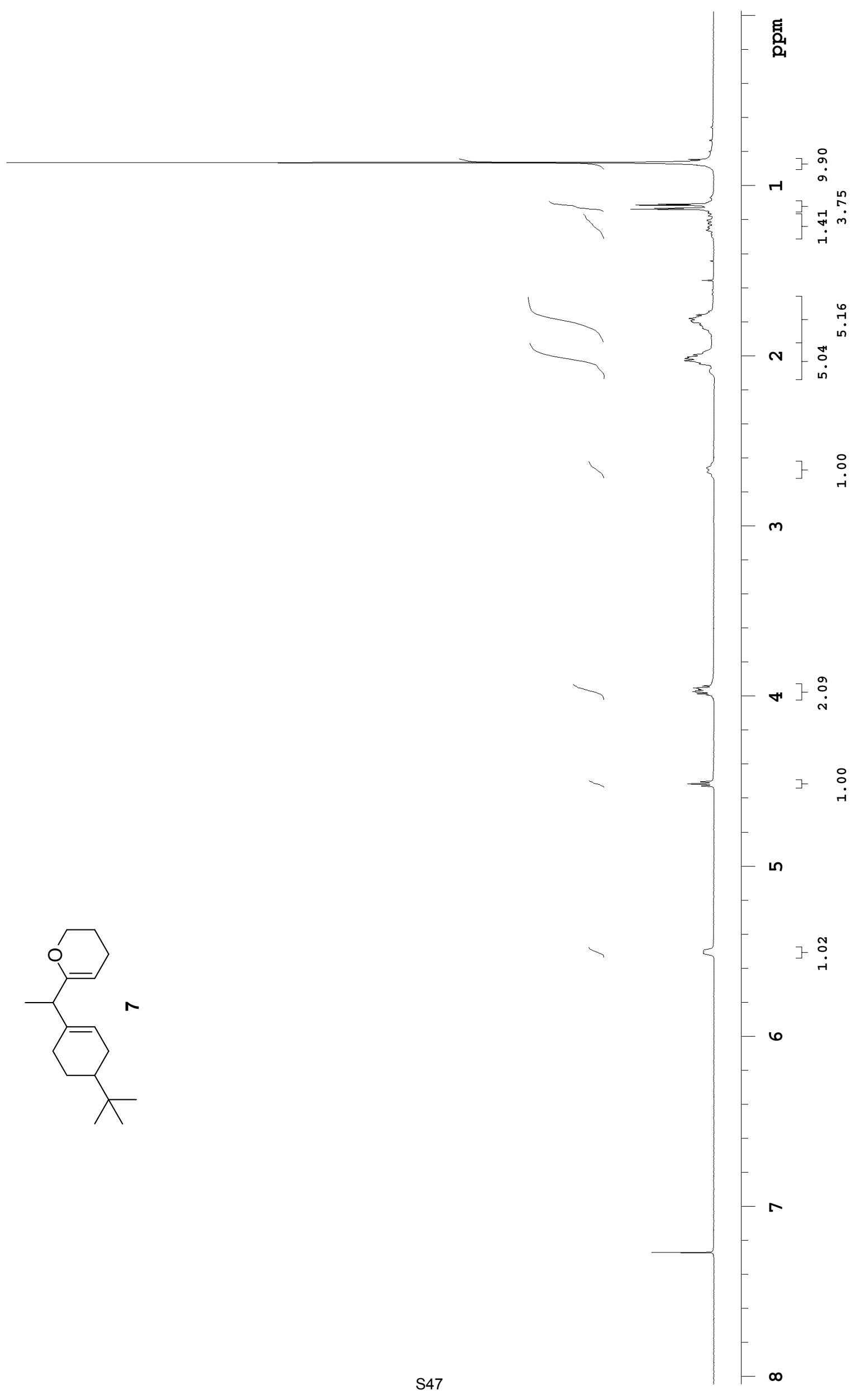




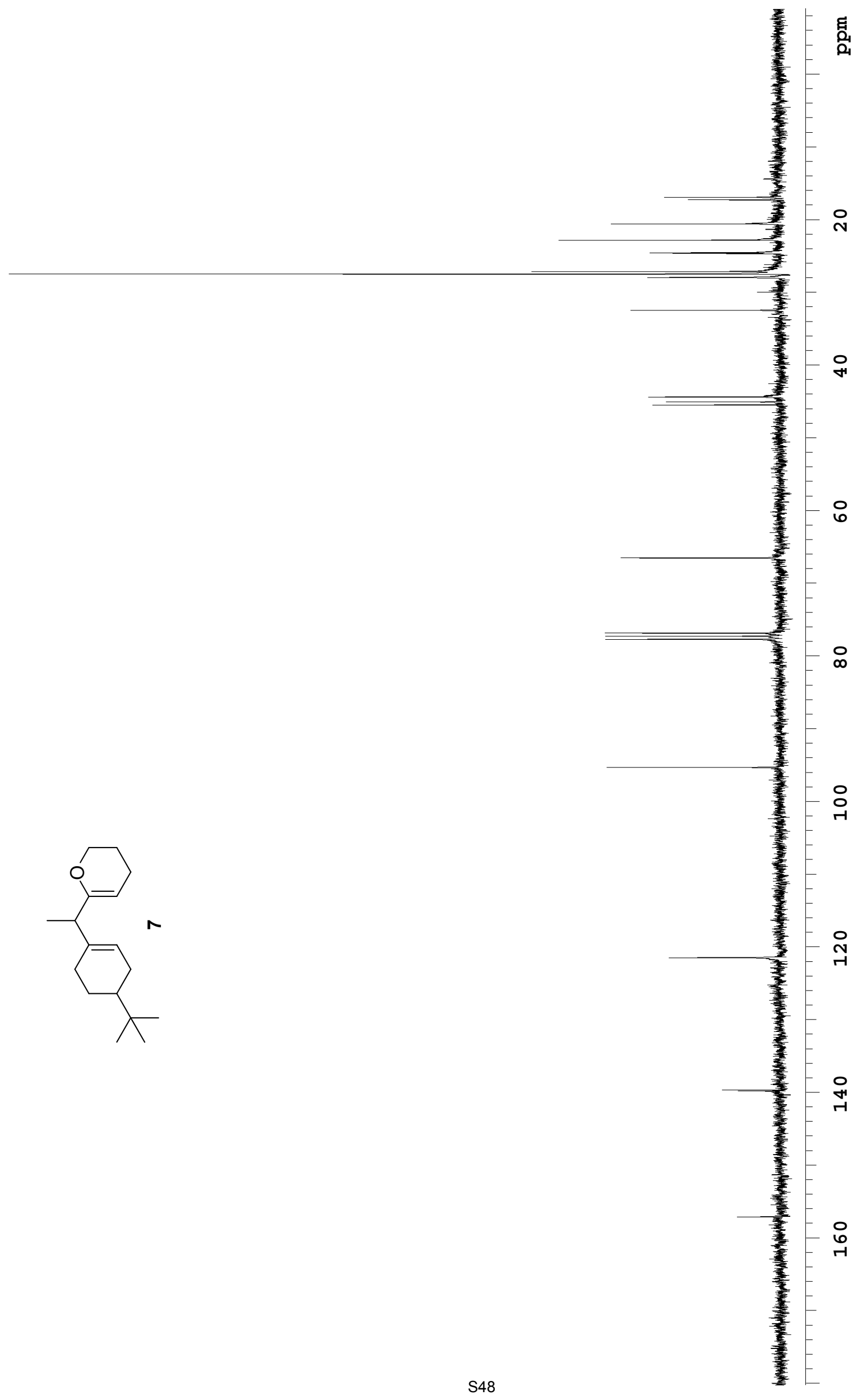

